\title{
A geomagnetic polarity stratigraphy for the Middle and Upper Ordovician
}

2

\author{
Mark W. Hounslow ${ }^{1}$, Samuel E. Harris ${ }^{2}$, Krystian Wójcik ${ }^{3}$, Jerzy Nawrocki ${ }^{4}$, Kenneth T. \\ Ratcliffe $^{5}$, Nigel H. Woodcock ${ }^{6}$, Paul Montgomery ${ }^{7}$ \\ 1. Lancaster Environment Centre, Lancaster University, Lancaster, UK. and Earth, \\ Ocean and Ecological Sciences, Univ. of Liverpool, Jane Herdman Building, \\ Liverpool, UK. (mark.w.hounslow@gmail.com :correspondant)
}

2. School of Archaeological and Forensic Sciences, University of Bradford, Bradford, BD7 1DP, UK (samh128@hotmail.com)

3. Państwowy Instytut Geologiczny - Państwowy Instytut Badawczy ul. Rakowiecka 4, 00-975 Warszawa, Poland (kwoj@pgi.gov.pl)

4. Faculty of Earth Sciences and Spatial Management, Maria Curie-Skłodowska University in Lublin, Al. Kraśnicka 2cf, 20-718 Lublin, Poland (jnaw @pgi.gov.pl)

5. Chemostrat Ltd, Buttington, Welshpool, UK (kenratcliffe@ chemostrat.com)

6. Department of Earth Sciences, University of Cambridge, Cambridge, CB2 3EQ, UK. (nhw1@cam.ac.uk)

7. Chevron upstream, Aberdeen, UK. (pmontgomery@ chevron.com)

\section{Abstract}

Magnetostratigraphic studies of the Ordovician provide evidence for the nature of coremantle boundary interactions, and provide means for dating and correlation across differing environmental regimes. We provide new magnetostratigraphic data from the Middle and Upper Ordovician, compiling this into a polarity chronostratigraphic scale for the Dapingian to Hirnantian interval. The new data are derived from the Backside Beck and Cheney Longville sections in Britain, the Mójcza section in Poland and two cores from Poland and Lithuania. The chronology is provided by existing biostratigraphy, principally based on chitinozoans and conodonts for the Ordovician. Correlations between sections are supported by carbon isotope stratigraphy linked to Baltic isotopic zonations, along with lithological and local magnetic susceptibility correlations in Polish cores. The palaeomagnetic signal is carried by both haematite and magnetite, with haematite dominating in red-coloured lithologies (marls and limestones) and magnetite in non-red mudstones and limestones. A positive reversal test (class $\mathrm{C}$ ) in the Cheney Longville section and positive fold tests in the Backside Beck section provide validation of the isolation of a primary palaeomagnetic signal. Palaeomagnetic directions from cores were re-oriented using Kiaman-age and Brunhes overprints. These new datasets in combination with existing Middle Ordovician data provides a near-complete magnetic polarity chronostratigraphic scale through the Middle and Upper Ordovician. Brief normal-polarity magnetozones extend well into the later parts of what has been considered the Moyero Superchron, which started in the late Tremadocian. Reversal frequencies for the mid and late Ordovician are 1.7 and $1.5 \mathrm{Myr}^{-1}$ respectively, although that for the late Ordovician may be an underestimate.

Keywords: Magnetostratigraphy, Moyero, superchron, palaeomagnetic, chronostratigraphy, reversal frequency 


\section{Introduction}

A geomagnetic polarity timescale (GPTS) for the Ordovician has a number of important uses, such as improved understanding of polarity reversal rates and their reflection of coremantle boundary interactions on geodynamo behaviour (Biggin et al., 2012; Hounslow et al., 2018), as well as providing a means of high resolution stratigraphic correlation to aid chronostratigraphy. Initial attempts to construct an Ordovician GPTS were in the 1960's and 1970's, based around sections from the Siberian Platform (Khramov and Rodionov, 1980; see discussion in Pavlov and Gallet 2020). However, the methods used to demagnetise samples were basic and poorly documented, and often in these studies are insufficiently related to other stratigraphic proxies (Pavlov et al., 2008; Trench et al., 1991). In addition, the widespread nature of Siberian re-magnetisation by intrusions or burial events likely compromised results from these early studies (Rodionov and Gurevich, 2010). Studies using modern demagnetisation techniques (Trench et al., 1991; Pavlov and Gallet, 2005, 2020; Grappione et al., 2017; Rodionov, 2016; Kolesov, 2007) have improved our knowledge of Lower and Middle Ordovician geomagnetic polarity. However, the polarity succession in the Upper Ordovician is largely unknown, with only polarity bias-type data, based on a few conventional palaeomagnetic studies (Trench et al., 1991; Algeo, 1996; Pavlov and Gallet, 2020). Existing Middle Ordovician magnetostratigraphic data is from sediment sections in Sweden, Estonia, NE Russia and the USA (Farr et al., 1993; Torsvik et al., 1995; Gallet and Pavlov, 1996, Pavlov and Gallet, 2005, Pavlov et al., 2012; Grappione et al., 2017).

This work provides the first magnetostratigraphic data from the later parts of the Ordovician, using five sections in the Upper Ordovician. In Britain, this uses sections at Backside Beck in the Howgill Fells (northern England) through the late Katian to the Ordovician-Silurian boundary, along with a Katian section in Shropshire at Cheney Longville (Fig. 1). From Poland, we describe data from the Sandbian to late Katian section at Mójcza from the Holy Cross Mountains. We also detail Middle to Upper Ordovician data from the Grabowiec-6 core in Poland, and Core-A from Lithuania (Fig. 1). The data from Core-A provides a template onto which other data can be related. These data are age constrained with existing graptolite, chitinozoan and conodont biostratigraphy and some new carbon isotope stratigraphy. We integrate these new data and existing datasets to yield a detailed polarity timescale from the Middle Ordovician through to the Hirnantian- Rhuddanian boundary, which joins that from the Llandovery of Hounslow et al. (inpress).

\section{Methods}

Palaeomagnetic samples from the sections were collected using hand samples, oriented with a magnetic compass. Cubic specimens were cut from the hand samples using a circular saw. Samples from Polish and Lithuanian cores were predominantly drill plugs.

Outcrops in the Ordovician at Backside Beck are spread discontinuously over ca. $300 \mathrm{~m}$, mostly in the bed of the stream, so the Ordovician samples were located on the ground using a combination of GPS, tape- measurements and map work to produce the composite stratigraphy, based around converting sample locations to stratigraphic position using 
bedding dips. Bedding dips in the Ordovician section are $12-47^{\circ}$ to the north. The precise sample positions are in the supplementary information (SI) Figs. S2 and S3. Only reconnaissance palaeomagnetic sampling of the Upper Ordovician was undertaken at Backside Beck, with most palaeomagnetic effort focussed on the Silurian, described in Hounslow et al. (inpress).

Sample measurements from Cheney Longville, Backside Beck, Core-A and Grabowiec-6 were performed at Lancaster, and those from the Mójcza section in Warsaw. At Lancaster measurements of Natural Remanent Magnetisation (NRM) were made using a CCL 3-axis cryogenic magnetometer (noise level $\sim 2 \mu \mathrm{A} / \mathrm{m}$, four determinations per orthogonal axis), using three specimen positions, from which the magnetisation variance was determined. Some specimens from Core-A were measured on a 2G Enterprises RAPID (noise level $\sim 0.5$ $\mu \mathrm{A} / \mathrm{m}$ ). Specimens were housed in Mu-metal boxes with an ambient magnetic field $<10 \mathrm{nT}$ at all times, other than when being measured or demagnetised. In Warsaw the NRM remanence was measured with an AGICO JR6A spinner magnetometer (noise level $\sim 10 \mu \mathrm{A} / \mathrm{m}$ ).

One to three specimens from each sample were treated to stepwise thermal demagnetisation, in $25-50^{\circ} \mathrm{C}$ steps up to $700^{\circ} \mathrm{C}$. Low frequency magnetic susceptibility $\left(\mathrm{K}_{\mathrm{lf}}\right)$ was monitored after heating stages, measured using a Bartington MS2B sensor to assess thermal alteration. Certain specimens from all sections, were treated with a combination of thermal and alternating field (AF) demagnetisation; the latter mostly conducted using a Molspin tumbling AF demagnetiser at Lancaster and Warsaw (or for a few static axis-AF on the RAPID, with GRM correction using GM4Edit; Hounslow, 2019). This combined procedure was to better isolate the remanence in the non-red lithologies, some of which were subject to thermal alteration, which started $\sim 250-350^{\circ} \mathrm{C}$. Methods for isolation of characteristic remanent magnetisation (ChRM) and ChRM behaviour classification are further detailed in Hounslow et al. (inpress) and in the Supplementary Information (SI). In addition to fold and reversal tests, we also use the mean VGP A95 $\min$ and A95 $\max$ thresholds of Deenen et al. (2011) to express the likely capture of secular variation in the directional datasets.

Using a representative sub-set of specimens, progressive isothermal remanent magnetisation (IRM) acquired in fields up to 1.8T, and anhysteretic remanent magnetisation (ARM) were applied to investigate the magnetic mineralogy (methods in Walden 1999). The IRM and ARM was measured using Molspin or JR6 spinner magnetometers. The anisotropy of magnetic susceptibility (AMS) was measured on selected specimens from Backside Beck, and Grabowiec-6 using an Agico KLY3S Kappameter, to assess the impact of tectonic fabric formation (Tarling and Hrouda, 1993).

For Core A and Grabowiec-6, surface magnetic susceptibility ( $\left.\mathrm{K}_{\text {surf }}\right)$ was measured using a Bartington Ltd MS2K surface probe (on flat-sectioned core surface), to assist sub-division of lithostratigraphy and inter-well correlation. Mass specific magnetic susceptibility was measured on a Bartington MS2B probe (at $0.47 \mathrm{kHz}$ ) to give $\chi_{\text {If }}$ in $\mathrm{m}^{3} / \mathrm{kg}$. At Backside Beck, magnetic susceptibility was also measured (average of 2-4 repeats) using a Bartington MS2F field probe, cross calibrated to 39 hand specimens (measured on the MS2B) to allow the 
124 specimen-based dataset from the MS2B probe to be joined to that from the MS2F field probe 125 in units of $\mathrm{m}^{3} / \mathrm{kg}$.

126 Organic carbon isotopes $\left(\delta^{13} \mathrm{C}_{\text {org }}\right)$ for Backside Beck, Cheney-Longville and Core-A are 127 given here, along with carbonate carbon isotope data for Core-A and Mójcza (see SI Tables

$128 \mathrm{~S} 1, \mathrm{~S} 2$ ). Some of these were measured at Lancaster, but isotope data from Core-A and some 129 samples from Backside Beck used methods in Sullivan et al. (2018). These additional data 130 were collected to improve the dating and correlation using carbon isotope stratigraphy 131 (Ainsaar et al., 2010; Cramer et al., 2011; Bergström et al., 2015).

132 Samples for $\delta^{13} \mathrm{C}_{\text {org }}$ measured at Lancaster were prepared by removing any carbonate 133 minerals by reacting powdered homogenised material with $6 \mathrm{~N} \mathrm{HCl}$ at $25^{\circ} \mathrm{C}$ for 24 hours 134 (Brodie et al., 2011). The residues were washed several times with distilled water to remove 135 any traces of acids. Residues were then oven-dried at $50^{\circ} \mathrm{C}$ for 24 hours and subsequently re136 powdered prior to $\delta^{13} \mathrm{C}_{\text {org }}$ isotope analysis. Decarbonated residues were weighed into tin 137 capsules and loaded into an auto-sampler connected to an Elementar Vario MICROcube, 138 from where they were dropped into the furnace at $950^{\circ} \mathrm{C}$. Produced gases were passed (under

$139 \mathrm{He}$ ) through chemical traps to remove sulphur, excess oxygen and water. Large sample 140 volumes could be used, so we could reliably measure $\delta^{13} \mathrm{C}_{\text {org }}$ down to around $0.02 \%$ total 141 organic carbon (\%TOC). Nitrogen was separated from $\mathrm{CO}_{2}$ by temperature programmed 142 desorption. The isotopic composition of the resultant purified $\mathrm{CO}_{2}$ was then measured using 143 an Isoprime100 Isotope mass spectrometer. Carbon isotope ratios are reported as delta values $144\left(\delta^{13} \mathrm{C}\right)$ in per mil relative to the international VPDB scale (standards used NBS-18 $=-5.014$ $145 \%$; LSVEC $=-46.6 \%$ oo. Analytical precision $(1 \sigma)$ is estimated to be better than $\pm 0.15 \%$ o for $146 \delta^{13} \mathrm{C}_{\text {org }}$ based on the replicate analysis of pure, well-mixed, organic compounds used as 147 laboratory calibration materials. Additional $\delta^{13} \mathrm{C}_{\text {org }}$ data shown for Grabowiec-6 and 148 Zwierzyniec-1 are from Sullivan et al. (2018).

\section{3.Geology and stratigraphy of sections and cores}

\section{$150 \quad 3.1$ Cheney-Longville Section, UK}

The section sampled is a road cutting $\left(52^{\circ} 28^{\prime} 03.7^{\prime \prime} \mathrm{N} ; 2^{\circ} 51^{\prime} 47.4^{\prime \prime} \mathrm{W}\right.$; elevation $\left.154 \mathrm{~m}\right)$ on the A489 in the classic area of the Caradoc Series in the Onny Valley in Shropshire, east of the Church Stretton Fault (SI Fig. S1b). Conodont alteration indices in the Ordovician east of the Church Stretton fault are low at around 1.5 (Aldridge, 1986). The Onny Valley strata have been extensively described for their shelly faunas, conodonts and chitinozoans (Dean, 1958, Hurst, 1979, Savage and Bassett, 1985; Rushton et al., 2000; Vandenbroucke et al., 2009). Since the 1970's when the road cuts were made, they have become increasingly vegetated, and in 2014 only around $20 \mathrm{~m}$ of the lower part of the Cheney-Longville Fm (grid reference SO 42028570 to 4208 8566) was suitably exposed for magnetostratigraphic sampling (Fig. 2 ). The sampled section comprises interbedded brownish sandstones (partly hummocky cross-bedded) and silty and sandy mudstones, with a limestone bed in the uppermost part of section. This unit was deposited in an inner shelf environment (Brenchley and Newall, 1982). Our sampled section starts ca. $41 \mathrm{~m}$ above the base of the formation within the Woolstonian substage (lower part of the British Cheneyan Stage). This is part of the succession between 
ca. 291-311 $\mathrm{m}$ in the Onny Valley succession, as summarised by Hannigan and Brookfield (2013). The Woolstonian and Cheneyan are some $140 \mathrm{~m}$ and $200 \mathrm{~m}$ thick in the Onny Valley, so the sampled section starts $\sim 51 \%$ and $\sim 36 \%$ through the Woolstonian and Cheneyan respectively. Chitinozoans from the Onny Valley sections indicate the section falls within the lower part of the Spinachitina cervicornis Biozone because of the distribution of the morphologically similar species Spinachitina multiradiata found in the Onny Valley sections (Vandenbroucke et al., 2009). In Baltoscandian regional stages the S. cervicornis Biozone ranges through the upper Haljala, Keila and lower Oandu stages (Vandenbroucke et al., 2009), but based on chitinozoan associations, the Woolstonian may equate to the mid parts of the Baltic Keila Substage (Vandenbroucke, 2008). $\delta^{13} \mathrm{C}_{\mathrm{org}}$ data from the section are broadly constant throughout the section between -27 to $-26 \%$ (apart from two probably spurious values less than $-28 \%$; Fig. 2e), indicating the section does not overlap with the Guttenberg carbon isotope excursion in the earliest Katian, within the Baltic Keila Stage (Ainsaar et al., 2010). Therefore in combination with the chitinozoan biostratigraphy, the section probably occupies the upper part of isotope zone BC5 in the Keila Stage (early Katian). This is confirmed by the chitinozoan distribution, when compared to graptolites seen in the Whitland section in South Wales where the S. cervicornis Biozone fauna is associated with graptolites from the clingani Biozone (Vandenbroucke, 2008). In addition, the shelly faunas of the Woolstonian Stage suggest correlation to the lower part of the graptolite clingani Biozone (Fortey et al., 1995).

\subsection{Mójcza section, Holy Cross Mountains, Poland}

The Mójcza section (5050'8.8"N; 2041'40.7"E; 251 m elevation) is located in the Kielce region of the Holy Cross Mountains and consists of condensed Middle to Upper Ordovician limestones of the Mójcza Formation, some $10 \mathrm{~m}$ thick (Dzik and Pisera, 1994; Trela, 1998, 2000, 2005, 2006a, b; Modliński and Szymański, 2001; Schätz et al., 2006; SI Fig. S1c). This is overlain by $1 \mathrm{~m}$ of ?Hirnantian claystones and siltstones and at least $3.5 \mathrm{~m}$ of Silurian graptolitic shales, assigned to the Prągowiec Beds (Fig. 3). Conodont alteration indices in the Mójcza Formation are low at 1.0 (Belka, 1990).

The Mójcza Formation formed on an isolated offshore carbonate platform showing strong phosphatisation, particularly in the latest Darriwilian and Sandbian (Trela, 2005). The limestones lack calcareous algae and reef-building corals, suggesting deposition below the photic zone, so the limestones are interpreted as deep water deposits, largely swept clear of major detrital inputs by oceanic currents (Trela, 1998). The section has a rich collection of conodonts, which allow a detailed zonation to be established (Dzik, 1978; 1994; Dzik and Pisera, 1994) from the Eoplacognathus variabilis zone of the early Darriwilian to the $A$. ordovicicus of the late Katian. A major hiatus occurs in the Darriwilian where the conodont E. suecicus Biozone is missing (Dzik and Pisera, 1994), although a number of hardgrounds also occur in the younger part of the formation, also indicating possible missing intervals (Trela, 2005), as might be expected in this highly condensed limestone. A bentonitic marker bed occurs in the upper part of the Pygodus anserinus Biozone near the Darriwilian-Sandbian boundary. The lower part of the section was previously sampled for magnetostratigraphy by 
206 Schätz et al. (2006), which we have extended into the upper part of the section and the newly

207 excavated overlying Silurian (Fig. 3).

Above the study interval of Schätz et al. (2006) are medium- to thick-bedded limestones, and thin-bedded brown to yellow argillaceous limestones and overlying marls and calcareous claystones with a sharp, erosional base. This interval forms the topmost part of the Mójcza

211 Formation (Trela, 2006a, b) and belongs to the upper superbus and ordovicicus conodont

212 biozones (Dzik and Pisera, 1994; Fig. 3). These limestones and marls are represented by ostracod packstones to wackestones with abraded and crushed remains of trilobite fragments, and scarce brachiopod and mollusc shells, deposited in calm-water conditions (Trela, 1998).

The topmost part of the Ordovician in the Mójcza section is formed by greenish-grey claystones and siltstones with one thin intercalation of sandstone, corresponding to the Zalesie Formation sensu Trela (2006a, b). This can be related to the sea-level drop during the Hirnantian, although there is no biostratigraphic evidence of age. Above this is a succession of Silurian graptolitic shales and siltstones with carbonate concretions and Odontopleura trilobites indicating correspondence to the Prągowiec Beds (Tomczyk, 1962; Malec, 2006). The stratigraphic range of these beds in the HCM is from uppermost Sheinwoodian graptolite rigidus Biozone to the Ludfordian leintwardinensis Biozone (Tomczyk, 1962; Tomczykowa and Tomczyk, 1981; Tomczykowa, 1988; Malec, 2006). As a consequence, the major stratigraphic gap at the Ordovician and Silurian boundary in the Mójcza section includes at least the Llandovery and almost all the Sheinwoodian. The origin of this hiatus, either through no deposition/erosion or tectonic reduction, is uncertain.

A $\delta^{13} C_{\text {carb }}$ stratigraphy is available for the bulk of the Mójcza Formation (Trela, 2000), with overlapping data collected here (Fig. 3e), which broadly agree with the details of Trela (2000). In our sampled interval $\delta^{13} \mathrm{C}_{\text {carb }}$ data show a general upwards trend in the Mójcza Fm from $-1 \%$ oto $1 \%$ (Fig. 3e). This range is similar to that from lower in the section which varies from ca. -2 to $1 \%$ (Trela, 2000).

\subsection{Core A, Livonian Tongue, Lithuania}

Core-A is from the Livonian Tongue, an early Palaeozoic sag basin that extends across western Lithuanian and Latvia and southern Estonia, and was an extension of the Central Baltic Basin to the SW (Modliński et al., 1999; Paškevičius, 2007; Dronov et al., 2011;

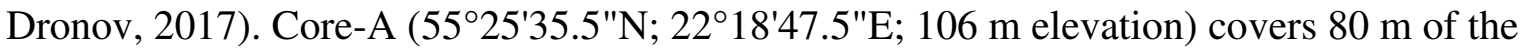
Ordovician and $15 \mathrm{~m}$ of the early Llandovery. A major unconformity separates the Ordovician from the underlying Cambrian (Fig. 4). Bedding dips are near zero and thermal alteration shown by regional conodont alteration indices are around 1.0 (Nehring-Lefeld et al., 1997).

The lithostratigraphy of the Ordovician in the Livonian Tongue is well established (Lazauskiene et al., 2003; Hints et al., 2005; Dronov et al., 2011; Meidla et al., 2014), which allows a sub-division of the core into a detailed lithostratigraphy (Fig. 4). This lithostratigraphy can be related to the Baltic regional stages (Männil and Meidla, 1994), which have a detailed conodont, graptolite and chitinozoan biostratigraphy (Nõlvak et al., 2006; Meidla et al., 2014). This is supplemented by a detailed carbon isotope sequence 
247 stratigraphy and locally an ash bed stratigraphy (Ainsaar et al., 2010; Harris et al., 2004;

248 Lazauskiene et al., 2003; Kiipli et al., 2009). The surface magnetic susceptibility ( $\left.\mathrm{K}_{\text {surf }}\right)$ to a

249 large extent inversely reflects the carbonate content of the cores with lows in carbonate-rich

250 intervals (e.g. Saldus Fm) and highs in mudstone rich intervals, particularly if they are red-

251 coloured like in the Kriukai Fm of the Vokhov Stage (Fig. 4). A high in $\mathrm{K}_{\text {surf }}$ at $41.4 \mathrm{~m}$ relates

252 to the peak of Sandbian organic-rich shale 'kukersite' accumulation in the Kukruse Stage

253 (Kiipli et al., 2010). A complex of bentonites in the Adza Fm at $38.7 \mathrm{~m}$ (including the

254 Kinnekulle-K bentonite, Kiipli et al., 2009; Fig. 4) is marked by a broad low in $\mathrm{K}_{\text {surf }}$, like in

255 the Vollen section near Oslo (Svensen et al., 2015). The fragmentary carbon isotope

256 stratigraphy in combination with the lithostratigraphy allows some of the carbon isotope

257 zones of Ainsaar et al. (2010) from the Jurmala R-1 core ( 150 km to the NNE) to be

258 correlated to Core-A. This assumes the $\delta^{13} \mathrm{C}_{\text {carb }}$ changes are largely synchronous, but which is

259 not necessarily the case for Baltican lithostratigraphic boundaries, which can be diachronous

260 (Ainsaar et al., 2010; Hints et al., 2014). The upwards decline in $\delta^{13} \mathrm{C}_{\text {carb }}$ seen through the

261 Saldus Fm and the low at around depth $1.5 \mathrm{~m}$ indicates the equivalent of the terminal part of

262 the persculptus Biozone is present in the core (Gorjan et al., 2012), truncated by the

263 unconformity at the base of the overlying Remte Fm (Fig. 4), whose basal age is late

264 Rhuddanian (Hounslow et al., inpress).

\subsection{Grabowiec-6 Core, Lublin slope, Poland}

The Grabowiec-6 well (Fig. 1 5057'5.2"N; 2325'56.8"E; 209 m elevation) cored Katian to late Ludfordian (Sullivan et al., 2018) horizontally bedded units. Only the $23.8 \mathrm{~m}$ of Upper Ordovician carbonates beginning at $3793.1 \mathrm{~m}$ are described here (Fig. 5), the overlying Telchyian is described by Hounslow et al. (inpress). Conodont alteration indices are around 3-4 (Nehring-Lefeld et al., 1997). The Ordovician in the core can be divided into two parts by a reddened hardground surface at $3797.8 \mathrm{~m}$, which has a substantial $\mathrm{K}_{\text {surf }}$ spike (Fig. 5c). The limestone above this surface is barren, but below, it contains chitinozoans and graptolites. The graptolite Lasiograptus harknessi at $3801 \mathrm{~m}$ has a wide range through the gracilis, foliaceus and clingani biozones of Scania (Pålsson, 2001), indicating possible Sandbian-early Katian strata. The chitinozoan Lagenochitina baltica between $3801.1 \mathrm{~m}$ and $3815.0 \mathrm{~m}$ is probably the most diagnostic for age (Fig. 5c). In Baltic successions this first appears near the base of the Fungochitina fungiflormis Zone (at base of the Baltic Rakvere Stage, mid parts of the conodont superbus Biozone; Kiipli et al., 2014), and disappears near the top of the Tanuchitina bergstroemi Zone (early Pirgu Stage, mid ordovicicus Biozone at around the

280 basal graptolite complanatus Biozone; Nõlvak and Grahn, 1993). In Avalonian successions, the first occurrence of L. baltica is often used as a proxy for the Fungochitina spinifera Biozone, with an upper range through the T. bergstroemi Biozone (through the British Onnnian, Pusgillian and into the Cautleyan stages; Vandenbroucke, 2008, Vandenbroucke et al., 2013). Additional age constraints can be obtained by correlation to the Zwierzyniec-1 well, $25.7 \mathrm{~km}$ to the southwest (Fig. 5a,b). The prominent double peaked in $\mathrm{K}_{\text {surf }}$ can be seen in both wells (3801.5- 3795.4 $\mathrm{m}$ in Grabowiec-6 and 3011.5-3002 $\mathrm{m}$ in Zwierzyniec-1), with the intervening low in $\mathrm{K}_{\text {surf }}$ related to an increase in carbonate content, shown by a prominent low in $\mathrm{Al} \%$ (Fig. 5b). This interval is also enriched in the Fe/Si ratio and has elevated NRM intensity (Fig. 5b,c), which is related to the more oxic nature of limestones over this interval. 
290 Lower in both cores smaller amplitude modulation of the $\mathrm{K}_{\text {surf }}$ signal along with sharp low

291 troughs (high carbonate contents) in $\mathrm{K}_{\text {surf }}$ tentatively allow a more detailed correlation that is

292 consistent with the distribution of the chitinozoan Belonechitina hirsuta complex. In Baltic

293 successions the chitinozoan Spinachitina multiradiata is a component of the Lagenochitina

294 dalbyensis and Sp. cervicornis biozones (Nõlvak and Grahn, 1993; Grahn and Nõlvak, 2007),

295 having a range through upper foliaceous and lower clingani biozones, suggesting a level near

296 the Sandbian-Katian boundary in the bottom of the Zwierzyniec-1 core (Fig. 5a). This and the

297 overlying biostratigraphy (Sullivan et al., 2018) is consistent with the $\delta^{13} C_{\text {org }}$ excursions in

298 Zwierzyniec-1, which suggest the Rakvere, Saunja, Moe and Paroveja excursions of Ainsaar

299 et al. (2010) are present. These correlation relationships suggest the barren unit above 3797.8

$300 \mathrm{~m}$ in Grabowiec-6 represents the early part of the Hirnantian (Fig. 5c).

301 These ages are supported by the nearby (15 km to NW) Łopiennik IG-1 well, where the

$30217.5 \mathrm{~m}$ of the uppermost Ordovician, Tyśmienica Formation overlies the Kodeniec Formation

303 (Modliński and Szymański, 2008). The Kodeniec Formation is 4-5 m of grey and red-

304 brownish marly and organodetritic limestones (Modliński and Szymański, 2008, 2012;

305 Drygant et al., 2006) which is lithologically similar to the $3799.5-3796 \mathrm{~m}$ interval in

306 Grabowiec-6. The Tyśmienica Formation contains trilobites and brachiopods with

307 Mucronaspis sp., ?Proteus sp., ?Platymenta cf. polonica, Eostropheodonta sp., Plactatrypa

308 sp., and Orbiculoidea sp. indicating the Hirnantian (op. cit.). Therefore the interval $3799.5 \mathrm{~m}$

309 to top most Ordovician in Grabowiec-6 likely correlates to the Kodeniec and overlying

310 Tyśmienica formations in Łopiennik IG-1. Underlying the Kodeniec Formation in wells

311 Białopole IG-1 (20 km to NE) and Łopiennik IG-1 is 53-57 m of dark claystones with

312 intercalations of mudstones, marls and marly limestones of the Udal Formation. The middle

313 part of which has a fauna of D. clingani, Amplexograptus vasae, Climacograptus bicornis,

314 Orthograptus calcaratus tenuicornis (Modliński and Szymański, 2008, 2012) indicating the

315 clingani Biozone, and is lithologically much like the cored interval in Grabowiec-6 below

$3163799.5 \mathrm{~m}$. These data indicate the Ordovician in Grabowiec-6 is younger than the Cheney

317 Longville section, but overlaps in age with the mid part of the Mójcza section. Consequently,

318 the hiatus at $3793.18 \mathrm{~m}$ in Grabowiec-6 has most of the Llandovery and probably late

319 Hirnantian missing (Sullivan et al., 2018).

\section{$320 \quad 3.5$ Backside Beck section, Lake District, UK}

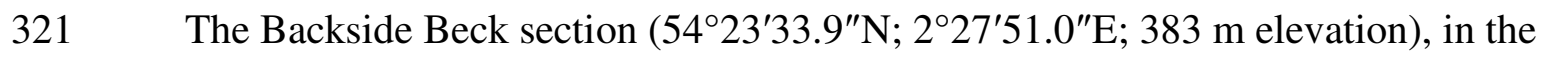

322 Westerdale inlier of the Howgill Fells, provides one of the most continuous sections in

323 England through the Upper Ordovician and Llandovery (SI Fig. S1a), and is also in the type

324 area of the British Ashgill Series (Ingham and Wright, 1970). In the section a significant N-S

325 striking fault cuts the Upper Ordovician Cautley Volcanic Member, just below the base of the

326 studied section (Fig. 5 and SI Figs. S2, S3). Conodont alteration indices in the Upper

327 Ordovician of the central Lake District to the west are around 5 (Bergström, 1980), although

328 in the Howgill Fells may be less thermally mature than this (Oliver, 1988). Although thermal

329 alteration is high, this region contains one of the few good quality palaeomagnetic datasets

330 from European Silurian sediments (Channell et al., 1993), so was investigated in more detail. 
The sampled part of the Backside Beck section (Fig. 6) begins in bedded, pink to buff, rhyolitic, vitric tuffs of the Cautley Volcanic Member. The water lain tuff units grade into, and are interbedded with, blue-grey, calcareous mudstones containing light grey calcareous nodules typical of the enclosing Cautley Mudstone Formation. This upper part of the Cautley Mudstone Formation above the main volcanic interval ( -60 to $-35 \mathrm{~m}$; Fig. 5), and below the Cystoid Limestone Member was assigned to trilobite zone 7 (late Rawtheyan) by Ingham (1966). Rickards $(2002,2004)$ re-assessed the graptolite faunas from Ingham's zones and suggested that Ingham's Zone 6 fauna (mid Rawtheyan ) belongs to the linearis Biozone, hinting that the slightly different graptolite assemblage in trilobite Zone 7 may be indicative of a transition into the complanatus Biozone (earliest Rawtheyan; late Katian; Zalasiewicz et al., 2009). This implied that the main body of the complanatus and anceps biozones, and any Hirnantian must be restricted to the overlying beds (i.e. uppermost part of Cautley Mudstone through Ashgill formations). The chitinozoan Bursachitina umbilicata Biozone occurs in the younger part of the Cautley Mudstone (Vandenbroucke et al., 2005; Vandenbroucke, 2008). Within this unit chitinozoan Ancyrochitina merga allows correlation to the northern Gondwana A. merga Biozone, the terminal chitinozoan zone of the Katian, which conflicts with the older age suggested by the 'transitional' complanatus Biozone interpretation of Rickards (2002). This younger age for the upper part of the Cautley Mudstone Fm is consistent, with beds assigned to Ingham's zone 7 at Girvan which contain Paraorthograptus pacificus, the index species of the upper subzone of the anceps Biozone of the latest Katian (Floyd et al., 1999; Zalasiewicz et al., 2009).

A 2 m thick muddy limestone; the Cystoid Limestone Member, marks the base of the Ashgill Formation (Fig. 6). In the nearby Taythes Inlier, the volcanic member and two shelly faunal zones are missing below this limestone (Ingham, 1966), but this hiatus is not evident at Backside Beck. The main Ashgill Formation comprises about $70 \mathrm{~m}$ of blue-grey mudstones lacking the calcareous nodules of the Cautley Mudstone Formation (Fig. 6). Apart from the benthic shelly fauna in the Cystoid Limestone, the Ashgill Formation is sparsely fossiliferous and restricted to one trilobite species (Mu. mucronata) and three brachiopod species (e.g. Eostropheodonta, Dalmanella, Plectatrypa), and Hirnantia cf. sagittifera (Ingham, 1966). The bulk of this 'Hirnantian-type' shelly fauna comes from the upper part of the Ashgill Fm, but over a wide area of the Howgill Fells (Ingham, 1966). The Ashgill Fm is barren of graptolites and chitinozoans (Rickards 2002; Vandenbroucke et al., 2005). A sandy mudstone $12.2 \mathrm{~m}$ below the top of the formation, may correlate with conglomerates elsewhere in the Cautley inliers and with the Wharfe Conglomerate Member from the Craven inliers (Rickards and Woodcock 2005) probably representing a sea level low- stand.

The base of the overlying Skelgill Formation is marked by a 1.0 metre thick limestone (at Backside Beck), the Spengill Member (Kneller et al., 1994), which is the 'basal beds' of Rickards (1970, 1988) and earlier authors (Fig. 6). In Lake District sections to the west, this member contains persculptus Biozone graptolites (Hutt, 1974) and the distinctive lowdiversity Hirnantia shelly fauna including Hirnantia sagittifera (Scott and Kneller, 1990). The Spengill Member is therefore Hirnantian rather than Llandovery in age and is overlain by black shales starting in the acuminatus Biozone. 
The $\delta^{13} \mathrm{C}_{\text {org }}$ shows a decline through the Ashgill Fm to more negative values from a high in $\delta^{13} \mathrm{C}_{\text {org }}$ of ca $-28 \%$ at around the level of the Cystoid Limestone Mbr, with a low in $\delta^{13} \mathrm{C}_{\text {org }}$ in the Ashgill Fm at ca. $60 \mathrm{~m}$ (Fig. 6e). Above this there is some fluctuation to a second high of ca. $-28.3 \%$, in the uppermost two samples from the Spengill Mbr. The $\delta^{13} \mathrm{C}_{\text {org }}$ changes beginning around $60 \mathrm{~m}$ and into the Spengill Mbr are inferred to be the initial part of the rising limb of the Hirnantian isotope excursion (HICE), with the corresponding underlying low in $\delta^{13} \mathrm{C}$ seen in Baltic sections, close to the base of the Porkuni Stage (Jurmala R-1; Fig. 4) in the latest Katian (Ainsaar et al., 2010; Bergström et al., 2015). The increasingly more positive values downwards through the Ashgill $\mathrm{Fm}$ are probably part of isotope zone BC15 in the underlying upper part of the Baltic Pirgu Stage (Fig. 4) of latest Katian age. This correlation is compatible with the Hirnantian faunas from the upper Ashgill Fm and Spengill Mbr.

\section{Magnetic results.}

\subsection{Magnetic mineralogy}

The magnetic mineralogy of samples from the sections and cores range from hard to soft coercivity behaviour, with higher coercivity minerals (haematite or goethite) seen by nonsaturation in an IRM field of $300 \mathrm{mT}$ (Fig. 7), and remanent coercivities $\left(\mathrm{H}_{\mathrm{cr}}\right)>200 \mathrm{mT}$ (SI Fig. S4). Reddish-and brownish coloured samples at Mójcza and Core-A have $>80 \%$ of IRM acquisition above $200 \mathrm{mT}$ and $\mathrm{H}_{\mathrm{cr}}>280 \mathrm{mT}$ (Figs. 7a,b; SI Fig. S4). The hard ferrimagnetic mineral in most of these samples is haematite as shown by the resistance of the NRM to thermal demagnetisation (see later).

Grey-coloured samples from Backside Beck and Grabowiec-6 have some of the softest behaviour $\left(\mathrm{H}_{\mathrm{cr}}<50 \mathrm{mT}\right.$; SI Fig. S4), but with most samples tested having 10-20\% of IRM acquisition above $200 \mathrm{mT}$ (Figs. 7c,d). Behaviours intermediate between these hard and soft end members are found in most sections in the non-red lithologies. The relative consistency of the $\mathrm{H}_{\mathrm{cr}}$ and $\mathrm{SIRM}_{1 \mathrm{~T}} / \chi_{\mathrm{ARM}}$ values in those samples with softer coercivity behaviour, suggest a similar mineralogy in most of the sections and cores (SI Fig. S4). Using data from Peters and Dekkers (2003) suggests this is most likely magnetite, with magnetic particle sizes $<0.1$ $\mu \mathrm{m}$ in size (See Fig. S4).

\subsection{Palaeomagnetic and magnetostratigraphic results}

\subsubsection{Cheney-Longville section}

The palaeomagnetic specimens responded best to thermal demagnetisation to round $350^{\circ} \mathrm{C}$ to $400^{\circ} \mathrm{C}$, followed by $\mathrm{AF}$ demagnetisation (Fig. $8 \mathrm{~b}, \mathrm{c}$ ). There are no systematic changes in NRM intensity (mean $=0.48 \mathrm{~mA} / \mathrm{m}$ ) or magnetic susceptibility (mean $\left.=23 \times 10^{-6} \mathrm{SI}\right)$ in the section (Fig. 2). A low stability component typically dominates the NRM, up to around $200^{\circ} \mathrm{C}$ to $250^{\circ} \mathrm{C}$ with some $80 \%$ of the NRM intensity composed of this component (Fig. $8 b, c)$. This well-defined component (mean of $359,+75, \alpha_{95}=3.1$; SI Fig. S6) is interpreted as a primarily a Brunhes component (geocentric axial dipole inclination at site $=69^{\circ}$ ). Intermediate stability components are dominated by a weak Kiaman-like component, along with fairly random composite directions that may be mixtures of Brunhes, Kiaman or ChRM 
413 directions (SI Fig. S6). The dual polarity ChRM (Fig. 9) is usually the highest stability

414 component (often through the origin), but in nine specimens is in the intermediate stability

415 range. In these specimens this may relate to the Kiaman-like component sometimes residing

416 in haematite. $82 \%$ of specimens contain evidence of ChRM polarity, with $59 \%$ of these being

417 line-fits (Fig. 2). Mean directions using either Fisher mean or the combined great circle

418 method pass reversal tests (Table 1; Fig. 9). Minor bedding dip divergence of $15-25^{\circ}$

419 precluded use of a fold test. The mean VGP, A95 is within the thresholds of Deenan et al.

420 (2011) indicating dispersion is within the secular variation range (Table 1). The section

421 polarity is dominantly reverse with three thin normal-polarity magnetozones and two further

422 tentative normal magnetozones (Fig. 2)

\subsubsection{Mójcza section}

Low stability (LT) components $\left(100-250^{\circ} \mathrm{C}\right.$ or to early AF range) are mostly Brunhes or composites of Brunhes and Kiaman, since some of the LT components are skewed to the south in geographic coordinates, due to component overlap with the Kiaman component (SI Fig. S6). In 9\% of specimens this component comprised the entire NRM. We did not find the randomly oriented low stability component identified by Schätz et al. (2006) that they assigned to a goethite remanence (Fig. 8d, e).

Mid-stability (MT) components are interpreted as mostly Kiaman, or a composite of ChRM and Kiaman components (steps from around $200^{\circ} \mathrm{C}$ into mid or high $\mathrm{AF}$ demagnetisation range). This is a post-tilting component (SI Fig. S6) that is the same as component-B identified by Schätz et al. (2006). Other MT components seem to be composite directions between the Kiaman component and the Brunhes or the Kiaman and the high temperature (HT) components (SI Fig. S6). The Kiaman overprints are strongly concentrated in the Ordovician part of the section, with the Silurian part of the section mostly having the intermediate stability Kiaman-Brunhes composite components. In $20 \%$ of specimens the MT component persisted until complete demagnetisation.

High stability components are interpreted as Ordovician and Silurian ChRMs (Fig. 9). Line fits through these components are few, since mostly this component is seen as, greatcircle trends toward the expected polarity (Fig. 3b). Schätz et al. (2006) found similar behaviour in the lower part of the section. The Wenlock age part of the section is dominated by great circle behaviours. The Upper Ordovician and the Pragowiec Beds parts of the section have quite different mean directions (Table 1).

Our Ordovician data fails the reversal test with reverse and normal $25^{\circ}$ apart, with a critical angle of $14^{\circ}$ (McFadden and McElhinney, 1990). However, the data of Schätz et al. (2006) from the lower part of the section passed a reversal test (class C). Bedding dips are not sufficiently different to enable a meaningful fold test. $65 \%$ of specimens contain evidence of ChRM polarity, with $31 \%$ of these being line-fits (Table 1; Fig. 3b). The mean VGP, A95 of both the Silurian and Ordovician parts of the section are within the thresholds of Deenan et al. (2011) indicating dispersion is consistent with capture of secular variation (Table 1)These data define five normal and three reverse-polarity magnetozones, with one and two tentative normal and reverse submagnetozones respectively (Fig. 3d). 


\subsubsection{Core-A, Lithuania}

Thermal demagnetisation to $250-340^{\circ} \mathrm{C}$ followed by $\mathrm{AF}$ demagnetisation, best suited samples from the Saldus Fm and some of the remaining Ordovician grey-coloured lithologies, whereas thermal demagnetisation to around $500-550^{\circ} \mathrm{C}$ worked best for Ordovician red-lithologies, and most of the paler limestones. Low temperature (LT) components extracted between the NRM and around 250 or $300^{\circ} \mathrm{C}$ are steep down-directed, and interpreted as largely a Brunhes age component (Fig. 8h,i,j). In a small proportion of samples, particularly from the upper parts of the core, the LT component is very steep and may be in part drilling-induced origin (De Wall and Worm, 2001). In most specimens, the LT component tends to dominate the magnetisation intensity, but with evidence of an additional dual polarity ChRM component remaining to the highest demagnetisation stages. The mean inclination of the LT component is $73^{\circ}\left(\alpha_{95}=2.4^{\circ}, \mathrm{n}=155\right.$ method of McFadden and Reid, (1982); expected geocentric axial dipole field inclination of $71^{\circ}$; Fig. 10e). The LT component was used to re-orient the core runs (e.g. Hailwood and Ding, 1995), and recover mean ChRM directions (Figs. 10f, g). The LT data from specimens in contiguous core runs were averaged to determine the mean azimuth, where possible. However, some $24 \%$ of ChRM specimen data could not be oriented using these methods, so both VGP latitude and inclination data is shown (Fig. 11d). No evidence for the presence of a Kiaman component was found in these samples, a feature also inferred by Grappone et al. (2017) in Middle Ordovician limestones from northern Estonia, although contrastingly Plado et al. (2010) identified Permo-Triassic re-magnetisations carried by haematite in Middle Ordovician limestones in northern Estonia.

$95 \%$ of specimens contained evidence of the ChRM, often in the mid to late stages of AF demagnetisation, or from around $300-400^{\circ} \mathrm{C}$ to the maximum thermal demagnetisation step, for thermally demagnetised specimens (Fig. 8h, i, j). $98 \%$ of specimens yielded a polarity interpretation, and $88 \%$ of these were s-class line fits (Fig. 11b), with the remaining 12\% interpreted as T-class great-circle trends, based on the re-orientation of the core (Figs. 10, 11). Mean inclination (and re-oriented mean directions) shows a systematic decline up though the core (Figs. 10g, 11d). Reversal tests (McFadden and McElhinney, 1990) are varied ranging from indeterminate to fail due to the larger than usual dispersion (Table 1), due to additional declination dispersion from re-orienting the core using the LT component (Fig. 10f). This additional dispersion has lead to larger A95 (Table 1) outside the usual secular variation thresholds of Deenan et al. (2011). The VGP latitude was determined using the mean direction from depths $80-30 \mathrm{~m}$ and $30-16 \mathrm{~m}$ (Silurian data above $0 \mathrm{~m}$ in Hounslow et al. inpress), due to the systematic difference in inclinations. These data define 10 normal and 11 reverse-polarity magnetozones, with 5 tentative single-specimen magnetozones (Fig. 11). The palaeomagnetic data from Core-A is the best quality of those we have studied here, in spite of the apparently larger ChRM dispersion due to the imperfect core re-oriented.

\subsubsection{Grabowiec-6 core}

Samples responded best to thermal demagnetisation to around $430^{\circ} \mathrm{C}$ followed by $\mathrm{AF}$ demagnetisation, or sometimes entirely thermal magnetisation (Fig. 8f,g). A low stability (component LT) component was isolated by thermal demagnetisation between 100 and 210- 
$250^{\circ} \mathrm{C}$. The mean of this component has a slightly steeper inclination $\left(73.5^{\circ} \alpha_{95}=2.0\right.$; McFadden and Reid, 1982) than the expected modern field at the core site (of $68^{\circ}$ ). The LT component is interpreted as predominantly a Brunhes age component. The intermediate, and often the high stability components are dominated by an often negative inclination component, which is often stable until the last stages of demagnetisation (Fig. 8f,g). Reorientation of the core runs using the LT component shows the largely SSW-directed nature of this component (Fig. 10a). This is interpreted as a Kiaman partial re-magnetisation, which is widespread in early Palaeozoic sediments in Poland and the East European Craton margins (Smethhurst and Khramov, 1992; Jelenska et al., 2005; Nawrocki, 2000). This Kiaman component in the specimens is very well defined, and when used to re-orient the core, indicates the LT component is scattered between the Brunhes field direction and the Kiaman component (Fig. 10b). We therefore used the better-defined Kiaman component to re-orient the specimens to assist in interpreting the behaviour of the Ordovician component. We used a mean Kiaman palaeopole (palaeopole at latitude $=-42.2^{\circ}$, longitude $=346^{\circ}$; giving an expected Kiaman field direction at the well site of $207^{\circ}, /-17^{\circ}$ ), based on 8 published studies from eastern Europe (SI Fig. S6). Data from specimens in contiguous core runs (Hailwood and Ding, 1995) were averaged to determine the mean azimuth for runs, where available.

$74 \%$ of specimens contained evidence of an additional magnetisation component at the highest demagnetisation stages, at AF demagnetisation $>60 \mathrm{mT}$ or thermal demagnetisation $>400^{\circ} \mathrm{C}$ (Fig. 12b). In $30 \%$ of these specimens (6 specimens), a ChRM line-fit direction could be extracted (Fig. 10c). In the remaining 14 specimens this component is shown as great circle trajectory trends (Figs. 10d; 12b) towards expected Ordovician normal and reversepolarity directions, defining four normal and three reverse-polarity magnetozones. (Fig. 12d). Great-circle trends were combined with the ChRM directions to define a mean direction and a palaeopole (Table 1). A95 larger (and close to upper range) than the secular variation thresholds of Deenen et al. (2011) is probably due to some additional declination dispersion from the less than perfect core re-orientation (Table 1). The AMS shows exclusively sedimentary type fabrics (See SI Fig. S5).

\subsubsection{Backside Beck section, UK}

The $\chi_{\mathrm{lf}}$ in the section broadly follows the formational units, with lows in the Cautley Mudstone Fm, which may reflect increased ash content in the mudstones from the upper part of the Cautley Mudstone Fm. The Ashgill Fm has largely consistent $\chi_{1 \mathrm{f}}$ values, with perhaps some variation, which is partly defined with the field probe data (Fig. 6a), but a decline in the uppermost Ashgill Fm, which presumably may be a reflection of the environmental changes heralding the Hirnantian. The magnetic susceptibility is primarily carried by paramagnetic minerals in the section (Hounslow et al., submitted), so the $\chi_{\mathrm{lf}}$ changes must be primarily reflecting Fe-silicate content. The largest $\chi_{\mathrm{lf}}$ are in the lower part of the Spengill Mbr (Fig. 6a).

Our reconnaissance palaeomagnetic sampling of the Ordovician at Backside Beck indicates some $62 \%$ of samples showed evidence of Ordovician polarity (Fig. 6b), the remainder were overprinted. Some $77 \%$ of these show great circle behaviour (T-class data; 
537 Fig. 6b). Ordovician samples show a dual polarity ChRM often seen by thermal

538 demagnetisation steps above $400^{\circ} \mathrm{C}$, or by $\mathrm{AF}$ demagnetisation above $40 \mathrm{mT}$ (Fig. 8a). The

539 palaeomagnetic behaviour of these is similar to the larger number of samples measured from

540 the overlying Silurian in the section by Hounslow et al. (inpress), and the interpretation of

541 overprint components does not differ (SI Fig. S7). Their data shows a low stability

542 components (often up to $200-400{ }^{\circ} \mathrm{C}$ ), which is a Brunhes-like component. Intermediate

543 stability components are either dual polarity Lower Devonian in age, or southerly directed

544 and shallow inclinations, with both up and downwards dipping directions, likely of Kiaman

545 (late Carboniferous) age, or composite in nature. Further palaeomagnetic details are in

546 Hounslow et al. (inpress) and the Ordovician data is compared to their data in SI Fig. S7. The

547 combined great circle mean suffers from too few samples to provide a sufficiently precise

548 directional mean (Table 1). However, the VGP A95 is within the thresholds of Deenen et al.

549 (2011) for the expected range of secular variation (Table 1). Fold tests are possible, but only

550 using the Ordovician and Silurian data combined (See SI Figs. S8, S10 to S13). The proportional and DC-fold tests indicate a positive fold test, with the $95 \%$ confidence intervals on unfolding including 100\% unfolding (Table 2). The McFadden fold test indicates that $100 \%$ unfolding is the most likely option for ChRM acquisition $\left(\mathrm{P}_{\mathrm{f}}>5 \%\right.$; Table 2). Channell et al. (1993) also obtained a positive regional fold test using data from the late Llandovery of this area.

The data tentatively define two normal and one reverse-polarity magnetozones, with one additional very tentative reverse submagnetozone at the section base (Fig. 6). The AMS data from the Ordovician shows a similar style to the overlying Silurian described in detail by Hounslow et al. (inpress), which shows evidence of some tectonic modification, shown by the $\mathrm{K}_{1}$ axes corresponding to the bedding-cleavage intersection, but also by more complex inverse-related fabrics, described in more detail by Hounslow et al. (inpress), with the Ordovician sample data in SI Fig. S9.

\section{3}

\section{Middle and Upper Ordovician geomagnetic polarity}

The higher quality of the magnetostratigraphic data from Core-A, along with the detailed lithostratigraphy of this core, linked to the Baltic regional stages provides a suitable template for the other Middle and Upper Ordovician magnetostratigraphic data. Other existing magnetostratigraphic datasets are from Sweden, Estonia and USA (Arkansas) in the Middle Ordovician (Farr et al., 1993; Torsvik et al., 1995, Grappione et al., 2017), more extensive data from Siberia (Pavlov and Gallet, 1998, 2005; Pavlov et al., 2012) and some data from Poland (Schätz et al., 2006). Gallet and Pavlov (1996) dismissed the data from Farr et al. (1993) due to an 'inversion' in the component stability, with a Kiaman component more stable than the inferred Ordovician component. Whilst this is unusual, similar behaviour from the Ukrainian Silurian is known (Jelenska et al., 2005), and the magnetostratigraphy seems repeatable from multiple sections, so the composite-section data from Farr et al. (1993) is used here in a tentative fashion.

Although the Siberian dataset is the largest, the Siberia regional stages are problematic to link to Baltican and international stages due to the endemic faunas (Dronov, 2013, 2017;

578 Sennikov et al., 2015). The best means to do this independently of the magnetostratigraphy is 
579 carbon isotope stratigraphy, supported by limited cosmopolitan biostratigraphic data and 580 sequence stratigraphy (Kanygin et al., 2010; Ainsaar et al., 2015). Two biostratigraphic tie 581 points in the Volginian and basal Chertovskian stages allows linkage of the Siberian sections 582 into the late Darriwilian- Sandbian interval (Dronov, 2017). The carbon isotope zones (BC1 583 to BC17) of Ainsaar et al. (2010) and their proposed equivalent isotope zones in the Siberia 584 stages (Ainsaar et al., 2015) also allows a framework onto which the existing 585 magnetostratigraphic data for the Middle to Upper Ordovician can be assembled (Fig. 13).

586 Magnetochrons have been labelled (LO, MO, UO for Lower, Middle and Upper 587 Ordovician) in the polarity chronostratigraphic composite to allow ease of description. This labelling differs from Hounslow (2016); for example magnetochron MO1n is now labelled MO3n, since normal magnetozones now appear to extend to older intervals in the Middle Ordovician. Pavlov and Gallet (2020) have described the Lower Ordovician data in detail.

The earliest Middle Ordovician substantive normal magnetozone (MO1n) occurs on the rising limb of the MDICE isotope excursion (BC3) in both Core-A and the Gullhögen Quarry section (Meidla et al., 2004; Torsvik et al., 1995). Differences in the relationship of MO1n to the Baltic Kunda-Volkov stage boundary reflects the lithostratigraphic nature of this distinction in Core-A, which is instead better defined to be within the Lenodus antivariabilis conodont zone near Gullhögen (Lindskog et al., 2014).

Magnetozone MO1n is likely the equivalent of the major normal polarity magnetozone in the early to mid part of Member B of the Everton Fm (Farr et al., 1993; Fig. 13), which is an unconformity bounded package of carbonates (Etherington et al., 2012). This age relationship is inferred, since the lower part of the Everton Fm contains mid to late Dapingian conodonts (Histiodella altifrons Biozone) as supported by regional correlations (Etherington et al., 2012; Cooper et al., 2012). Normal polarity magnetozones from the underlying Sneeds Mbr (of the Everton Fm), and the older Lower Ordovician, Powell Dolomite, may represent additional normal magnetozones. However, these are not as well validated as those from the overlying parts (Member B) of the Everton Fm, which are based on data from more than one section (Farr et al., 1993). The submagnetochrons MO1n.1n and MO1n.2n are missing in Core-A probably due to the regional disconformity (Meidla et al., 2014) at the Volkhov -

609 Torsvik et al. 1995) contains 12 normal-polarity specimens. This combined with data from

610 Core A and the Everton Mbr indicates this normal magnetochron is well substantiated. A 611 normal magnetozone at this level is not known in the Siberian sections (around the base of 612 the Siberian Vikhorevian Stage, Dronov 2017), an interval there of exclusively reverse 613 polarity (Gallet \& Pavlov, 1996; Pavlov et al., 2012).

614 Magnetozone MO2n, seen in Core A (Fig. 13), is probably equivalent to the latest part of 615 the Kunda Stage seen at Gullhögen, where a single-sample normal-polarity interval (Torsvik 616 et al., 1995) occurs in the top of the Holen Limestone, near the top of the MDICE excursion 617 (Meidla et al., 2004). Magnetozone MO2n was also detected by 3 normal-polarity specimens 618 from nearby Hallekis quarry in the upper Holen Limestone (Torsvik \& Trench, 1991; their 619 'N1' magnetozone). Smethhurst et al. (1998) have also detected a normal polarity 
620 magnetozone in the late Kunda Stage. This is from 4 specimens from two levels in the top $\sim 1$

$621 \mathrm{~m}$ of the Tosna section. Tolmacheva (2005) indicates that the upper part of the Kunda Stage

622 in the St Petersburg area is within the Eoplacognathus pseudoplanus conodont zone of the

623 mid Darriwilian.

624 Tentative normal magnetozones in the Siberian Volginian Stage from the Polovinka (Fig.

625 13) and Rozhkova sections may be equivalent to MO2n, considering the provisional nature of 626 correlation using the Siberian isotope data (Ainsaar et al., 2015). However, Dronov (2017)

627 has correlated the sequence boundary at the base of the Volginian to that at the base of the

628 Baltic Aseri Stage, suggesting that MO2n may be in the Siberian Mukteian Stage underlying

629 the Volginian. In Arkansas, the Jasper Mbr (of the Everton Fm) is early to mid Darriwilian in

630 age (Histiodella sinuosa to H. holodentata conodont zones; Etherington et al., 2012; Cooper

631 et al., 2012) suggesting that magnetochron MO2n is the probable equivalent of the normal

632 polarity magnetozone in the top part of Member $\mathrm{C}$ and into the overlying Jasper Mbr of the

633 Everton Fm (Fig. 13). This suggests the geomagnetic polarity during the Darriwilian may be

634 best represented by the Everton Fm data, since other sections do not show such complexity in

635 reversal pattern through MO1 and MO2n. Greater uncertainties remain about the dating and

636 duration of hiatus in the Siberian Middle Ordovician (Ainsaar et al., 2015; Dronov, 2017), but

637 possibly MO2n has been eroded at the Siberian Mukteian-Volginian sequence boundary. The

638 overlying reverse-polarity dominated MO2r contains at least two brief normal-polarity

639 submagnetozones, represented by those in the Volginian-Kirinian stages in Siberian sections,

640 and in the uppermost part of the Everton Fm (Fig. 13).

641 Magnetozone MO3n is seen in the Baltic Uhaku Stage in Core-A, in the Pakri Cape and 642 Vao Quarry sections and in a single-sample level at Gullhögen, within the BC4 isotope zone

643 (Fig. 13). MO3n is dated to the upper part of the P. serra conodont zone (ca. base of

644 Eoplacognathus lindstroemi Subzone) in the Gullhögen Limestone (Holmer, 1989), and

645 therefore its base likely correlates to the lowest normal magnetozone (MO3n.1n) at Mójcza

646 (Fig. 13). The Siberian Rozhkova section at around the upper parts of BC4 has two normal

647 magnetozones (MO3n.1n and MO3n.2n) compared to the Baltic sections. The Mójcza section

648 similarly has two normal magnetozones in the upper part of the Baltic Uhaku Stage (which

649 overlaps the serra and anserinus biozones; Meidla et al., 2014; of mid to late Darriwilian

650 age). This suggests the polarity data from Baltic sections is incomplete (in Core-A strata

651 missing across the Taurupe- Dreimani boundary?), and so we use the Siberian Kudrino

652 section to construct the composite polarity scale through MO3n and MO3r. Using these

653 relationships suggests magnetozone MO3n ranges into the early part of the $P$. anserinus

654 Biozone (late Darriwilian; Fig. 13).

655 A substantive normal-polarity interval occurs in the Dreimani Fm in Core A, the Dalby

656 Limestone at Gullhögen and the later parts of the Chertovskian in Siberian sections, which

657 we call UO1n. This magnetozone is what Trench et al. (1991) referred to as bias-

658 magnetozone ' $\mathrm{C}(\mathrm{N})$ ', characterised by normal-polarity palaeopole-type data from a number

659 of volcanic-units. At Gullögen, the base of UO1n is not detected due to a large sampling gap,

660 so UO1n may extend into the underlying Ryd limestone (Torsvik et al., 1995; Fig. 13). The

661 Siberian Rozhkova section appears to provide the most detailed record through the interval 
662 MO3r.1n to UO1n, and is used for the composite polarity. At Mójcza, the base of UO1n is

663 within the Prionlodus gerdae Subzone of the tvaerensis Biozone, but the youngest part of the 664 tvaerensis Biozone may be condensed because of phosphatisation at this level (Trela, 2005).

665 In Core-A, UO1n is within the upper part of the Baltic Kukruse Stage, which is within the 666 mid and lower parts of the tvaerensis Biozone (Meidla et al., 2014).

667 Magnetozone UO1r is detected through the Baltic Haljala-Keila-Nabala-Vormsi stages in 668 Core-A, with a probable higher resolution record of the lower part of UO1r (containing 669 UO1r.1n and UO1r.2n) in the Cheney-Longville section (Fig. 13); a correlation supported by 670 chitinozoans (Vandenbroucke, 2008). The Mójcza magnetostratigraphy appears incomplete in 671 the interval covering UO1r (also a sampling gap), likely because of three hiatus in the 672 superbus Biozone (Trela, 2005), suggesting the normal magnetozone beginning at $3 \mathrm{~m}$ is 673 UO2n.1n (Fig. 13). The zonal interpretation of carbon isotope data at Mójcza is tentative, but 674 may range through the BC10-BC11 isotope zones from $~ 3.0-3.5 \mathrm{~m}$ (Fig. 13). The Guttenberg 675 carbon isotope excursion (GICE) is located in magnetochron UO1r.3r probably above the 676 sampled Cheney-Longville section and below the oldest part of the Grabowiec- 6 core.

677 Magnetozone interval UO2n-UO2 $\mathrm{r}$ is found in Core-A, and appears in the lower part of 678 the Grabowiec- 6 core, based on the $\delta^{13} \mathrm{C}_{\text {org }}$ excursions in this core (Figs. 4, 5). This interval is 679 also seen at Mójcza at 3-3.8 m, since the ordovicicus Biozone ranges through the Upper 680 Nabala -Vormsi - Pirgu and Porkuni stages (Meidla et al., 2014). At Mójcza more negative $681 \quad \delta^{13} \mathrm{C}_{\text {carb }}$ values between $3.1-3.5 \mathrm{~m}$ may be $\mathrm{BC} 11$, with overlying $\mathrm{BC} 12$ (more positive 682 isotope values) in the ordovicicus Biozone (Figs. 4, 13). In all sections isotope zone BC12 683 spans the mid part of magnetochron UO2r (containing UO2r.1n).

684 Magnetochron UO3 is seen in isotope zones BC13 - BC14 to lower part of BC15 in Core685 A and Grabowiec-6. The top of the Mójcza Fm is likely within magnetozone UO3r within the 686 BC14 isotope zone, like that in Core-A. Kolesov (2007) has also probably detected the 687 UO3n-UO3r magnetochrons in two Siberian sections on the Lena and Nuya rivers equated to 688 the Pleurograptus linearis Zone. Study of the Dolbor Fm from Siberia (of mid Katian age; 689 Dronov, 2017) by Pavlov and Gallet (2020) has also found only normal polarity, probably 690 equivalent to UO3n. Several other studies of rather poorly dated rocks around this age 691 (Bachtadse et al., 2000; Bazhenov et al., 2003) has lead Pavlov and Gallet (2020) to infer 692 entirely normal polarity for much of the Upper Ordovician, which conflicts with our data, 693 which clearly shows a more complex reversal pattern (Fig. 13).

694 In Core-A, the transition from the Pirgu Stage to the overlying lower part of the Porkuni 695 Stage is interrupted by two hiatus, which may have removed part of the early Hirnantian, a 696 feature commonly inferred in Latvia and Lithuanian (Brenchley et al., 2003; Meidla et al., 697 2014). In Core-A, magnetozone UO4r is likely truncated by the lowest of these hiatus at the 698 base of the Kuldiga Fm, and the top of UO5n is likely truncated by hiatus at the base of the 699 Saldus Fm (Figs. 11, 13). More expanded intervals of the Kuldiga Fm show the progressive 700 increase in $\delta^{13} \mathrm{C}$, younging through to the peak of the HICE excursion in the late Kuldiga Fm 701 or lower parts of the Saldus Fm (Hints et al., 2010). For this reason we have expanded the 702 polarity pattern from the Kuldiga Fm, covering the upper part of UO3r and lower part of 
703 UO4n. This expansion is supported by the reverse-polarity seen in the lower part of isotope

704 zone BC16 in the Grabowiec-6 core (Figs. 12, 13). The sparse Ordovician data through the

705 Ashgill Fm at Backside Beck may represent the interval from upper UO3r into the early part

706 UO5n, with the normal polarity in the Cautley Mudstone Fm being the equivalent of UO4n.

707 This is broadly the correlation suggested by the chitinozoans from the upper part of the

708 Cautley Mudstone Fm, and the Hirnantian fauna in the upper Ashgill Fm and Spengill Mbr.

709 This places the base of the Porkuni Stage in the upper part of the Ashgill Fm at Backside

710 Beck (at $\sim 60 \mathrm{~m}$ level), consistent with the sedimentological evidence of sea-level lowstand

711 in the formation, and the latest Katian low in $\delta^{13} \mathrm{C}$. This would make the base Hirnantian

712 within UO5n, rather than in the top of UO4r. The Katian-Hirnantian boundary needs more

713 work to better place the base Hirnantian with respect to the magnetostratigraphy.

714 The upper part of the Saldus Fm is the only representation of magnetozone UO6, which is 715 in the youngest part of the decline from the $\delta^{13} \mathrm{C}$ peak in the HICE (Figs 4, 11), with the

716 likely minimum in $\delta^{13} \mathrm{C}_{\text {carb }}$ at $1.4 \mathrm{~m}$ below the top of the formation, within UO6r. The top-

717 most sample in the Saldus Fm is of normal polarity, and likely represents the first normal

718 magnetochron, LL1n of the Llandovery (Hounslow et al., inpress).

In the original definition of the Moyero Superchron, Pavlov and Gallet (2005) placed the upper boundary of the superchron equivalent to the top of MO2r, based on data from the Siberian Kudrinian Stage at Kudrino and Moyero (Fig. 13). Retaining this definition, suggests that the Moyero Superchron does not have $100 \%$ bias to a single polarity, like the late Cretaceous Normal-Polarity Superchron (Ogg, 2012), but instead is more like the Carboniferous-Permian, Kiaman Superchron in containing brief normal-polarity intervals (Hounslow and Balabanov, 2016; Hounslow, inpress). In this sense the Paleozoic superchrons seem physically distinct from the Cretaceous Normal-Polarity Superchron. The exclusively reverse-polarity part of the Moyero Superchron appears to be at maximum ca. $10 \mathrm{Myr}$ duration, substantially short than the 39 Myr duration for the Cretaceous Superchron (Olierook et al., 2019). The absence of substantive normal polarity in the Middle Ordovician Siberian sections below MO3n may relate to the issue of potentially missing intervals at the sequence boundaries in these successions (Dronov, 2017). The number of magnetozones through the Darriwilian-Sandbian is larger than that through the Katian-Hirnantian, a probable expression of the larger dataset from the Middle Ordovician, rather than actual larger reversal frequency.

\section{Conclusions}

An Ordovician geomagnetic polarity scale is defined using polarity data from five new successions covering the Middle to Upper Ordovician through the Dapingian to Hirnantian stages. These new datasets are supported by some fold and reversal tests, suggesting the primary nature of the magnetisations, which is carried by variable mixtures of both haematite and magnetite. Using existing biostratigraphy, supplemented by correlations based around new carbon isotope and magnetic susceptibility data, we construct a correlation and age framework onto which these new polarity datasets are tied. 
In combination with existing magnetostratigraphic data from the Dapingian to early Sandbian, we construct the first geomagnetic polarity chronostratigraphic scale through the entire ca. 23.5 Myr of the mid to latest Ordovician. Our new datasets demonstrate a substantial revision in the polarity pattern for the Upper Ordovician. This makes the Ordovician System the first in the early Paleozoic to have a nearly complete record of geomagnetic polarity. The interval which may prove to have a more complex pattern of polarity reversals is around the Katian - Hirnantian boundary.

\section{Acknowledgements}

Some samples for $\delta^{13} \mathrm{C}$ were processed by David Mindham and measured by David Hughes at Lancaster. AMS measurements were performed in the Edinburgh laboratory, with gratitude to Jenny Tait. Some magnetic measurements were performed by Victoria Lucas, Vassil Karloukovski, Alice Gent, David Mindham and Emma Gray. A few samples from Backside Beck were measured at University of Florida by Jim Channell. Marion Grundy, James Griffiths and Luke Morgan helped with fieldwork in the UK and Poland. Wiesiek Trela helped with integrating the datasets for Mójcza. This work was funded by Chevron and partly NERC (grant NE/P00170X/1). Vladimir Pavlov provided constructive comments.

\section{References}

Ainsaar, L., Kaljo, D., Martma, T., Meidla, T., Männik, P., Nõlvak, J., Tinn, O., 2010. Middle and Upper Ordovician carbon isotope chemostratigraphy in Baltoscandia: a correlation standard and clues to environmental history. Palaeogeography, Palaeoclimatology, Palaeoecology 294, 189-201.

Ainsaar, L., Männik, P., Dronov, V., Izokh, O.P., Meidla , T. Tinn, O., 2015. Carbon isotope chemostratigraphy and conodonts of the Middle-Upper Ordovician succession in the Tungus Basin, Siberian Craton. Palaeoworld 24,123-135

Aldridge, R.J., 1986. Conodont palaeobiogeography and thermal maturation in the Caledonides. Journal of the Geological Society 43, 177-184.

Algeo, T.J., 1996. Geomagnetic polarity bias patterns through the Phanerozoic. Journal of Geophysical Research: Solid Earth, 101, 2785-2814.

Bachtadse, V., Pavlov, V.E., Kazansky, A.Y., Tait, J.A., 2000. Siluro-Devonian paleomagnetic results from the Tuva Terrane (southern Siberia, Russia): implications for the paleogeography of Siberia. Journal of Geophysical Research: Solid Earth, 105, 13509-13518.

Bazhenov, M.L., Collins, A.Q., Degtyarev, K.E., Levashova, N.M., Mikolaichuk, A.V., Pavlov, V.E., Van der Voo, R., 2003. Paleozoic northward drift of the North Tien Shan (Central Asia) as revealed by Ordovician and Carboniferous paleomagnetism. Tectonophysics, 366, 113-141.

Belka, Z., 1990. Thermal maturation and burial history from conodont colour alteration data, Holy Cross Mountains, Poland. Courier Forseh.-Inst. Senekenberg 118, 241-251. 
Bergström, S. M., 1980. Conodonts as palaeotemperature tools in Ordovician rocks of the Caledonides and adjacent areas in Scandinavia and the British Isles. Geologiska Foreningens i Stockholm Forhandlingar 102, 377-392.

Bergström, S.M., Saltzman, M.R., Leslie, S.A., Ferretti, A. and Young, S.A., 2015. TransAtlantic application of the Baltic Middle and Upper Ordovician carbon isotope zonation. Estonian Journal of Earth Sciences, 64, 8-12.

Biggin, A.J., Steinberger, B., Aubert, J., Suttie, N., Holme, R., Torsvik, T.H., van der Meer, D.G., van Hinsbergen, D.J.J., 2012. Possible links between long-term geomagnetic variations and whole-mantle convection processes. Nature Geoscience 5, 526-533.

Brenchley, P. J., Newall, G., 1982. Storm-influenced inner-shelf sand lobes in the Caradoc (Ordovician) of Shropshire, England. Journal of Sedimentary Petrology 52, 1257-69.

Brenchley, P.J., Carden, G.A., Hints, L., Kaljo, D., Marshall, J.D., Martma, T. Meidla, T., Nõlvak, J., 2003. High-resolution stable isotope stratigraphy of Upper Ordovician sequences: Constraints on the timing of bioevents and environmental changes associated with mass extinction and glaciation. Geological Society of America Bulletin 115, 89-104.

Briden, J.C., Arthur, G.R., 1981. Precision of measurement of remanent magnetization. Canadian Journal of Earth Sciences, 18, 527-538.

Brodie, C.R., Leng, M.J., Casford, J.S., Kendrick, C.P., Lloyd, J.M., Yongqiang, Z., Bird, M.I., 2011. Evidence for bias in $\mathrm{C}$ and $\mathrm{N}$ concentrations and $\delta^{13} \mathrm{C}$ composition of terrestrial and aquatic organic materials due to pre-analysis acid preparation methods. Chemical Geology 282, 67-83.

Channell, J. E. T., McCabe, C. and Woodcock, N. H., 1993. Palaeomagnetic study of Llandovery (Lower Silurian) red beds in north-west England. Geophys. J. Int. 115; 1085-1094.

Cooper, R. A., Sadler, P. M., Hammer, O., Gradstein, F. M., 2012. The Ordovician Period. In Gradstein, F. M., Ogg, J. G., Schmitz, M. D., Ogg, G.M. (Eds.). The Geologic Time Scale 2012, Elsevier, Oxford, pp. 489-523.

Cramer, B.D., Brett, C.E., Melchin, M.J., Männik, P., Kleffner, M.A., McLaughlin, P.I., Loydell, D.K., Munnecke, A., Jeppsson, L., Corradini, C., Brunton, F.R., 2011. Revised correlation of Silurian Provincial Series of North America with global and regional chronostratigraphic units and $\delta^{13} \mathrm{C}_{\text {carb }}$ chemostratigraphy. Lethaia $44,185-$ 202.

Cromwell, G., Johnson, C.L., Tauxe, L., Constable, C.G., Jarboe, N.A., 2018. PSV10: A global data set for 0-10 Ma time-averaged field and paleosecular variation studies. Geochemistry, Geophysics, Geosystems, 19, 1533-1558.

De Wall, H., Worm, H. U., 2001. Recognition of drilling-induced remanent magnetization by Q-factor analysis: a case study from the KTB-drillholes. Journal of Applied Geophysics, 46, 55-64. 
Dean, W. T., 1958. The faunal succession in the Caradoc Series of south Shropshire. Bulletin of the British Museum of Natural History (Geology) 3, 191-231.

Deenen, M.H., Langereis, C.G., van Hinsbergen, D.J., Biggin, A.J., 2011. Geomagnetic secular variation and the statistics of palaeomagnetic directions. Geophysical Journal International, 186), 509-520.

Dronov, A. V., 2013. Late Ordovician cooling event: Evidence from the Siberian Craton. Palaeogeography, Palaeoclimatology, Palaeoecology 389, 87-95.

Dronov, A., 2017. Ordovician sequence stratigraphy of the Siberian and Russian platforms. In: Montenari, M (ed). Stratigraphy and Timescales:-Advances in Sequence Stratigraphy, Vol. 2, pp. 187-241, Academic Press.

Dronov, A. V., Ainsaar, L., Kaljo, D., Meidla, T., Saadre, T., Einasto, R., 2011. Ordovician of Baltoscandia: facies, sequences and sea-level changes. In: J.C. Gutiérrez-Marco, I. Rábano, García-Bellido, D. (Eds.), Ordovician of the World 14, Cuadernos del Museo Geominero, Madrid, pp 143-150.

Drygant, D., Modliński, Z., Szymański, B. 2006. Lithostratigraphical correlation of the Ordovician in the Biłgoraj-Narol area with deposits of the adjacent regions of the marginal zone of the East European Craton in Poland and Ukraine. Przegląd Geologiczny 54, 219-227.

Dzik, J., 1978. Conodont biostratigraphy and palaeogeographical relations of the Ordovician Mójcza Limestone (Holy Cross Mts., Poland), Acta Palaeontologica Polonica 23, 5172.

Dzik, J., 1994. Conodonts of the Mójcza Limestone. Palaeontologia Polonica 53, 43-128.

Dzik, J., Pisera, A., 1994. Sedimentation and fossils of the Mójcza Limestone, Palaeontologia Polonica 53, 5-41.

Enkin, R.J,. 2003. The direction- correction tilt test: an all purpose tilt/fold test for palaeomagnetic studies. Earth Planet. Sci. Lett. 212, 151-166.

Ethington, R. L., Repetski, J. E., Derby, J.R., 2012. Ordovician of the Sauk megasequence in the Ozark region of northern Arkansas and parts of Missouri and adjacent states, In: Derby, J. R., Fritz, R. D., Longacre, S. A., Morgan, W. A., Sternbach, C. A. (Eds.), The great American carbonate bank: The geology and economic resources of the Cambrian - Ordovician Sauk megasequence of Laurentia: AAPG Memoir 98, 275 300.

Farr, R., Sprowl, D., Johnson, J., 1993, Identification and initial correlation of magnetic reversals in the lower to Middle Ordovician of Northern Arkansas. In: Aissaoui, D.M., McNeill, D.F., Hurley, N.F. (Eds.), Applications of paleomagnetism to sedimentary geology, SEPM Spec. Pub. 49, pp. 83-93.

Floyd, J.D., Williams, M., Rushton, A.W., 1999. Late Ordovician (Ashgill) ostracodes from the Drummuck Group, Craighead Inlier, Girvan district, SW Scotland. Scottish Journal of Geology 35, 15-24. 
Fortey, R. A., Harper, D. A. T., Ingham, J. K., Owen, A. W., Rushton, A. W. A., 1995. A revision of Ordovician series and stages from the historical type area. Geological Magazine, 132, 15-30.

Gallet, Y., Pavlov, V., 1996. Magnetostratigraphy of the Moyero River Section (NorthWestern Siberia): Constraint on the geomagnetic reversal frequency during the early Paleozoic, Geophys. J. Int. 125, 95-105.

Gorjan, P., Kaiho, K., Fike, D. A., Xu, C., 2012. Carbon-and sulfur-isotope geochemistry of the Hirnantian (Late Ordovician) Wangjiawan (Riverside) section, South China: Global correlation and environmental event interpretation. Palaeogeography, Palaeoclimatology, Palaeoecology 337, 14-22.

Grahn, Y., Nõlvak, J., 2007. Ordovician Chitinozoa and biostratigraphy from Skåne and Bornholm, southernmost Scandinavia - an overview and update. Bulletin of Geosciences 82, 11-26.

Grappone, J.M. Chaffee, T. Isozaki Y., Bauert H., Kirschvink, J.L., 2017. Investigating the duration and termination of the Early Paleozoic Moyero Reversed Polarity Superchron: Middle Ordovician paleomagnetism from Estonia. Palaeogeography, Palaeoclimatology, Palaeoecology 485, 673-686

Hailwood, E. A., Ding, F., 1995. Palaeomagnetic reorientation of cores and the magnetic fabric of hydrocarbon reservoir sands. In: Turner, P., Turner, A. (eds) Palaeomagnetic applications in hydrocarbon exploration and production. Geological Society, London, Special Publications, 98, 245-258.

Hannigan, R., Brookfield, M.E., 2013. Inorganic geochemistry of the type Caradoc series (Sandbian to middle Katian, Upper Ordovician), Onny valley, Shropshire, UK. Geol. Mag. 150, 699-727.

Harris, M. T., Sheehan, P. M., Ainsaar, L., Hints, L., Männik, P., Nõlvak, J., Rubel, M., 2004. Upper Ordovician sequences of western Estonia. Palaeogeography, Palaeoclimatology, Palaeoecology 210, 135-148.

Hints, L., Oraspold, A., Nõlvak, J., 2005. The Pirgu Regional Stage (Upper Ordovician) in the East Baltic: lithostratigraphy, biozonation, and correlation. Proceedings of the Estonian Academy of Sciences, Geology 54, 225-259.

Hints, L., Hints, O., Kaljo, D., Kiipli, T., Männik, P., Nõlvak, J., Pärnaste, H., 2010. Hirnantian (latest Ordovician) bio- and chemostratigraphy of the Stirnas-18 core, western Latvia. Estonian Journal of Earth Sciences, 59, 1-24.

Hints, O. Martma, T., Männik, P. Nõlvak, J. Põldvere, A., Shen Y., Viira, V., 2014. New data on Ordovician stable isotope record and conodont biostratigraphy from the Viki reference drill core, Saaremaa Island, western Estonia, GFF 136, 100-104.

Holmer, L. E., 1989. Middle Ordovician phosphatic inarticulate brachiopods from Vastergotland and Dalarna, Sweden. Fossils Strata 26, 1-172. 
897

898

899

900

901

902

903

904

905

906

907

908

909

910

911

912

913

914

915

916

917

918

919

920

921

922

923

924

925

926

927

928

929

930

931

932

933

934

Hounslow, M.W., 2006. PMagTools version 4.2- a tool for analysis of 2-D and 3-D directional data. http://dx.doi.org/10.13140/RG.2.2.19872.58880.

Hounslow M.W., 2016. Geomagnetic reversal rates following Palaeozoic superchrons have a fast restart mechanism. Nature Commun. 7, http://dx.doi.org/10.1038/ncomms12507.

Hounslow, M.W. 2019. GM4Edit (v.5.6) - a windows program to manage, plot, export and manipulate palaeomagnetic magnetometer datasets. http://dx.doi.org/10.13140/RG.2.2.31877.91361/1.

Hounslow, M.W. inpress. A geomagnetic polarity timescale for the Carboniferous. In: Lucas, S. G., Schneider, J.W., Wang,X., Nikolaeva, S. (Eds). The Carboniferous Timescale. Special Publication of the Geol. Society 102. doi.org/10.1144/SP512-2020-102.

Hounslow, M. W., Balabanov, Y., 2016. A geomagnetic polarity timescale for the Permian, calibrated to stage boundaries. In: Lucas, S. G., Shen, S. Z. (Eds.) The Permian Timescale. Geological Society, London, Special Publications, 450, 61-103.

Hounslow, M.W, Domeier, M.J. Biggin, A., 2018. Subduction flux modulates the geomagnetic polarity reversal rate. Tectonophysics, 742, 34-49.

Hounslow, M.W., Harris, S., Wójcik, K. Nawrocki, J., Woodcock, N.H., Ratcliffe, K.T, Montgomery, P. inpress. Geomagnetic polarity during the Early Silurian: the first magnetostratigraphy of the Llandovery. Palaeogeog. Palaeoecol. Palaeoclimat.

Hounslow, M.W., Harris, S., Ratcliffe, K.T., Woodcock, N.H., Wojcik, K., Nawrocki, J., Montgomery, P., submitted. The Telychian oxygenation event (Early Silurian) in Europe: A geochemical and magnetic perspective. Palaeogeography, Palaeoclimatology, Palaeoecology.

Hurst, J.M., 1979. Evolution, succession and replacement in the type Upper Caradoc (Ordovician) benthic faunas of England. Palaeogeography, Palaeoclimatology, Palaeoecology 27, 189-246.

Ingham, J.K.,1966. The Ordovician rocks in the Cautley and Dent districts of Westmorland and Yorkshire. Proceedings of the Yorkshire Geological Society 35, 455-505.

Ingham, J.K., Wright, A.D., 1970. A revised classification of the Ashgill Series. Lethaia 3, 233-242.

Jelenska, M., Bakhmutov, V., Konstantinienko, L., 2005. Palaeomagnetic and rock magnetic data from the Silurian succession of the Dniester basin, Ukraine. Physics of the Earth and Planetary Interiors 149, 307-320.

Kanygin A., Dronov A.V. Timokhin A., Gonta, T., 2010. Depositional sequences and palaeoceanographic change in the Ordovician of the Siberian craton. Palaeogeography, Palaeoclimatology, Palaeoecology 296, 285-296.

Kent, J.T., Briden, J.C., Mardia, K.V., 1983. Linear and planar structure in ordered mulivariate data as applied to progressive demagnetisation of palaeomagnetic remanence. Geophysical Journal Royal Astronomical Society, 81, 75-87. 
935

Khramov, A.N., Rodionov, V.P., 1980. The geomagnetic field during Paleozoic time. J. Geomagn. Geoelectr. 32 (Supplemt III), 99-115.

Kiipli, T., Kallaste, T., Kleesment, A., Nielsen, A., 2009. Corroded hydrothermal quartz in Ordovician altered volcanic ash beds of the Baltoscandian Region. Estonian Journal of Earth Sciences 58, 268-272.

Kiipli, E., Kiipli, T., Kallaste, T., Ainsaar, L., 2010. Distribution of phosphorus in the Middle and Upper Ordovician Baltoscandian carbonate palaeobasin. Estonian Journal of Earth Sciences 59, 247-255.

Kneller, B.C., Scott, R.W., Soper, N.J., Johnson, E.W., Allen, P.M., 1994. Lithostratigraphy of the Windermere Supergroup, Northern England. Geological Journal 29, 219-240.

Kolesov, E.V. 2007. A Palaeozoic magnetostratigraphic scale for North-East Russia and a trans-regional correlation of its reference magnetozones. Bulletin of the North-East Scientific Center, Russian Academy of Sciences, Far East Branch, 4, 31-42 (in Russian).

Lazauskiene, J., Sliaupa, S., Brazauskas, A., Musteikis, P., 2003. Sequence stratigraphy of the Baltic Silurian succession: tectonic control on the foreland infill. In: McCann, T., Saintot, A. (eds) Tracing tectonic deformation using the sedimentary record. Geological Society, London, Special Publications, 208, 95-115.

Lindskog, A. Eriksson, M.E., Pettersson, A.M.L., 2014. The Volkhov-Kunda transition and the base of the Holen Limestone at Kinnekulle, Västergötland, Sweden. GFF 136, 167-171.

Männil, R., Meidla, T., 1994. The Ordovician System of the East European Platform (Estonia, Latvia, Lithuania, Byelorussia, parts of Russia, the Ukraine and Moldova). International Union of Geological Sciences Publication 28, 9-14.

Malec, J., 2006. Silurian in the Holy Cross Mountains. Przewodnik LXXVII Zjazdu Naukowego Polskiego Towarzystwa Geologicznego, Ameliówka k. Kielc, 36-50 (in Polish).

McFadden, P.L., 1998. The fold test as an analytical tool. Geophysical Journal International 135, 329-338.

McFadden, P. L., Reid, A. B., 1982. Analysis of palaeomagnetic inclination data. Geophysical Journal International 69, 307-319.

McFadden, P.L., McElhinny, M.W., 1988. The combined analysis of remagnetisation circles and direct observations in paleomagnetism. Earth Planetary Science Letters 87, 161172.

McFadden, P.L., McElhinny, M.W., 1990. Classification of the reversal test in paleomagnetism. Geophysical Journal International 103, 725-729.

Meidla, T., Ainsaar, L., Backman, J., Dronov, A., Holmer, L., Sturesson, U., 2004. MiddleUpper Ordovician carbon isotopic record from Västergötland (Sweden) and East 
Baltic. In: Hints, O., Ainsaar, L. (Eds.), WOGOGOB-2004 Conference Materials, Tartu University Press, Tartu, pp. 67-68.

Meidla, T., Ainsaar, L., Hints, O., 2014. The Ordovician System in Estonia: In: Bauert, H. Hints, O. Meidla T., Männik, P. (Eds.). The Early to Middle Paleozoic revolution, field guide, 4th annual meeting of IGCP 591, Estonia, Institute of Ecology and Earth Sciences, University of Tartu, Tartu, pp. 10-19.

Modliński , Z. Szymański, B., 2001. The Ordovician stratigraphy and palaeogeography of the Nida-Holy Cross Mts. area, Poland — a review. Geological Quarterly 45, 417-433.

Modliński , Z. Szymański, B., 2008. Ordovician. In: Pacześna, J. (Ed.). Łopiennik IG-1. Profile Głebokich Otworów Wiertniczych Państwowego Instytut Geologicznego 123, 128-131.

Modliński , Z. Szymański, B., 2012. Ordovician. In: Pacześna, J. (Ed.). Białopole IG-1. Profile Głebokich Otworów Wiertniczych Państwowego Instytut Geologicznego 134, 70-71.

Modliński, Z., Jacyna, J., Kanev, S., Khubldikov, A., Laskova, L., Laskovas, J., Pomerancev, R., 1999. Palaeotectonic evolution of the Baltic Syneclise during the Early Palaeozoic as documented by palaeothickness maps. Geological Quarterly 43, 285-296.

Nawrocki, J., 2000. Late Silurian palaeomagnetic pole from the Holy Cross Mountains: constraints for the post-Caledonian tectonic activity of the Trans-European Suture Zone. Earth and Planetary Science Letters 179, 325-334.

Nehring-Lefeld, M. Modliński , Z., Swadowska, E., 1997. Thermal evolution of the Ordovician in the western margin of the East-European Platform: CAI and $\mathrm{R}_{\mathrm{o}}$ data. Geological Quarterly 41, 129-138.

Nõlvak, J., Grahn, Y., 1993. Ordovician chitinozoan zones from Baltoscandia. Review of Palaeobotany and Palynology 79, 245-269.

Nõlvak, J., Hints, O., Männik, P., 2006. Ordovician timescale in Estonia: recent developments. Proceedings of the Estonian Academy of Sciences, Geology, 55, 95108.

Ogg, J. G., 2012. Magnetostratigraphy, In: Gradstein, F. M., Ogg, J. G., Schmitz, M. D., Ogg, G.M. (Eds). The Geologic Time Scale 2012, Oxford, Elsevier, pp. 85-114.

Olierook, H.K., Jourdan, F., Merle, R.E., 2019. Age of the Barremian-Aptian boundary and onset of the Cretaceous Normal Superchron. Earth-Science Reviews, 197, https://doi.org/10.1016/j.earscirev.2019.102906

Oliver, G.J.H., 1988. Arenig to Wenlock regional metamorphism in the paratectonic Caledonides of the British Isles: A review. In: Harris, A. L., Fettes, D. J. (Eds.). The Caledonian-Appalachian Orogen, Geological Society, London, Special Publications 38, pp. 347-363.

Pålsson, C., 2001. Graptolites from the Upper Ordovician Dicranograptus clingani Zone at Järrestad, Scania, southern Sweden. GFF 123, 217-224. 
1012 Paškevičius, J., 2007. Correlation of the Ordovician regional stages of the Baltic palaeobasin with new global stages. Geologija 57, 30-36.

1014 Pavlov, V., Gallet, Y., 1998. Upper Cambrian to Middle Ordovician Magnetostratigraphy from the Kulumbe River Section (Northwestern Siberia), Phys. Earth Planet. Inter. 108, 49-59.

1018

Pavlov, V., Gallet, Y., 2005. Third superchron during the Early Palaeozoic. Episodes 28, 7884.

Pavlov, V.E. and Gallet, Y., 2020. Developing the Cambrian and Ordovician Magnetic Polarity Time Scale: Current Data and Attempt of Synthesis. Izvestiya, Physics of the Solid Earth, 56, 437-460.

Pavlov, V. E., Rodionov, V. P., Khramov, A. N., Gallet, Y. 1999. Magnetostratigraphy of the the early LLandeilian?. Izvestiya. Physics of the Solid Earth, 35, 402-412.

Pavlov, V. E., Bachtadse V., Mikhailov, V., 2008 New Middle Cambrian and Middle Ordovician palaeomagnetic data from Siberia: Llandelian magnetostratigraphy and relative rotation between the Aldan and Anabar-Angara blocks. Earth and Planetary Science Letters 276, 229-242

Pavlov, V. E., Veselovskiy, R. V., Shatsillo, A. V., Gallet, Y., 2012. Magnetostratigraphy of the Ordovician Angara/Rozhkova River Section: Further Evidence for the Moyero Reversed Superchron. Izvestiya, Physics of the Solid Earth 48, 297-305.

Rickards, R.B., 2002. The graptolitic age of the type Ashgill Series (Ordovician), Cumbria,

Rickards, R.B., Woodcock, N.H., 2005. Stratigraphical revision of the Windermere Supergroup (Late Ordovician - Silurian) in the southern Howgill Fells, NW England.

Peters, C., Dekkers, M. J., 2003. Selected room temperature magnetic parameters as a function of mineralogy, concentration and grain size. Physics and Chemistry of the Earth, Parts A/B/C 28, 659-667.

Plado, J., Preeden,U., Pesonen, L. J., Mertanen S., Puura V., 2010. Magnetic history of Early and Middle Ordovician sedimentary sequence, northern Estonia. Geophys. J. Int. 180, $147-157$.

Rickards, R.B., 1988. The base of the Silurian in the Lake District and Howgill Fells, Northern England. Bulletin of the British Museum (Natural History) London, Geology Series 43, 53-57. UK. Proceedings of the Yorkshire Geological Society 54, 1-16.

Rickards, R.B. 2004. The significance of the graptoloid Amphigraptus divergens from the (mid-Rawtheyan) type section of the Ashgill Series, Ordovician. Geological Magazine 141, 735-738. Proceedings of the Yorkshire Geological Society 55, 263-285. 
1049 Rodionov, V. P. 2016. Magnetostratigraphy of the Middle-Upper Cambrian Verkhnyaya Lena Group and Lower Ordovician Ust-Kut formation in the southern Siberian Platform. Stratigraphy and Geological Correlation, 24, 464-485.

Rodionov V.P. ,Gurevich, E.L. 2010. Key magnetostratigraphic sequence from the Lower Ordovician deposits of the NW Siberian Platform. "Neftegazovaa Geologia : Teoria i Praktika" (Petroleum Geology: Theoretical and Applied Studies), All-Russia Petroleum Research Exploration Institute, St Petersburg, 5, (in Russian), http://www.ngtp.ru/eng/rub/2010/38_2010.html

Rushton, A. W. A., Owen, A. W., Owens, R. M., Prigmore, J. K., 2000. British Cambrian to Ordovician Stratigraphy. Geological Conservation Review Series, no. 18. Peterborough, UK: Joint Nature Conservation Committee, 435 pp.

Savage, N. M., Bassett, M. G., 1985. Caradoc-Ashgill conodont faunas from Wales and the Welsh borderland. Palaeontology 28, 679-713.

Schätz, M., Zwing, A., Tait, J., Belka, Z., Soffel, H. C., Bachtadse, V., 2006. Paleomagnetism of Ordovician carbonate rocks from Malopolska Massif, Holy Cross Mountains, SE Poland- magnetostratigraphic and geotectonic implications. Earth and Planetary Science Letters 244, 349-360.

Scott, R.W., Kneller, B.C., 1990. A report on the Ashgill and Llandovery Age rocks of Sheet 38 (Ambleside). Technical Report, British Geological Survey.

Sennikov N.V., Tolmacheva T.Yu., Obut O.T., Izokh N.G., Lykova E.V., 2015. Zonation of the Siberian Ordovician deposits based on pelagic groups of fauna. Russian Geology and Geophysics 56, 594-610.

Smethurst M. A., Khramov, A. N., 1992. A new Devonian palaeomagnetic pole for the Russian platform and Baltica, and related apparent polar wander. Geophys. J. Int. 108, 179-192.

Smethurst, M.A., Khramov, A.N., Pisarevsky, S., 1998. Palaeomagnetism of the Lower Ordovician Orthoceras Limestone, St. Petersburg, and a revised drift history for Baltica in the early Palaeozoic. Geophysical Journal International, 133, 44-56.

Sullivan, N. B., Loydell, D. K., Montgomery, P., Molyneux, S. G., Zalasiewicz, J., Ratcliffe, K. T., Lewis, G., 2018. A record of Late Ordovician to Silurian oceanographic events on the margin of Baltica based on new carbon isotope data, elemental geochemistry, and biostratigraphy from two boreholes in central Poland. Palaeogeography, Palaeoclimatology, Palaeoecology 490, 95-106.

1082

Svensen, H. H., Hammer, Ø., Corfu, F., 2015. Astronomically forced cyclicity in the Upper Ordovician and U-Pb ages of inter-layered tephra, Oslo Region, Norway. Palaeogeography, Palaeoclimatology, Palaeoecology 418, 150-159.

Tarling, D., Hrouda, F., 1993. The magnetic anisotropy of rocks, Chapman and Hall, London, 1086 217 pp. 
1087

1088

1089

1090

1091

1092

1093

1094

1095

1096

1097

1098

1099

1100

1101

1102

1103

1104

1105

1106

1107

1108

1109

1110

1111

1112

1113

1114

1115

1116

1117

1118

1119

1120

1121

1122

1123

1124

1125

Tomczyk, H., 1962. Stratigraphic problems of the Ordovician and Silurian in Poland in the light of recent studies (in Polish with English summary). Prace Instytutu Geologicznego 35.

Tomczykowa, E., 1988. Silurian and Lower Devonian biostratigraphy and palaeoecology in Poland. Biuletyn Instytutu Geologicznego 359, 21-41.

Tomczykowa, E., Tomczyk, H., 1981. Rozwój badań syluru I najniższego dewonu w Górach Swiętokrzyskich. Przewodnik LIII Zjazdu Polskiego Towarzystwa Geologicznego, Kielce, 42-57.

Tolmacheva, T. 2005. Conodonts. In: Dronov, A. Tolmacheva, T., Raevskaya, E.and Nestell M. (eds). Cambrian and Ordovician of St. Petersburg Region, Guidebook of the preconference field trip, Igcp 503 Meeting, St. Petersburg State University, A.P. Karpinsky All-Russian Research Geological Institute, pp 17-19.

Torsvik, T. H., Trench, A., Lohmann, K. C., Dunn, S., 1995. Lower Ordovician reversal asymmetry: An artifact of remagnetization or nondipole field disturbance? Journal of Geophysical Research: Solid Earth, 100(B9), 17885-17898.

Trela, W., 1998. Sedimentary environment of the condensed Ordovician limestones from Mójcza section (Holy Cross Mts.). Geological Quarterly 42, 289-300.

Trela W., 2000. Isotope record $\left(\delta^{18} \mathrm{O}\right.$ and $\left.\delta^{13} \mathrm{C}\right)$ from the Upper Ordovician limestone in Mójcza section (Holy Cross Mts., Central Poland). Przeglad Geologiczny 48, 736740.

Trela, W., 2005. Condensation and phosphatization of the Middle and Upper Ordovician limestones on the Malopolska Block (Poland): Response to paleoceanographic conditions. Sedimentary Geology 178, 219-236.

Trela, W., 2006a. Lithostratigraphy of the Ordovician in the Holy Cross Mountains. Przegląd Geologiczny 54, 622-631.

Trela, W., 2006b. Ordovician in the Holy Cross Mountains: stratigraphic and sedimentary record. Przewodnik LXXVII Zjazdu Naukowego Polskiego Towarzystwa Geologicznego, Ameliówka k. Kielc, 28-35 (in Polish).

Trench, A., Mckerrow, W.S Torsvik, T.H., 1991. Ordovician magnetostratigraphy: a correlation of global data. Journal of the Geological Society 148, 949-957.

Vandenbroucke, T. R. A., 2008. An Upper Ordovician Chitinozoan Biozonation in British Avalonia (England and Wales). Lethaia 41, 275-94.

Vandenbroucke, T. R. A., Rickards, R. B., Verniers, J., 2005. Upper Ordovician chitinozoan biostratigraphy from the Type Ashgill Area (Cautley district) and the Pus Gill section (Dufton district, Cross Fell Inlier), Cumbria, Northern England. Geological Magazine $142,783-807$.

Vandenbroucke, T. R.A., Ancilletta, A., Fortey, R.A., Verniers, J., 2009. A modern assessment of Ordovician chitinozoans from the Shelve and Caradoc areas, Shropshire, and their significance for correlation. Geol. Mag. 146 216-236. 
1126 Vandenbroucke, T. R.A., Recourt, P., Nõlvak, J., Nielsen, A. T., 2013. Chitinozoan biostratigraphy of the Upper Ordovician $D$. clingani and $P$. linearis graptolite biozones on the Island of Bornholm, Denmark. Stratigraphy 10, 281-301.

Walden J., 1999. Remanence measurements. In: Oldfield, F., Walden, J., Smith, J. (Eds.) Environmental Magnetism: a practical guide (No. 6). Quaternary Research Association, London, pp. 63-88.

Watson, G.S., Enkin, R.J., 1993. The fold test in palaeomagnetism as a parameter estimation problem. Geophysical Research Letters 20, 2135-3137.

Winchester, J. A., 2002. Palaeozoic amalgamation of Central Europe: new results from recent geological and geophysical investigations. Tectonophysics 360, 5-21.

\section{Figure Captions}

1138 Fig. 1. Location of sampled sections (block dots) and core (red dots) and other locations 1139 discussed in text (black circle).

1140 Fig. 2. Detailed magnetic and chemostratigraphic data for the Cheney Longville section. a) 1141 NRM intensity and magnetic susceptibility (K). b) Specimen demagnetisation behaviour 1142 showing categorisation into good (S1) and poor (S3) ChRM line-fits; great circle fit quality 1143 range from good (T1) to noisy (T3), and specimens with uninterpretable magnetisation, or 1144 those entirely remagnetised are indicated in the X column (see text for details). c) Interpreted specimen polarity quality, with those specimens in the middle column (X) not assigned a polarity. Best quality specimens indicated as $\mathrm{R}$ or $\mathrm{N}$ and poorest quality in column headed ?? d) Specimen VGP latitude and section magnetic polarity. Filled symbols = those specimens possessing an S-class ChRM, and unfilled symbols for specimens with T-class, great-circle behaviour. Polarity bar widths in the section polarity column correspond to interpreted quality of the polarity interpretation, with full-bar width corresponding to good quality and 1/4 bar width to lowest confidence. e) Carbon isotope and total organic carbon (\%TOC) data.

Fig. 3. Detailed magneto and chemo-stratigraphic data for the Mójcza section. See Fig. 2 for

1154 Fig. 4. Lithostratigraphy, surface magnetic susceptibility $\left(\mathrm{K}_{\text {surf }}\right)$ and carbon isotope data for 1155 Core-A. The carbon isotope stratigraphy and lithostratigraphy for well Jurmala R-1 (Latvia, 1156 Fig. 1) from Ainsaar et al. (2010), allows interpretation of the fragmented isotope stratigraphy 1157 from Core A. The BC isotope zones and positive isotope peak names from Jurmala R-1 are 1158 those of Ainsaar et al. (2010). Isotope zones on Core-A are interpreted. MDICE, GICE, HICE are the mid Darriwilan, Guttenburg and Hirnantian isotope excursions respectively.

1160 Fig. 5. Correlation between the Ordovician in Grabowiec-6 and Zwierzyniec-1 wells, based 1161 primarily on the surface magnetic susceptibility $\left(\mathrm{K}_{\text {surf }}\right)$ data between the two cores, but 1162 assisted by the biostratigraphy. Geochemical and biostratigraphic data from Sullivan et al. 1163 (2018). Isotope zone labels and names as in Fig. 4. Coloured bands and dotted lines represent correlated levels and intervals. 
1165 Fig. 6. Detailed magnetostratigraphic data for the Backside Beck section. See Fig. 2 for

1166 column details. A more detailed log of sampling spots and lithological key is in SI Fig. S3.

1167 Fig. 7. Isothermal remanent magnetisation (IRM) acquisition curves for representative 1168 specimens from the sections and cores. Specimen names (e.g. CL33 from Cheney Longville 1169 section in a)) and sample depths marked on Figs. 2, 3, 6, 11 and12.

1170 Fig. 8. Example demagnetisation data for specimens. In each case a) to j) consists of a

1171 Zjiderveld diagram, stereonet and intensity decay $\left(\mathrm{J} / \mathrm{J}_{\mathrm{o}}\right)$ plot (sometimes aligned vertically).

1172 All in stratigraphic coordinates, except a) which is in geographic coordinates. Points plotted

1173 in black are thermal demagnetisation and in blue are AF demagnetisation steps. Key to

1174 Zijderveld and stereonets in b). Where can be clearly shown, the Zijderveld plot has the

1175 ranges over which components extracted are shown with coloured arrows, and on the

1176 stereonet the direction of the associated components (key under a)). Measurement confidence

1177 cones around some steps shown when $\gamma_{95}$ (Briden and Arthur, 1981) is $>20^{\circ}$. A) Backside

1178 Beck, BB54.2 (66.8 m, demagnetisation type=T1, polarity rating=N) shows a Kiaman 1179 components from $100^{\circ} \mathrm{C}-340(40 \mathrm{mT})$ and normal-polarity ChRM from $340(40 \mathrm{mT})$ to

1180 origin. The Kiaman component in geographic coordinates is shown and the ChRM in 1181 stratigraphic coordinates are shown on the stereonet. B) Cheney Longville (CL1.2, S3, N). A 1182 three component magnetisation with a dominant Brunhes-component NRM- $250^{\circ} \mathrm{C}$, Kiaman1183 like component 415-440 (15 to $40 \mathrm{mT}$ ) and a normal-polarity ChRM from 450 (50 mT) to the 1184 origin. C) Cheney Longville (CL20.1, S3, R), height $=10.23 \mathrm{~m}$. A two component 1185 magnetisation with a dominant Brunhes component NRM-200 ${ }^{\circ} \mathrm{C}$, and a reverse-polarity 1186 ChRM from $430(30 \mathrm{mT})$ to the origin. D) Mójcza (MOZ-4y), height $=0.75 \mathrm{~m}$. Three 1187 component magnetisation, with a Brunhes-component NRM-250 ${ }^{\circ} \mathrm{C}$, Devonian-like 1188 component $250-400^{\circ} \mathrm{C}$, and a much weaker reverse-polarity ChRM, extracted during $\mathrm{AF}$ 1189 steps 405-425 (5 to $25 \mathrm{mT}$ ). The remaining undemagnetised direction is Brunhes-like. E) 1190 Mójcza (MOZ-1y, T1, N), height $=0.15 \mathrm{~m}$. Three component magnetisation, with a Brunhes 1191 component $150-225^{\circ} \mathrm{C}$, a Kiaman component $225-350^{\circ} \mathrm{C}$, with the last steps showing a partial 1192 great circle trend to normal-polarity ChRM (demagnetisation class T1). F) Grabowiece-6 1193 (3809.67 m, S3, R?). Three component magnetisation with a strong Brunhes component 100$1194210^{\circ} \mathrm{C}$, Kiaman component $400-430^{\circ} \mathrm{C}$, and a reverse-polarity ChRM from $430^{\circ} \mathrm{C}$ to origin.

1195 G) Grabowiece-6 (3806.77 m, S3, N). Three component magnetisation with a strong Brunhes 1196 component, NRM-300 ${ }^{\circ} \mathrm{C}$; Kiaman component 300-530 (30 mT) and a normal-polarity ChRM 1197 from $560(60 \mathrm{mT})$ to the origin. H) Core-A $(69.15 \mathrm{~m}, \mathrm{~S} 3, \mathrm{~N})$. A two component 1198 magnetisation with a 'Brunhes-like' component, NRM- $150^{\circ} \mathrm{C}$ (not used to orient core) and a 1199 normal-polarity $\mathrm{ChRM}$ component from $440^{\circ} \mathrm{C}$ to the origin. Intermediate steps show strong 1200 component overlap. Thermal steps above $460^{\circ} \mathrm{C}$ have been removed due to large thermal 1201 alteration. I) Core-A (4.13 m, S2, R). A two component magnetisation with a dominant 1202 Brunhes component, NRM-200 ${ }^{\circ} \mathrm{C}$, and reverse-polarity ChRM from $415(15 \mathrm{mT})$ to the 1203 origin. J) Core-A (62.38 m, S1, N). A two component magnetisation with a Brunhes 1204 component, NRM- $150^{\circ} \mathrm{C}$ and a normal-polarity ChRM from $250-525^{\circ} \mathrm{C}$.

1205 Fig. 9. Characteristic remanence (ChRM) directions for the Cheney Longville (top panel) 1206 and Mójcza (bottom panel) sections. Insitu directions shown on the left, bedding corrected in 
1207 the middle and bedding corrected poles to remagnetisation circles on the right. The planes

1208 through the ChRM great circle poles have a pole which is near the mean of the ChRM line-fit

1209 directions in each site (or age interval for Mójcza). The great circle line-fit ChRM plane

1210 (derived from the S-class data) is shown on the right most stereonets. S1 to S3 indicate the

1211 demagnetisation behaviour explained in the text. Symbol keys for stereonets in box.

1212 Fig. 10. Topmost panel data for Grabowiec-6 and bottom panel for Core-A. a) Kiaman

1213 component in Grabowiec-6 re-oriented using the LT component (i.e. rotated to $0^{\circ}$

1214 declination). b), e) Low stability (LT) components for Grabowiec-6 and Core-A, with in b),

1215 the re-oriented LT component using the Kiaman component (for Grabowiec-6). c), f) ChRM

1216 directions re-oriented using the Kiaman and LT component respectively. d) Poles to great

1217 circles for the T-class ChRM from Grabowiec-6 (see Fig. 9 caption). g) Mean ChRM

1218 inclination, $95 \%$ confidence cone $\left(\alpha_{95}\right)$, Fisher $\mathrm{k}$, and n number of specimens of Baltican

1219 stage intervals for Core-A.

1220 Fig. 11. Detailed magnetostratigraphic data for Core-A. See Fig. 2 for column details. The

1221 intervals used for the mean inclinations are those in Fig. 10g. Information about core-

1222 reorientation of directions in Fig. 10f. Width of bar for mean inclination is $2 * \alpha_{95}$.

1223 Fig. 12. Detailed magnetostratigraphic data for the Grabowiec-6 core. See Fig. 2 for column

1224 details. Biostratigraphic data from Sullivan et al. (2018). Stages, $\delta^{13} \mathrm{C}$ zones of Ainsaar et al.

1225 (2010) and chitinozoans from Fig. 5.

1226 Fig. 13. Summary polarity chronoscale for the Dapingian to Hirnantian (rightmost) and the

1227 source polarity data. Each section or core has its own meter scale. Magnetic polarity data

1228 from: lower part of Mójcza section from Schätz et al. (2006); Gullhögen from Torsvik et al.

1229 (1995); Pakri Cape and Vao Quarry from Grappone et al. (2017); Popovka, Tosna, Lava from

1230 Smethhurst et al. (1998); Polovinka from Pavlov et al. (1999); Moyera from Gallet \& Pavlov

1231 (1996); Kudrino from Pavlov et al. (2008); Rozhkova from Pavlov et al. (2012). Buffalo and

1232 White River from Farr et al. (1993). The exclusively reverse polarity of the Polovinka and

1233 Moyero sections below the Siberian Volginian Stage is not shown. See section 5 for details. 


\begin{tabular}{|c|c|c|c|c|c|c|c|c|}
\hline Section/core [code] & Age/mean type & $\begin{array}{l}\text { Mean } \\
\text { Dec/Inc }\left({ }^{\circ}\right)\end{array}$ & $\mathrm{k} / \alpha 95\left(^{0}\right)$ & $\mathbf{N s} / \mathbf{N}_{T} / \mathbf{N}_{\mathrm{I}} / \mathbf{N}_{\mathbf{p}}$ & $\begin{array}{l}\text { Reversal Test } \\
{\left[\gamma_{0} / \gamma_{c}\right]\left({ }^{\circ}\right)}\end{array}$ & $\begin{array}{l}\text { VGP Pole } \\
\text { Long./Lat. } \\
\left({ }^{\circ}\right)\end{array}$ & $D_{p} / D_{m}\left(^{0}\right)$ & $\begin{array}{l}\mathrm{A95}(\min , \max ), \\
\% \mathrm{VGP}_{45}\end{array}$ \\
\hline Backside Beck [BB] & Ordovician/ GC mean & $31.7 /-17.1$ & $12.1 / 6.9$ & $7 / 21 / 3 / 9$ & $\begin{array}{l}\text { Ro [22.1, } \\
20.3]\end{array}$ & $323.6 /-21.5$ & $3.7 / 7.1$ & $8.1(5.5,24.1), 0$ \\
\hline Cheney & Fisher mean & $338.7 /-57.7$ & $17.4 / 6.2$ & $13 / 68 / 33 / 0$ & $\operatorname{Rc}[9.5 / 17.8]$ & $13.7 / 2.7$ & $6.7 / 9.1$ & $11.9(4.2,15.6)$ \\
\hline Longville [CL] & GC mean & $341.5 /-58.2$ & $12.2 / 4.3$ & $34 / 68 / 33 / 19$ & $\operatorname{Rc}[7.0 / 14.2]$ & $11.5 / 2.8$ & $4.7 / 6.4$ & $7.1(2.9,8.9), 1.5$ \\
\hline Möjcza [M] & Silurian/ GC mean & $35.3 /-19.9$ & $8.8 / 15.2$ & $8 / 28 / 4 / 9$ & n.p & $343 /-21.7$ & $8.3 / 15.9$ & $13.2(5.2,22)$ \\
\hline " & Ordovician/ GC mean & $3.8 /-53.3$ & $10.7 / 5.6$ & $10 / 26 / 10 / 9$ & $\mathrm{R}-[24.7 / 14.1]$ & $17.5 /-5.2$ & $5.4 / 7.8$ & $10.5(4.8,19.2), 9$ \\
\hline Grabowiec-6 & Fisher mean & $27 /-41.2$ & $6.6 / 21.7$ & $6 / 46 / 9 / 0$ & n.p & - & - & $30(5.6,26.5)$ \\
\hline " & GC mean & $29.6 /-37.0$ & $5.8 / 9.0$ & $20 / 46 / 9 / 11$ & $\mathrm{R}-[25.2 / 22.6]$ & $355.0 /-13.8$ & $6.2 / 10.6$ & $12.0(3.6,12.4), 10$ \\
\hline Core-A & Pirgu-Porkuni/Fisher Mean & $14.6 /-33.6$ & $7.3 / 9.4$ & $37 / 59 / 37 / 0$ & $\mathrm{R}-[22.4 / 17.7]$ & $7.8 /-16.5$ & $6.1 / 10.7$ & $9.9(2.8,8.4), 17$ \\
\hline " & Uhaku-Vormsi/ Fisher Mean & $359.5 /-59.5$ & $8.7 / 9.6$ & $29 / 36 / 29 / 0$ & $\mathrm{R}_{\mathrm{I}}[13.9 / 20.7]$ & $22.6 /-4.2$ & $8.5 / 12.8$ & $11.6(3.1,9.8)$ \\
\hline “" & Billingen-Kunda/Fisher Mean & $344.0 /-51.6$ & $6.6 / 13.4$ & $21 / 29 / 21 / 0$ & $\operatorname{Ro}[40 / 42.5]$ & $35.7 /-1.2$ & $12.4 / 18.3$ & $13.7(3.6,12.1)$ \\
\hline
\end{tabular}

Table 1. Mean palaeomagnetic directions for the sections and cores. Code=sample code. $\mathrm{k} / \alpha_{95}=$ Fisher concentration parameter and $95 \%$ cone of confidence. $\mathrm{N}_{\mathrm{s}}=$ number of levels (sites) used, $\mathrm{N}_{\mathrm{T}}=$ Total specimens measured, $\mathrm{N}_{\mathrm{l}}=$ Number of specimens with line-fits, $\mathrm{N}_{\mathrm{p}}=$ Number of specimens with great circle (GC) fits. GC means determined with method of McFadden and McElhinney (1988) for $\mathrm{N}_{1}+\mathrm{N}_{\mathrm{p}}$ data and Fisher mean for $\mathrm{N}_{1}$ data. For the reversal test (McFadden and McElhinny, 1990), $\gamma_{0}=$ observed angle; $\gamma_{c}=$ critical angle. Virtual geomagnetic pole (VGP) is the normal pole. $\mathrm{N} . \mathrm{p}=$ not possible. A95 (min, max) = Fisher 95\% confidence interval for VGP-based site mean $\left(\mathrm{N}_{\mathrm{s}}\right.$ sites), and A95 $\min$ and A95 $\max$ threshold values of Deenen et al. (2011). $\% \mathrm{VGP}_{45}=$ percent of samples yielding VGP latitude < 145I, as a reflection of the match to modern geomagnetic field models and palaeomagnetic data in which $\% \mathrm{VGP}_{45}$ is a $3-4 \%$ (Cromwell et al., 2018). \% VGP 45 applies to all the section or core. Statistics determined with Pmagtool v.5 (Hounslow, 2006). 


\begin{tabular}{|l|l|l|l|}
\hline Section & $\begin{array}{l}\text { Proportional } \\
\text { \%uf [lower, upper }]\end{array}$ & $\begin{array}{l}\text { Direction- correction } \\
\mathbf{\% u f ~ [ c o n f i d e n c e ~ i n t e r v a l ] ~}\end{array}$ & $\begin{array}{l}\text { McFadden } \\
\mathbf{\%} \mathbf{0}\left[\mathbf{f}_{\mathbf{d}}, \boldsymbol{\%} \mathbf{P}_{\mathbf{f}}\right], \mathbf{1 0 0 \%}\left[\mathbf{f}_{\mathbf{d}}, \boldsymbol{\%} \mathbf{P}_{\mathbf{f}}\right], \mathbf{N g}\end{array}$ \\
\hline Backside Beck (N=37) & $100[66,147]$ & $132[ \pm 34]$ & $0[5.7,0.5], 100[1.5,23], 2$ \\
\hline
\end{tabular}

Table 2. Fold test data for the Backside Beck section ( $\mathrm{N}=$ number of data used). The three right hand columns indicate results from three types of fold tests, the proportional (Tauxe \& Watson, 1994), the direction correction (DC) fold test (Enkin, 2003) and the 'means' fold test of McFadden (1998). The proportional and DC fold tests display the $95 \%$ confidence interval on the degree of unfolding. \%uf= best degree of unfolding, values in [..] indicate the unfolding $\%$ of the confidence interval. Bootstrap confidence intervals use 2000 simulations. N= number of groups defined in McFadden fold test. Uses combined Silurian and Ordovician data (Silurian data from Hounslow et al. submitted-a). In the McFadden fold test the value of $\mathrm{P}_{\mathrm{f}}$ indicates the probability the magnetisation was acquired at that percent folding, so that when $\mathrm{P}_{\mathrm{f}}$ exceeds $5 \%$ it suggests it could have been acquired at that state (only $0 \%$ and $100 \%$ shown). $\mathrm{Ng}$ =number of bedding attitude groups in McFadden fold test. $\mathrm{F}_{\mathrm{d}}$ is the f-statistic in the McFadden fold test. Tests determined with the Pmagtool software (Hounslow, 2006), and further details on these tests are in SI Figs. S10 to S13 and Table S3. 

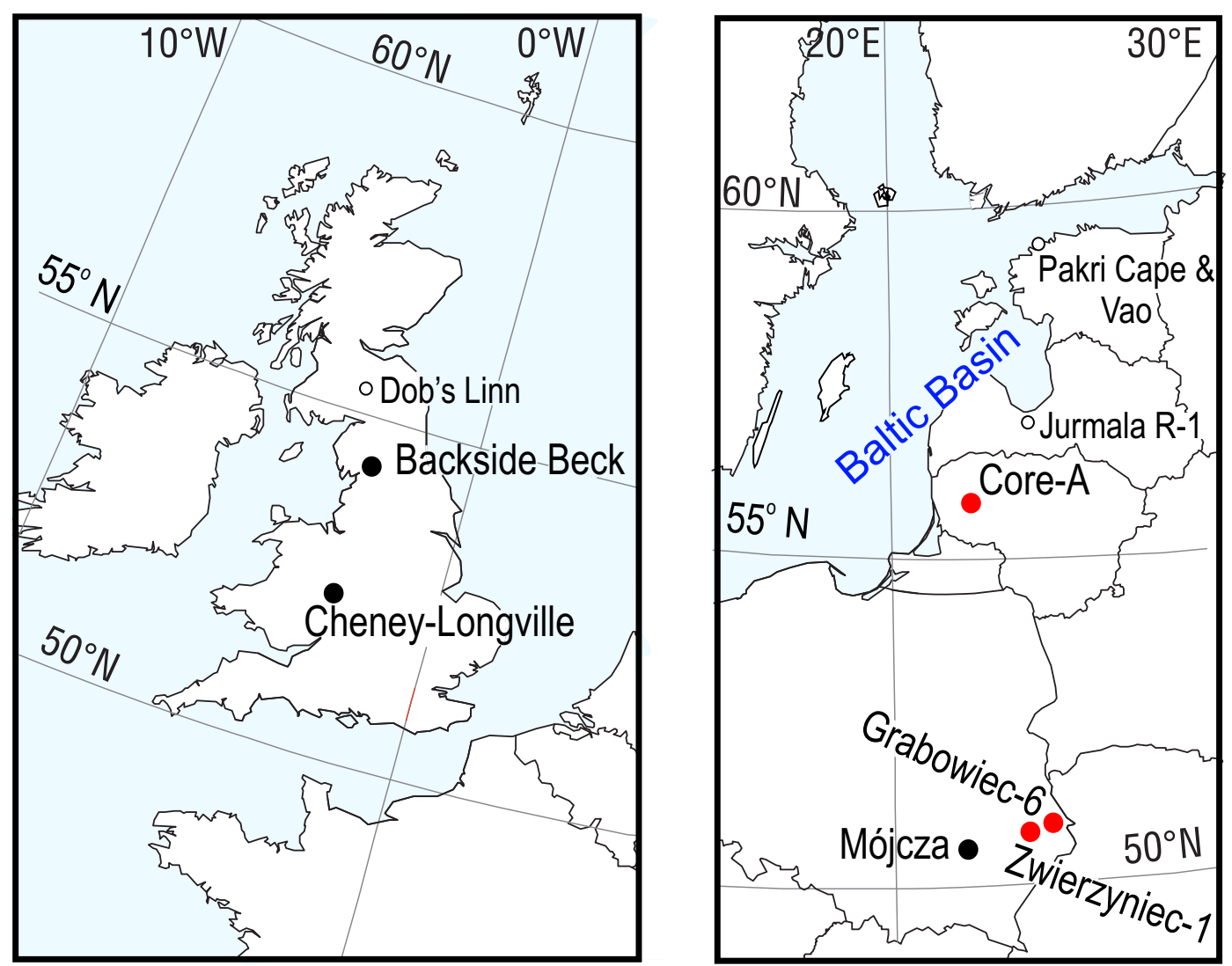

Fig. 1. 


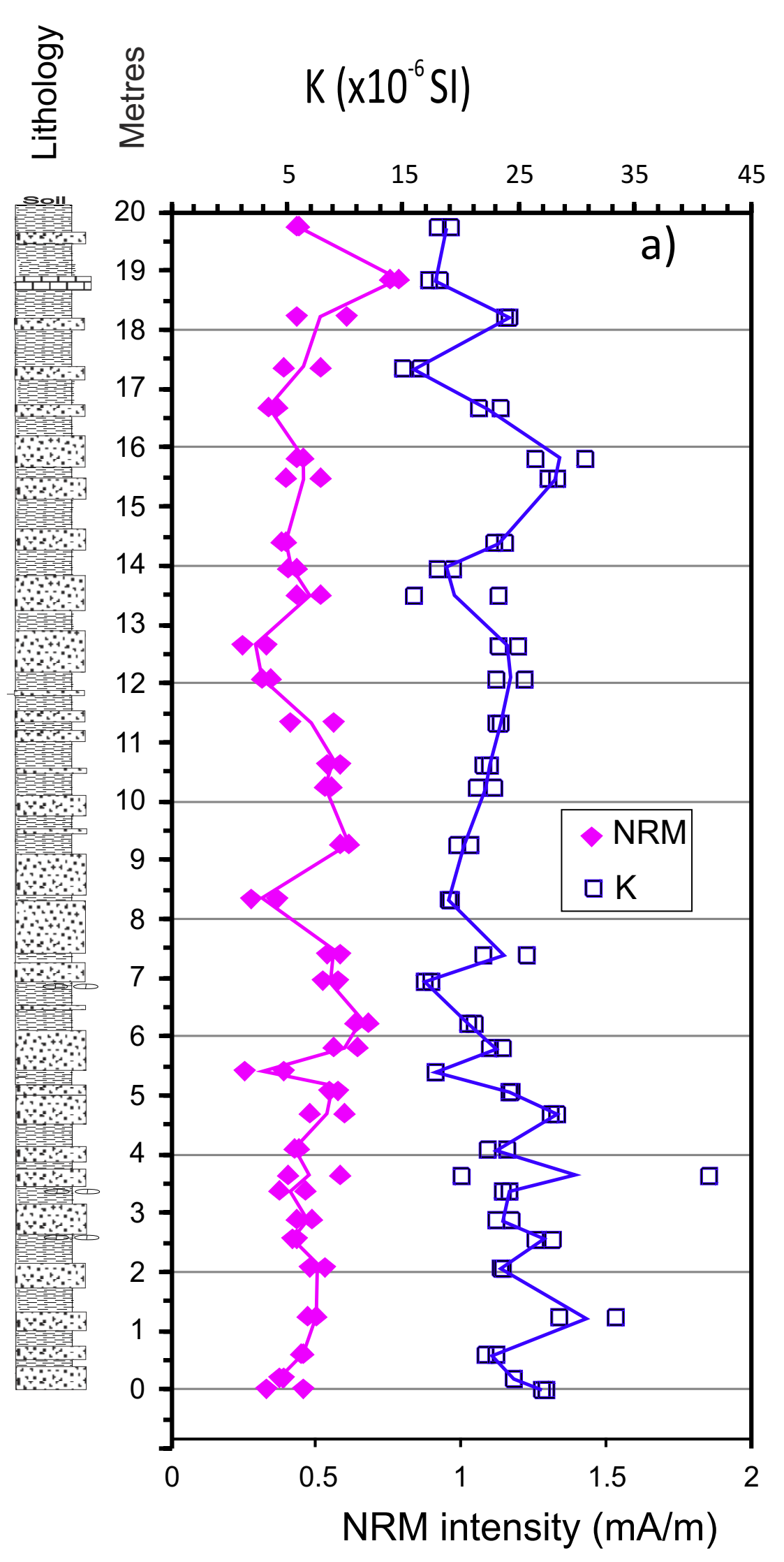

Demagnetisation

behaviour

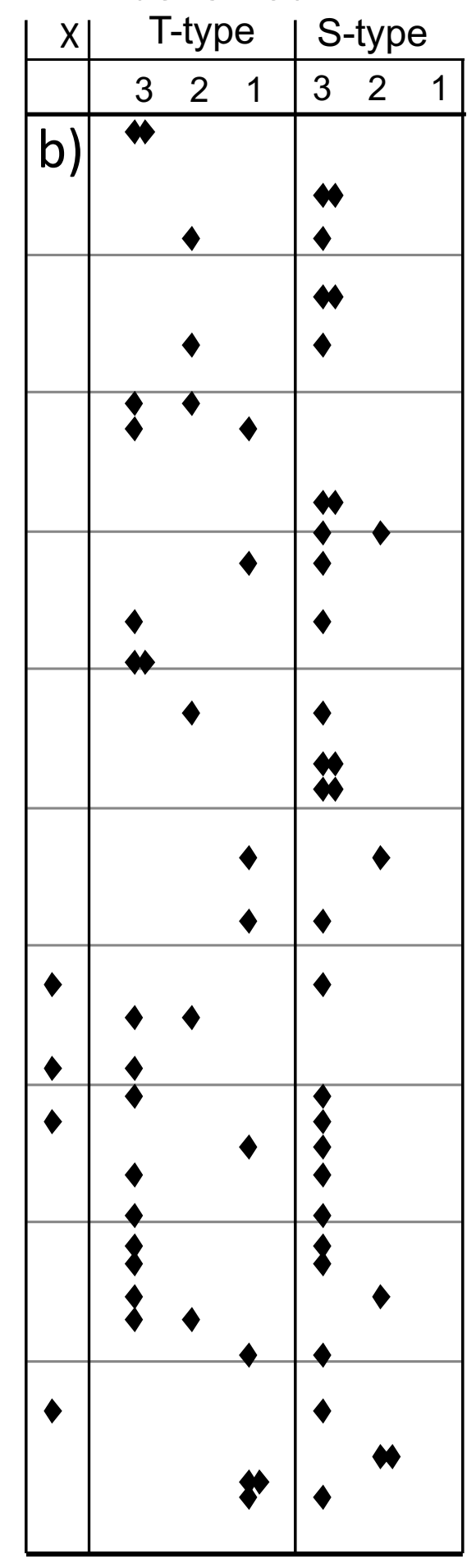

Limestone 1.] Sandstone
Specimen

Polarity Quality

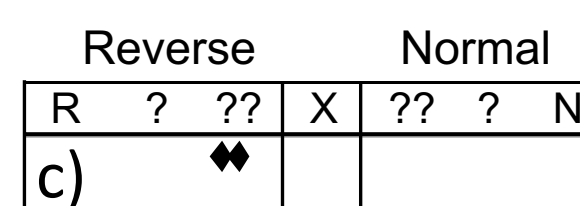

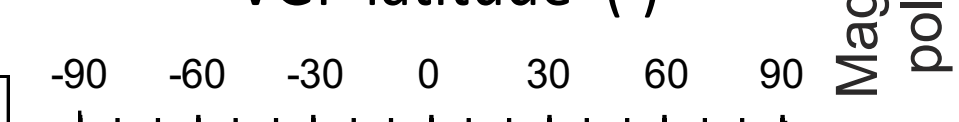
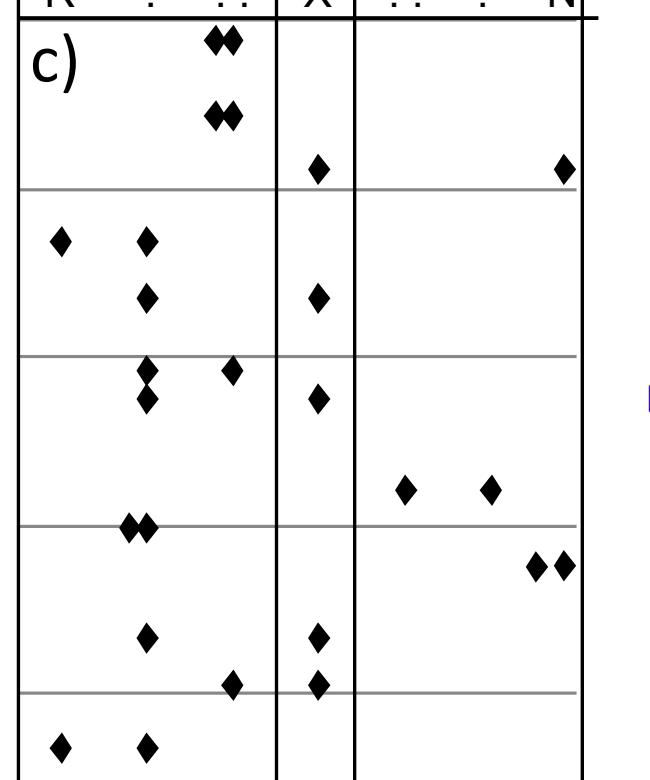

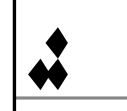

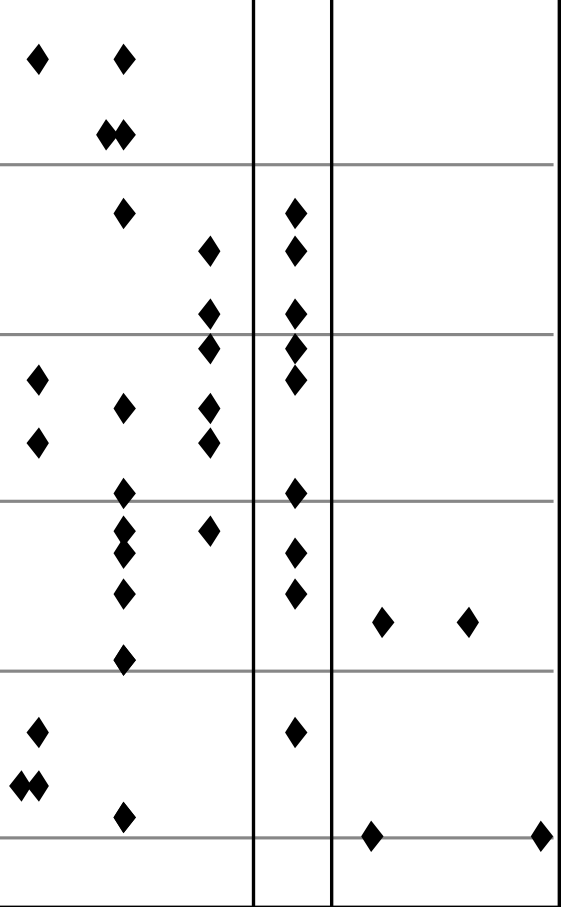

Pale brown silty mudstone Concretion

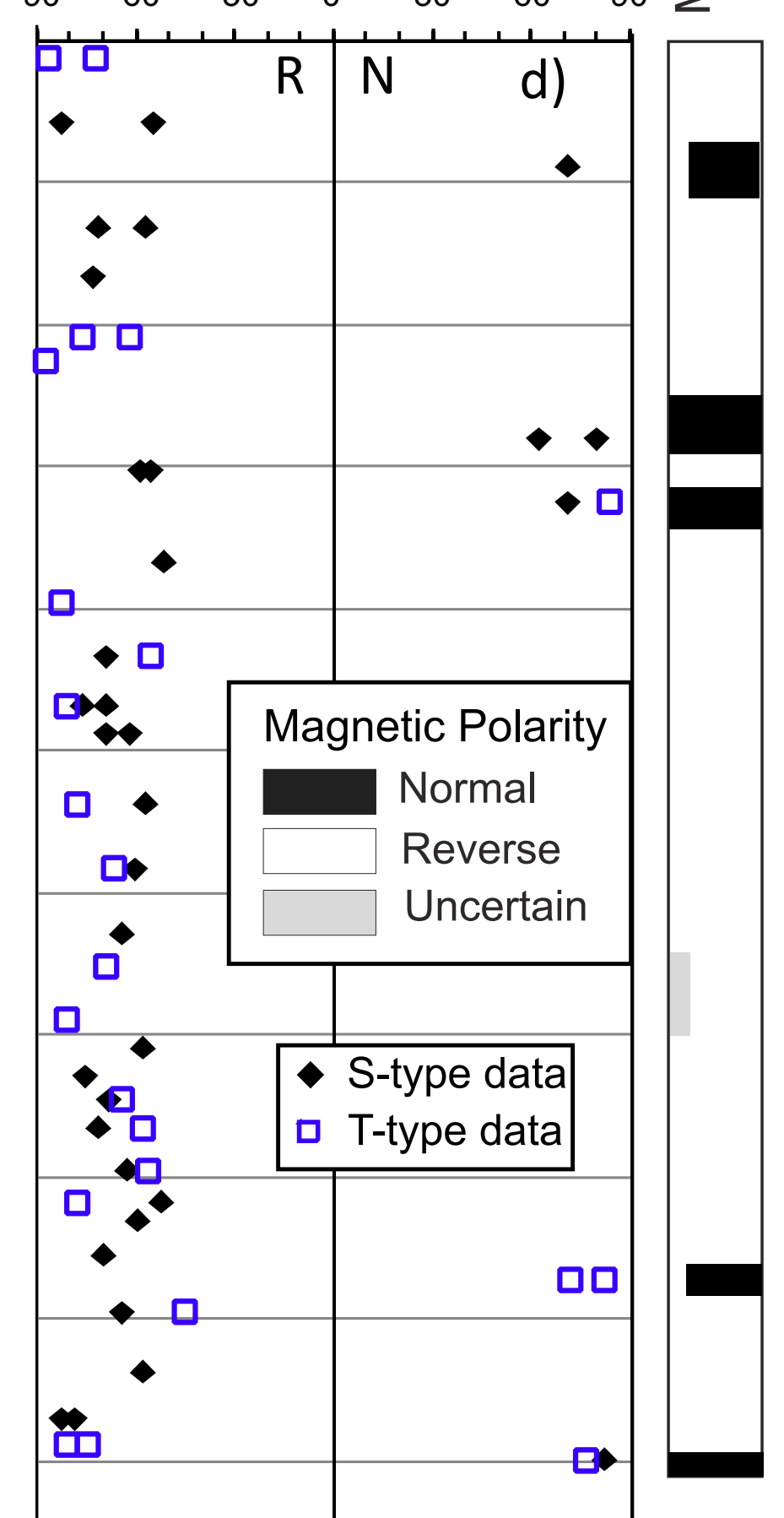

$\begin{array}{lllll}-30 & -29 & -28 & -27 & -26\end{array}$

e)

TOC (\%)

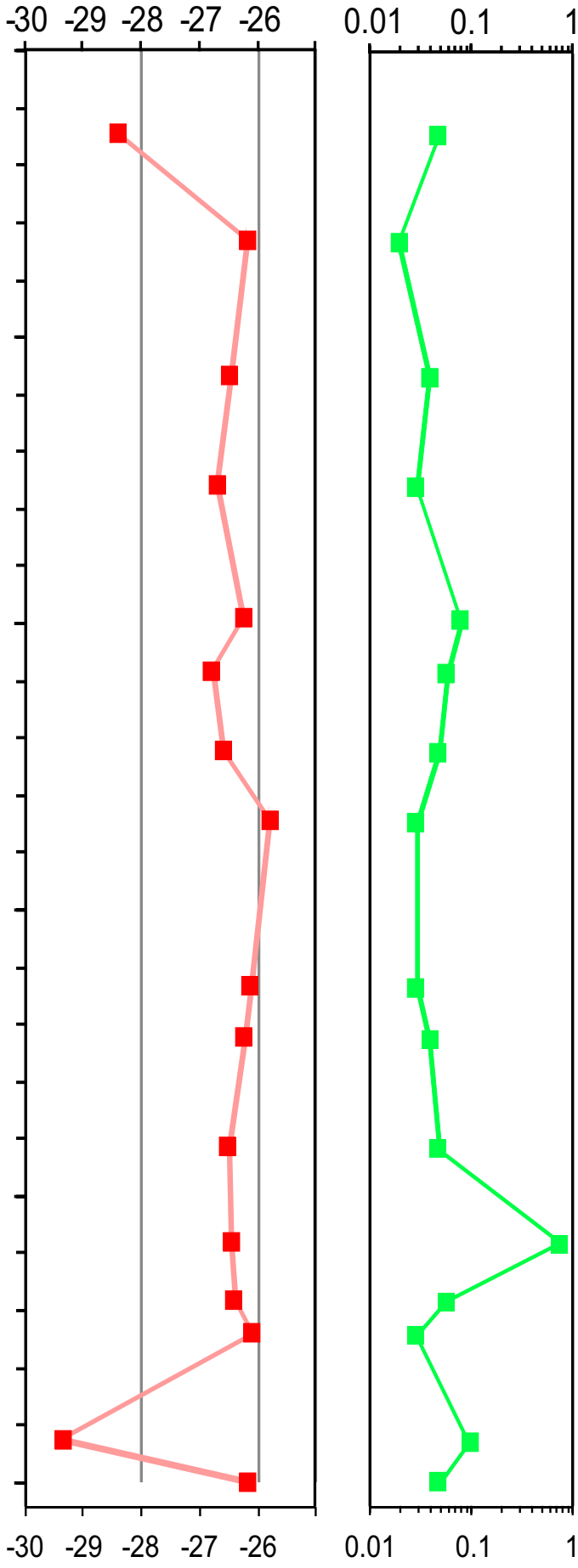

Fig. 2. 


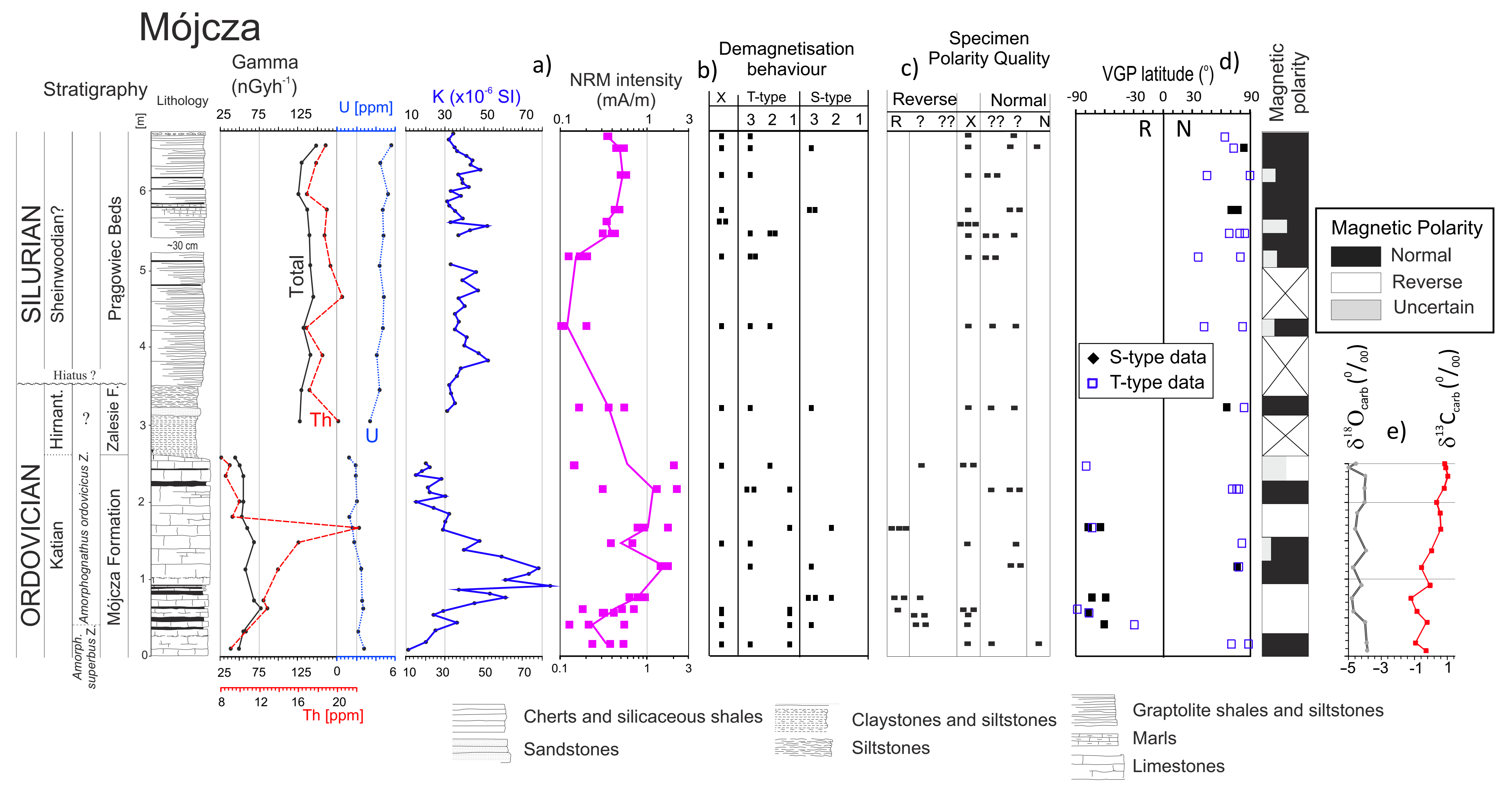

Fig. 3. 


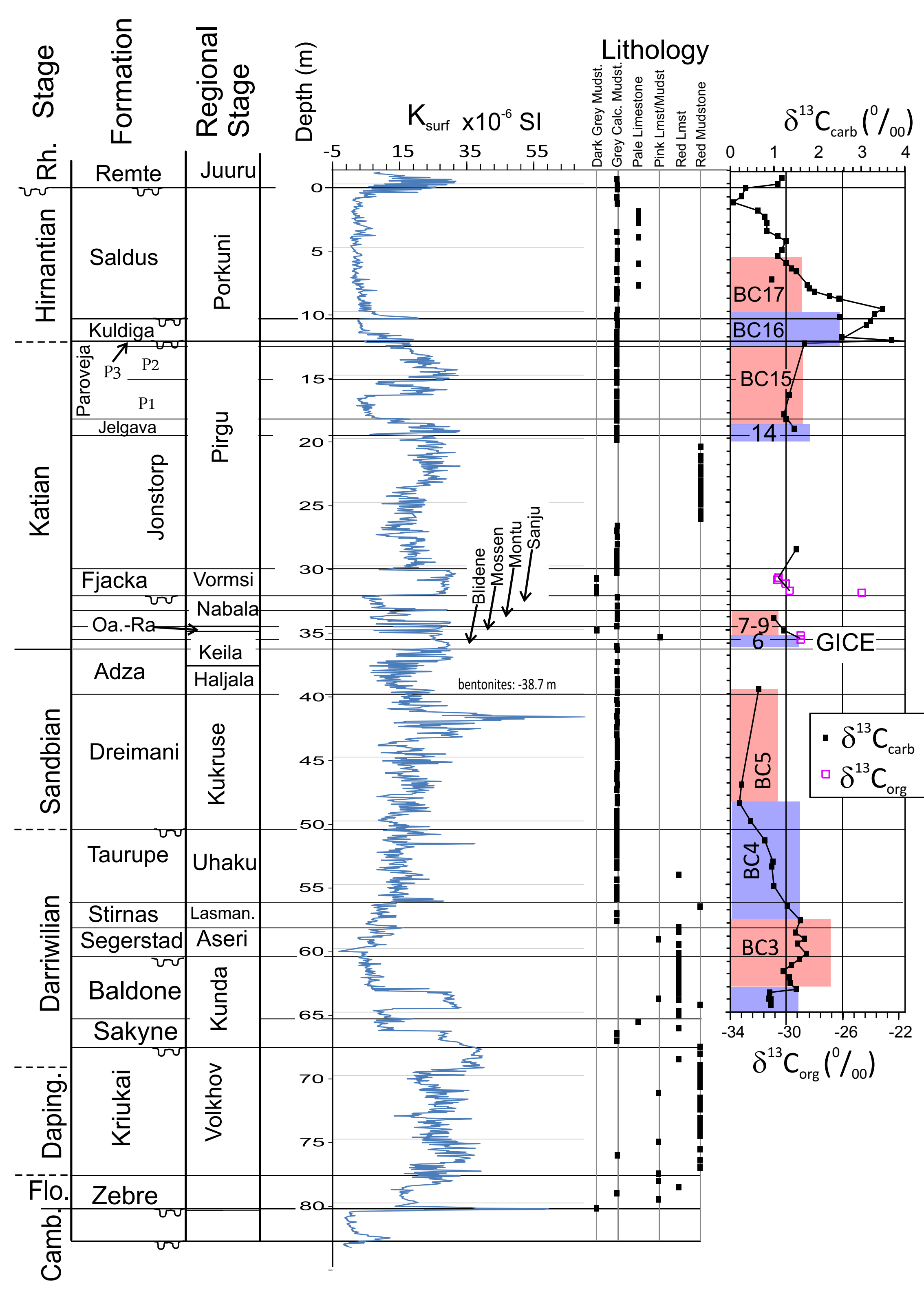

\section{JURMALA R-1}

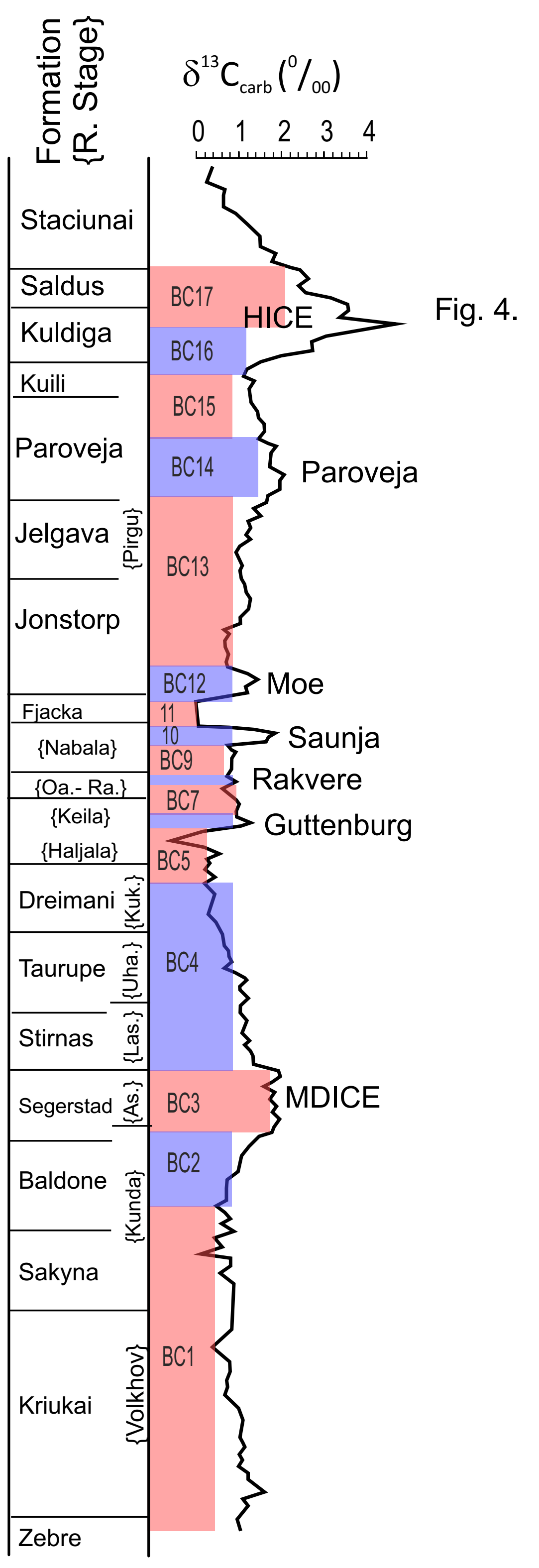


a) $\mathrm{K}_{\text {surf }} \times 10^{-6} \mathrm{SI}$

Z w i e r z y $\underset{\mathrm{Fe} / \mathrm{i} i}{\mathrm{e}} \mathrm{c}-1$

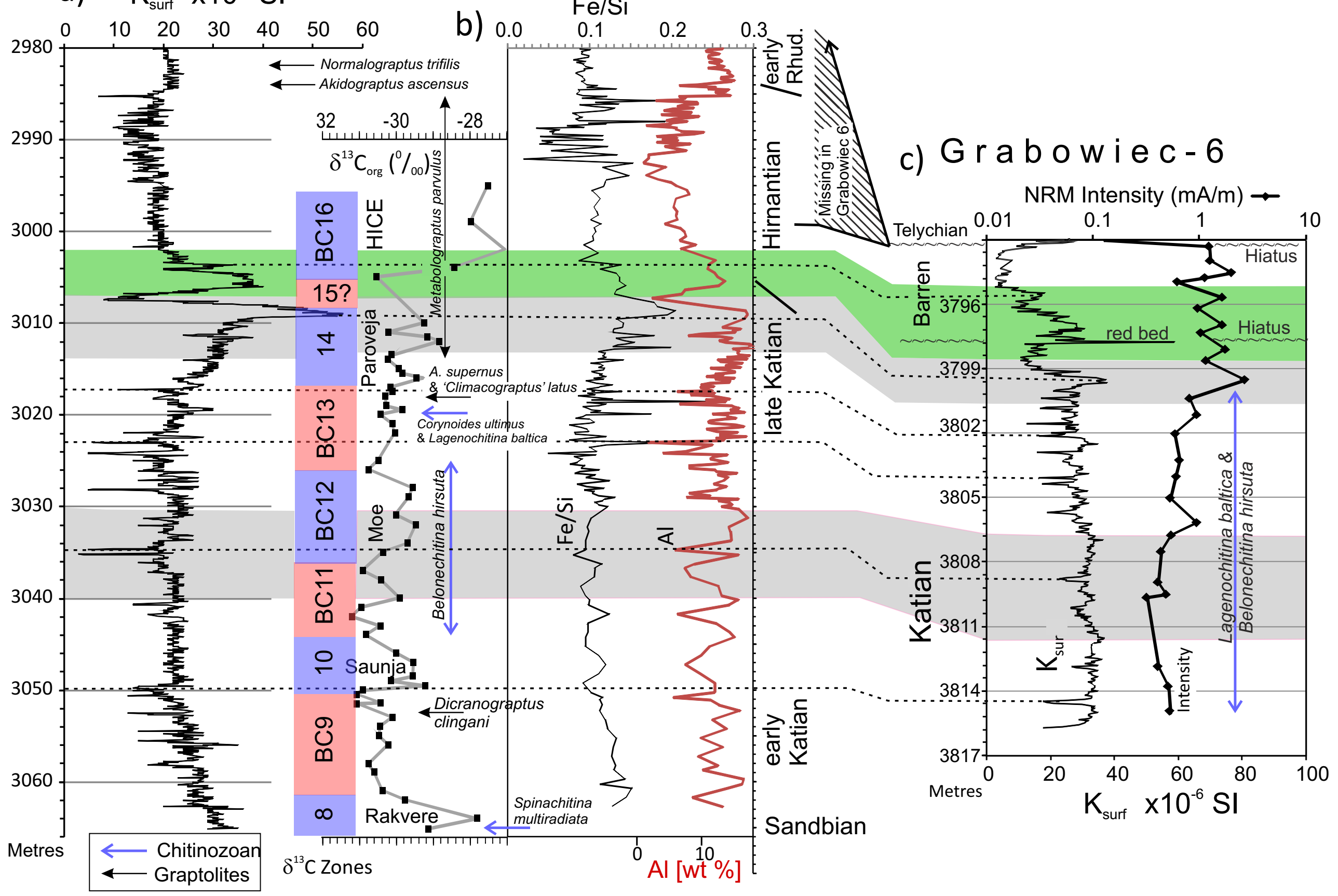

Fig. 5. 


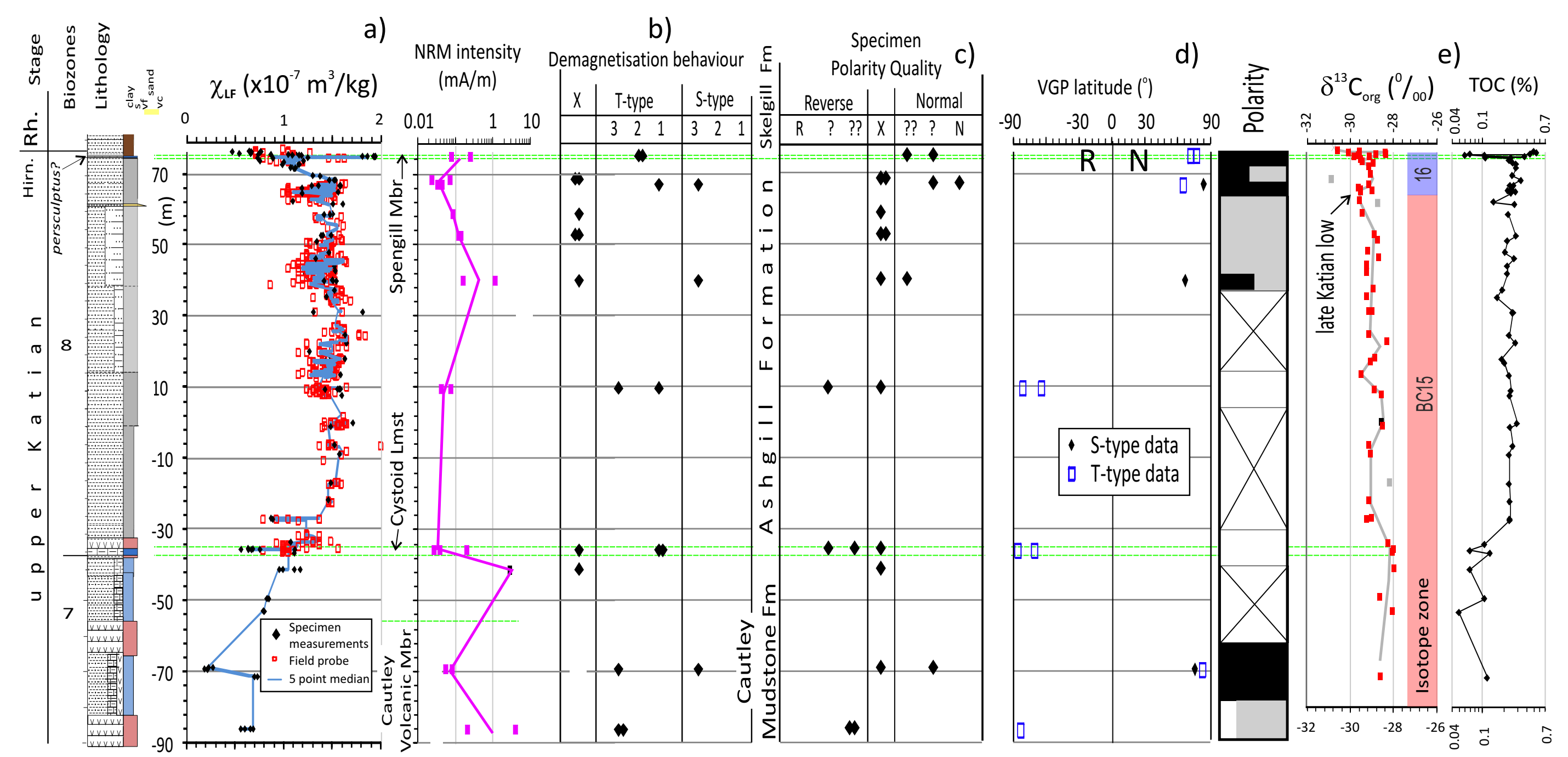

Fig. 6. 

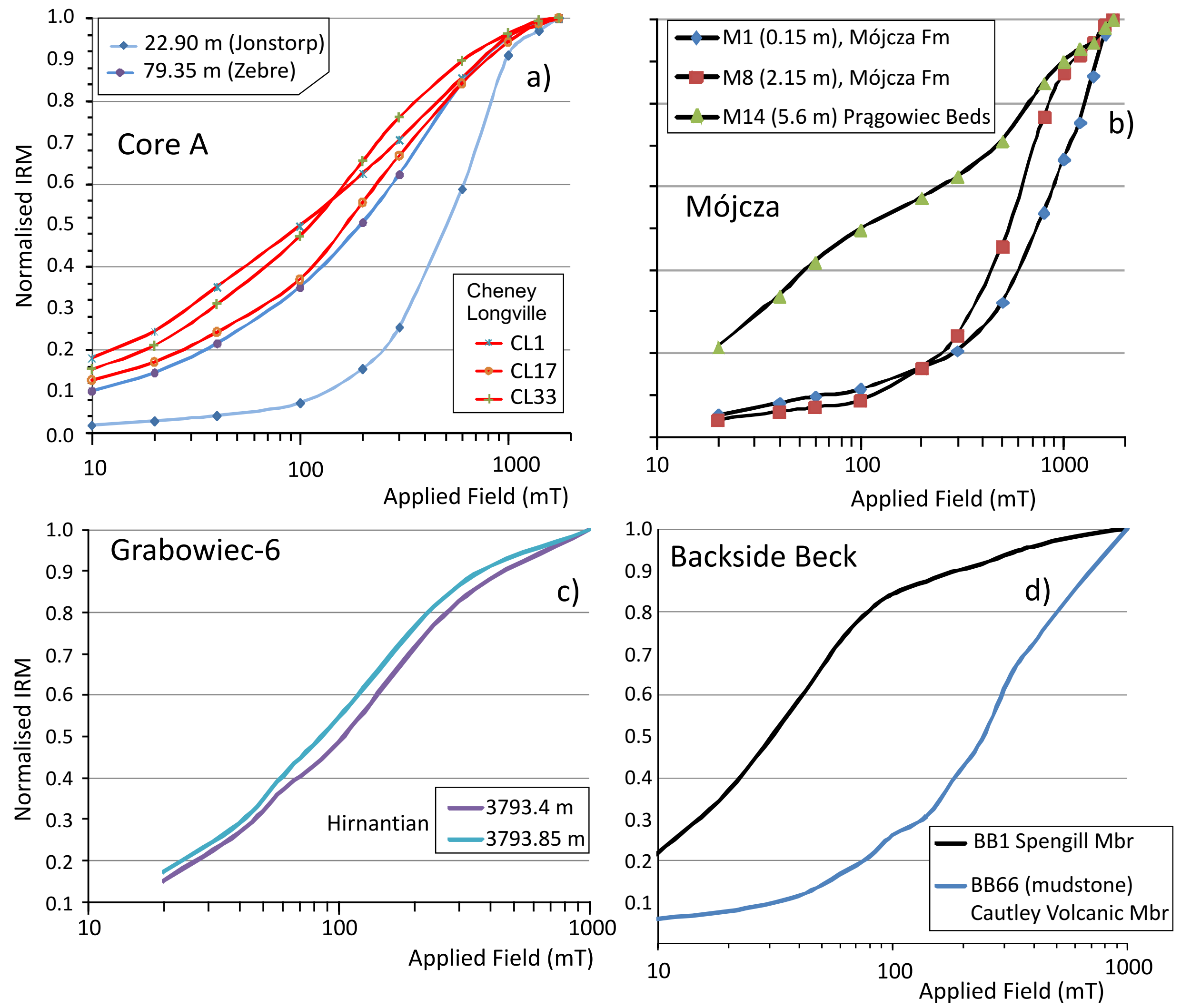

Fig. 7. 

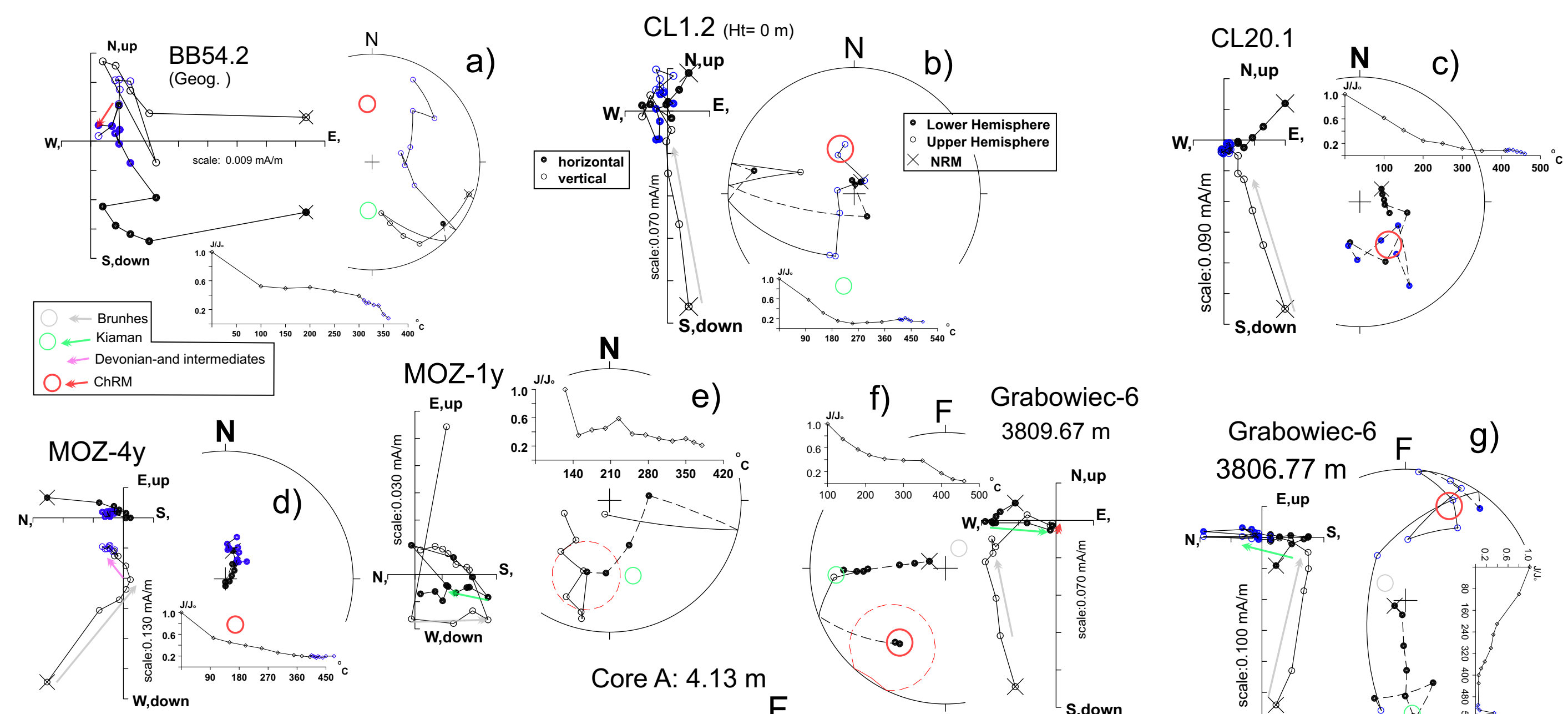

e)
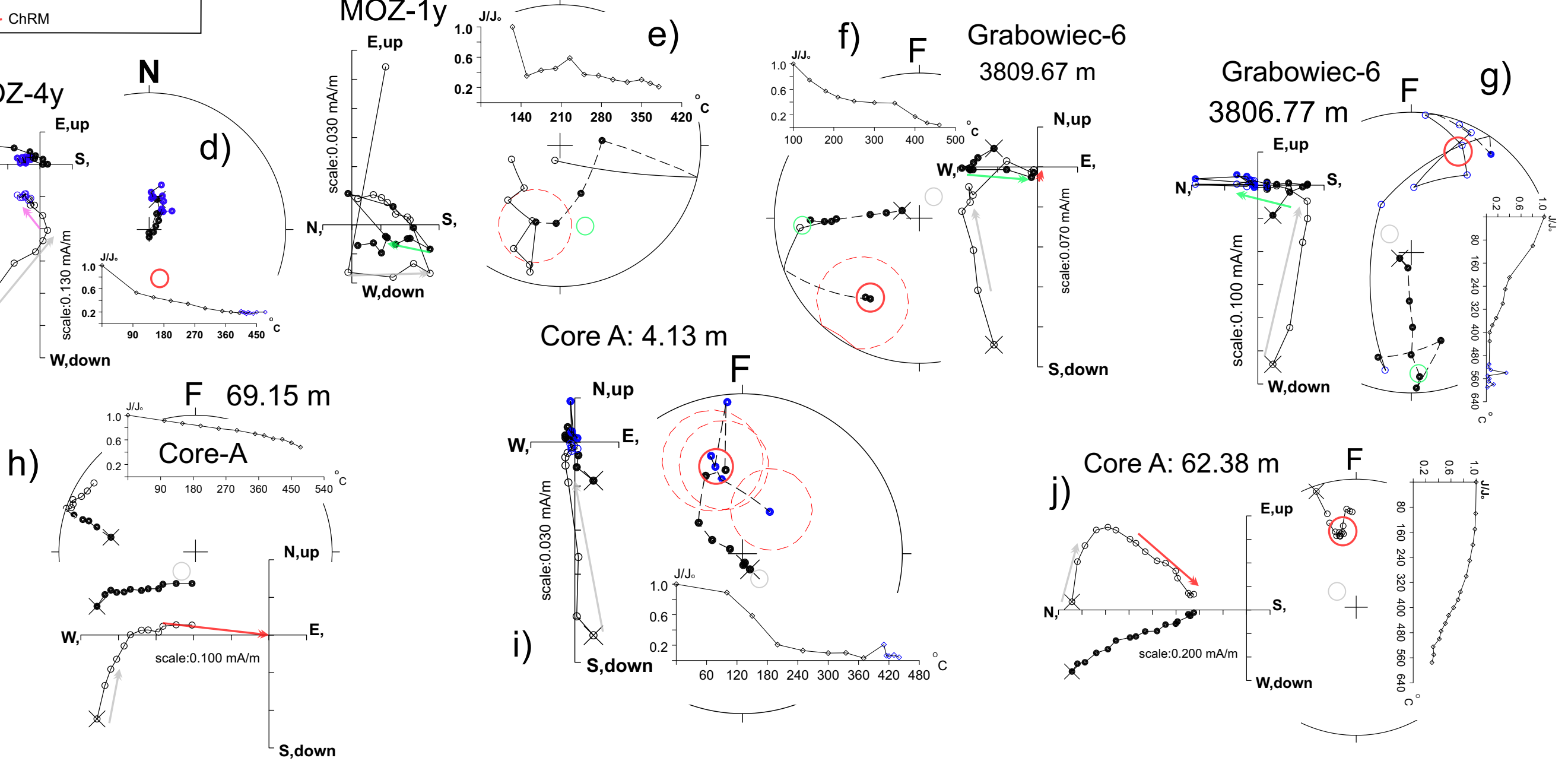

Fig. 8. 

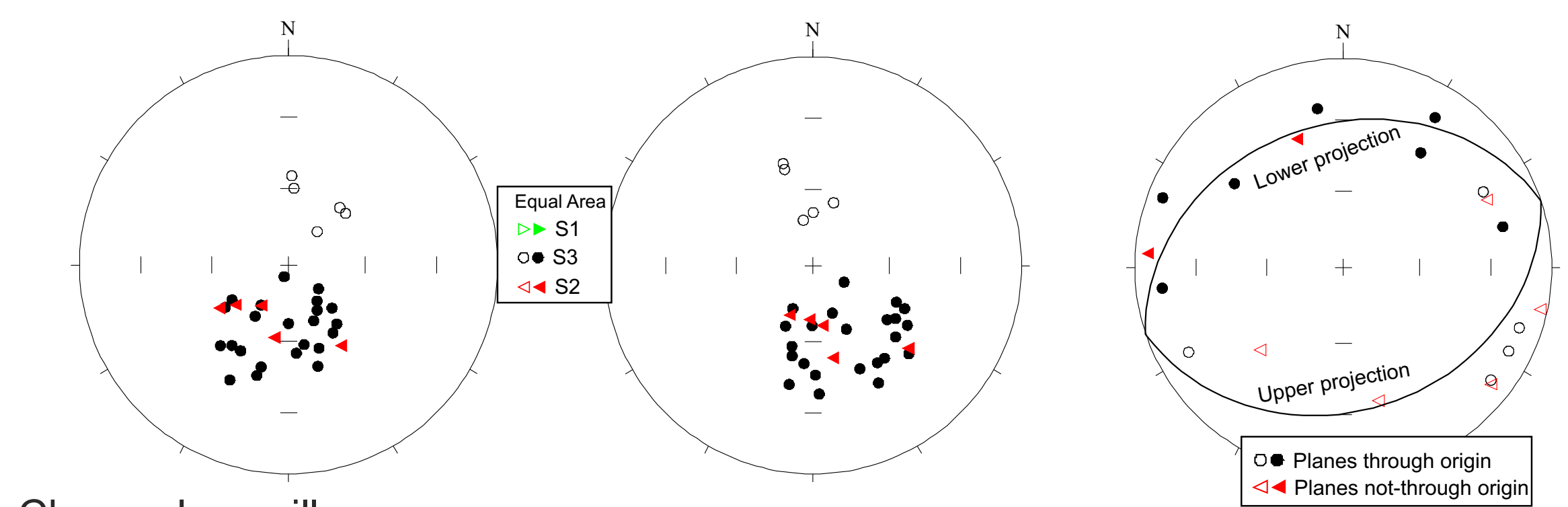

Cheney-Longville

-.--ChRM Insitu

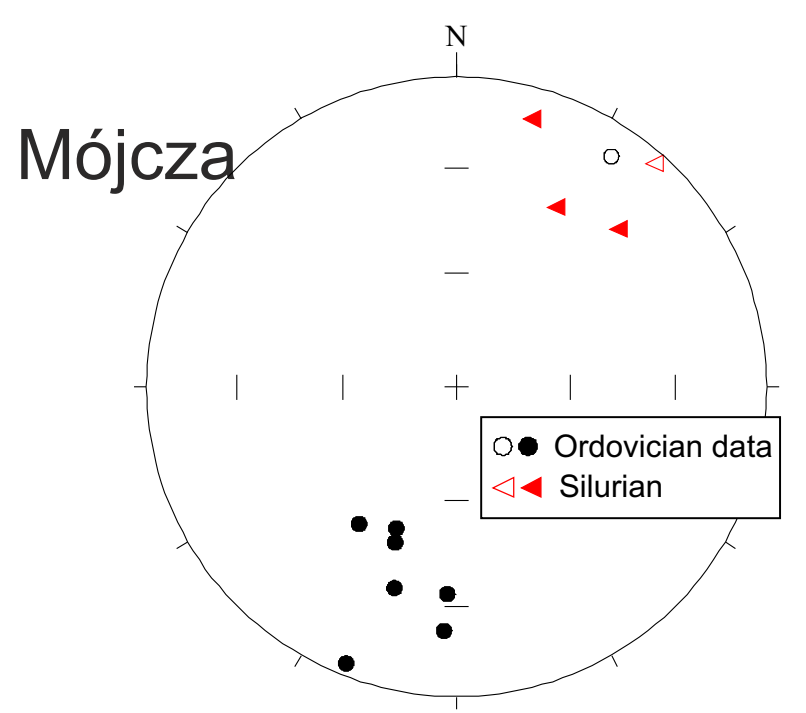

ChRM Stratigraphic-

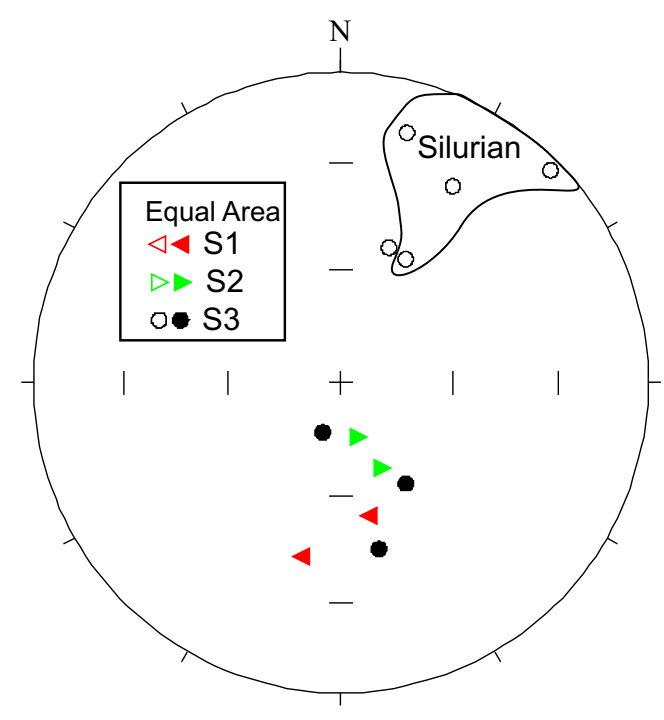

ChRM poles to great circles (strat. Coords)

Fig. 9. .

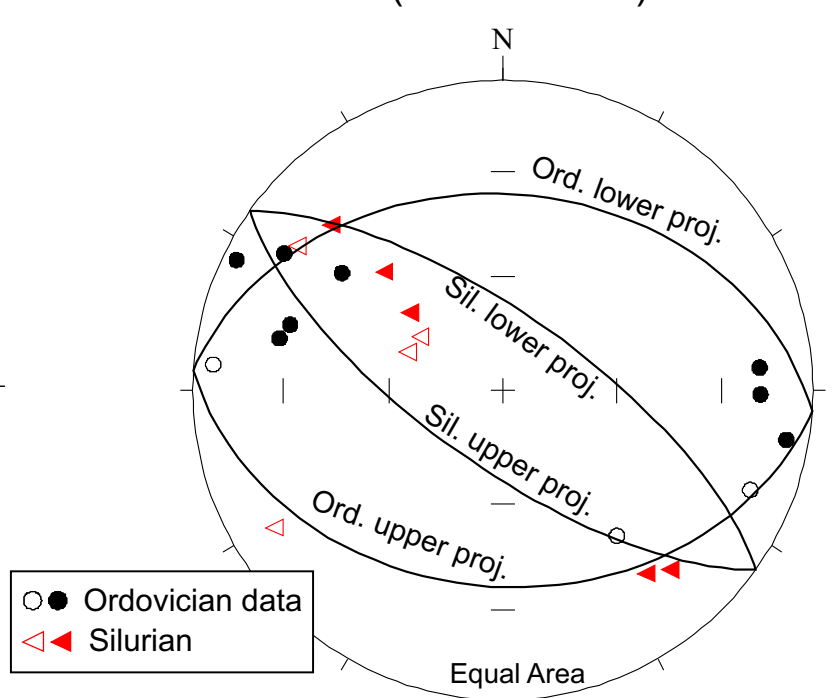




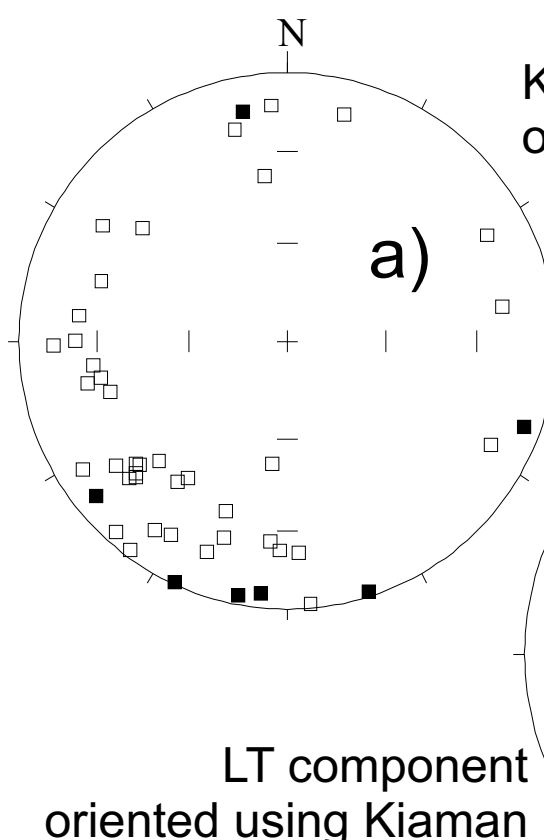

oriented using Kiaman

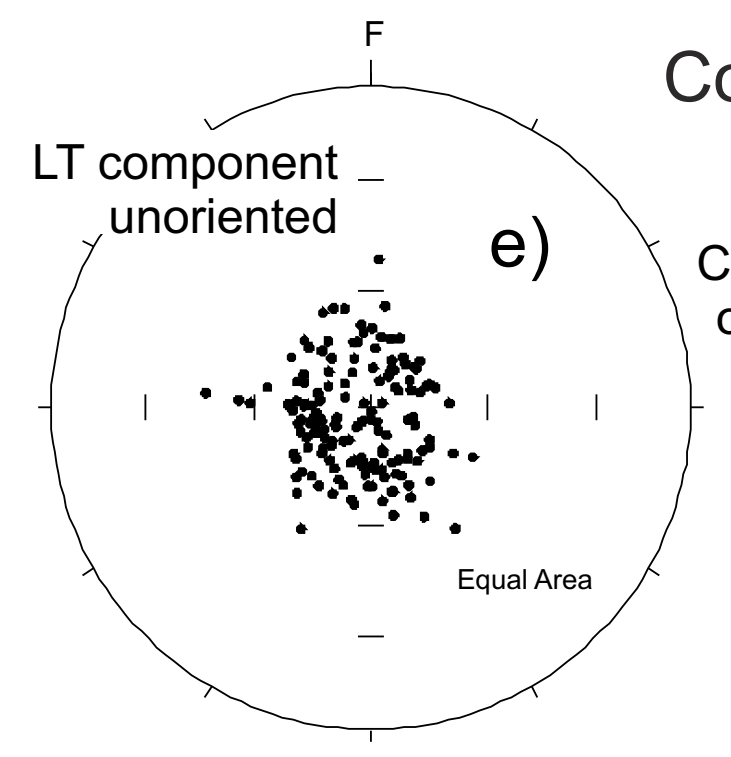

\section{Grabowiec-6}

Kiaman component oriented using LT
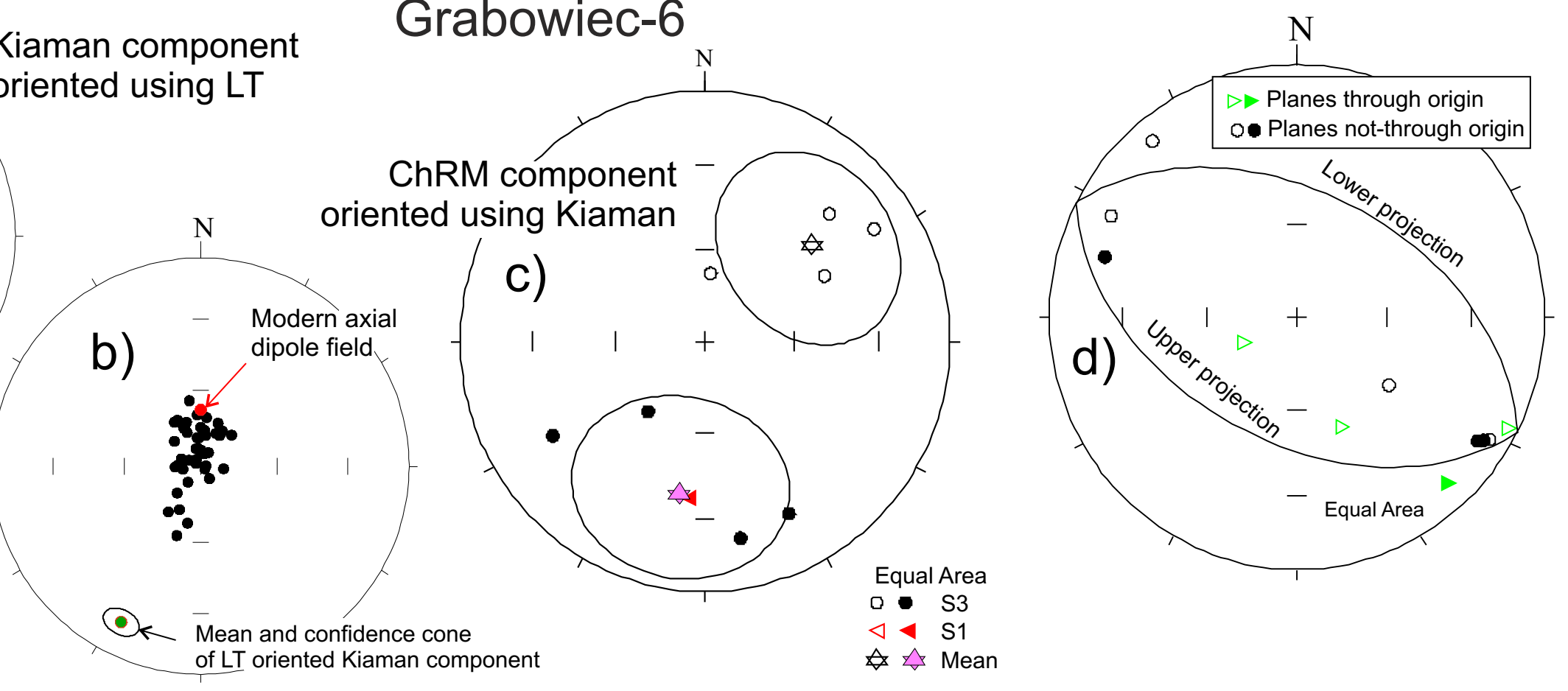

$\mathrm{N}$

\section{Core-A}

\section{(1)}

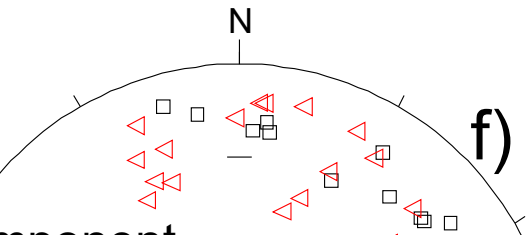

ChRM component oriented using LT $\square \bar{\triangleleft} \triangleleft \triangleleft \triangleleft \square$

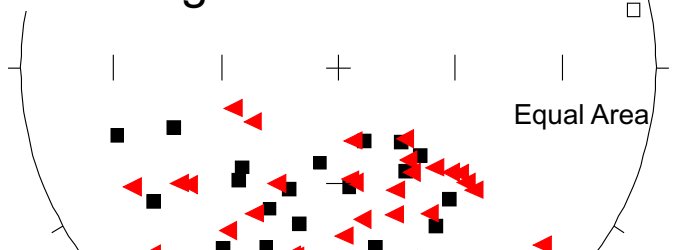

\begin{tabular}{|c|c|c|c|c|c|}
\hline $\begin{array}{l}\text { 9) } \\
\text { Interval }\end{array}$ & $\begin{array}{c}\text { Specimen } \\
\text { mean } \\
\text { depth } \\
(\mathrm{m})\end{array}$ & $\begin{array}{c}\text { Mean } \\
\text { inc }\end{array}$ & $\alpha 95$ & k & $\mathbf{n}$ \\
\hline Porkuni & -6.3 & 31.2 & 6.0 & 18.0 & 23 \\
\hline Pirgu & -19.9 & 27.6 & 4.7 & 22.3 & 29 \\
\hline Haljala-Vormsi & -35.2 & 38.6 & 8.7 & 12.3 & 17 \\
\hline Uhaku-Kukruse & -48.3 & 48.6 & 9.5 & 10.9 & 18 \\
\hline Kunda-Lasmanagi & -62.4 & 45.7 & 11 & 13.4 & 11 \\
\hline Volkov-Cambrian & -75.2 & 48.1 & 9.7 & 10.2 & 19 \\
\hline
\end{tabular}

Mean inclinations in Core-A :method of McFadden \& Reid (1982) 


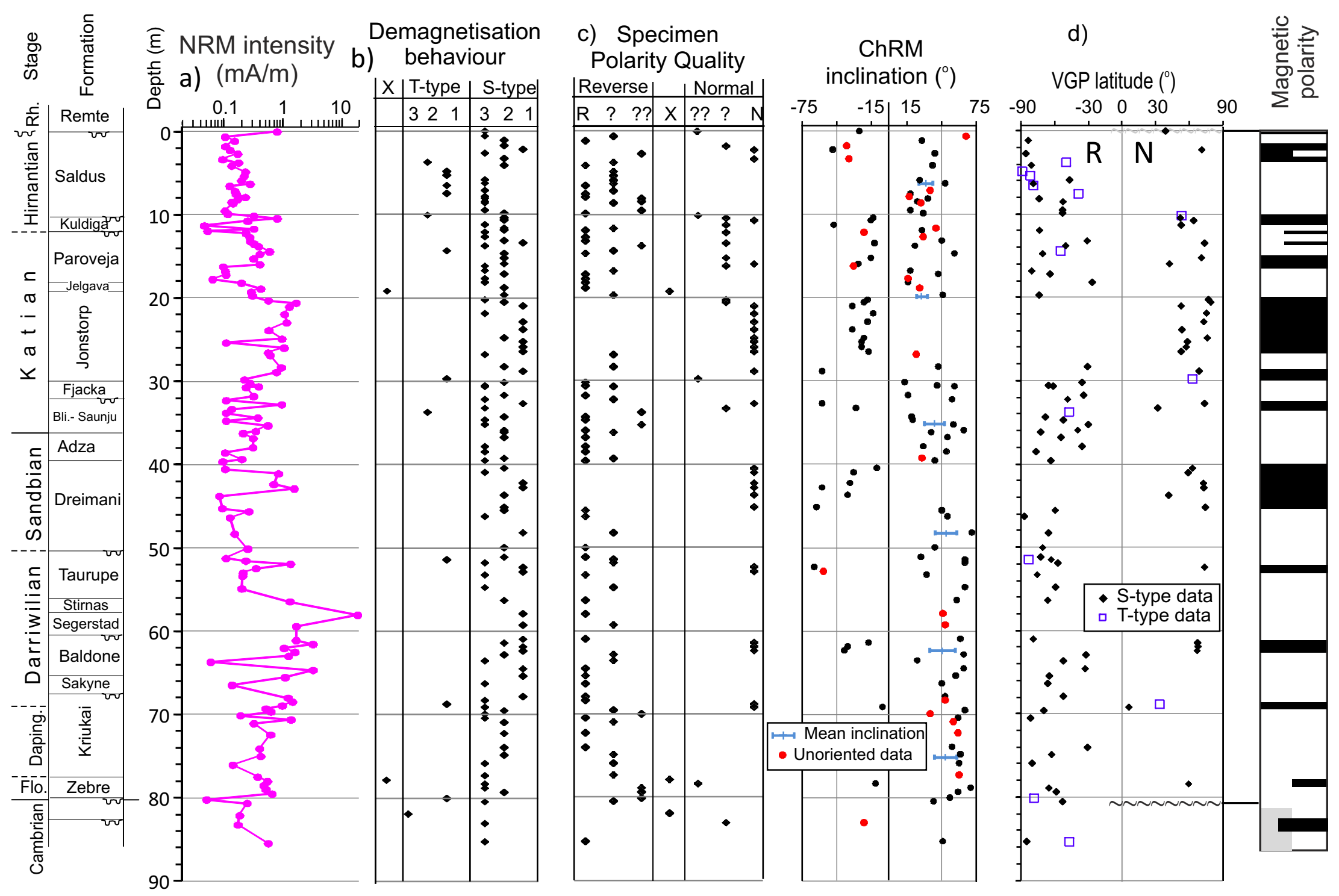

Fig. 11 


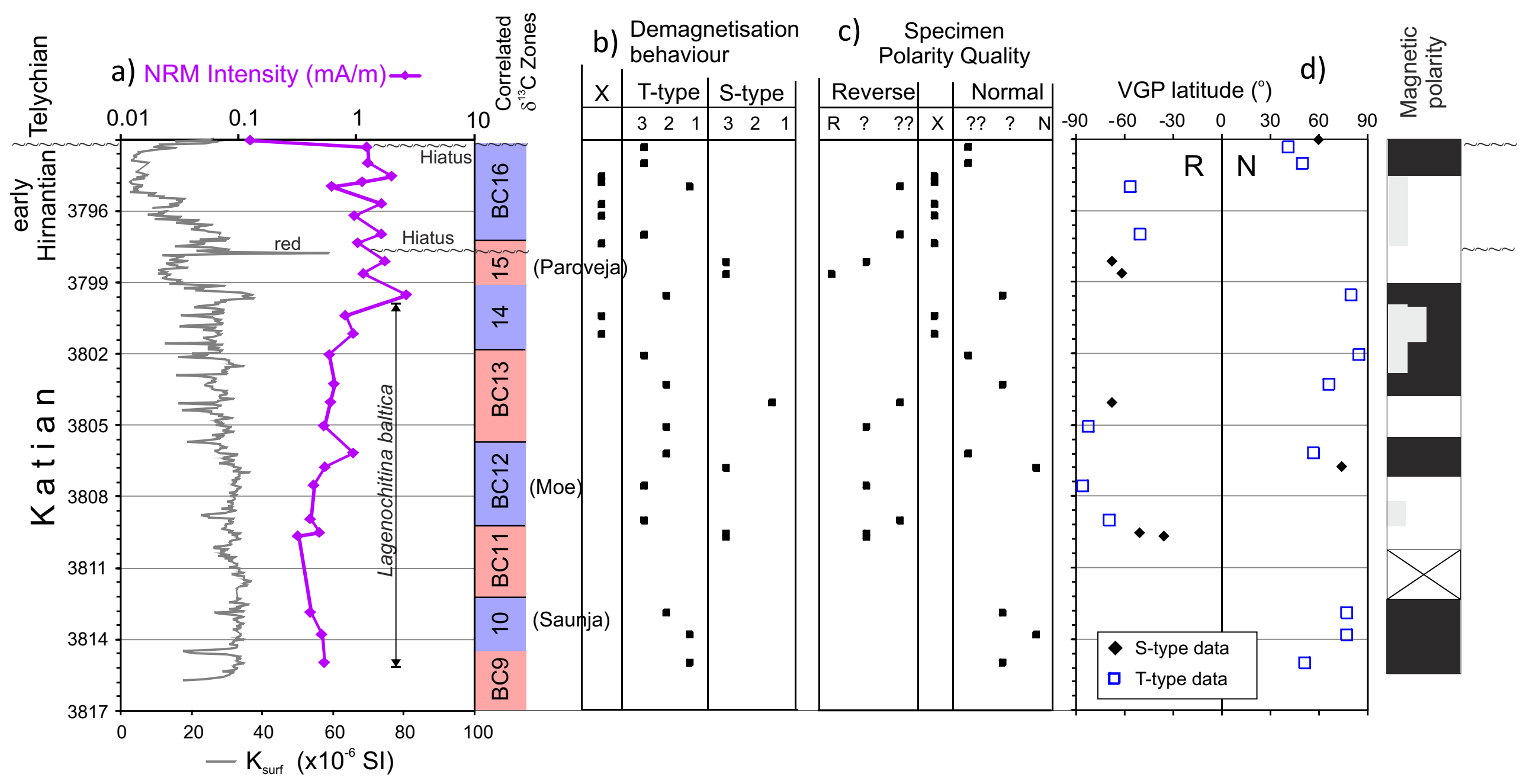

Fig. 12. 


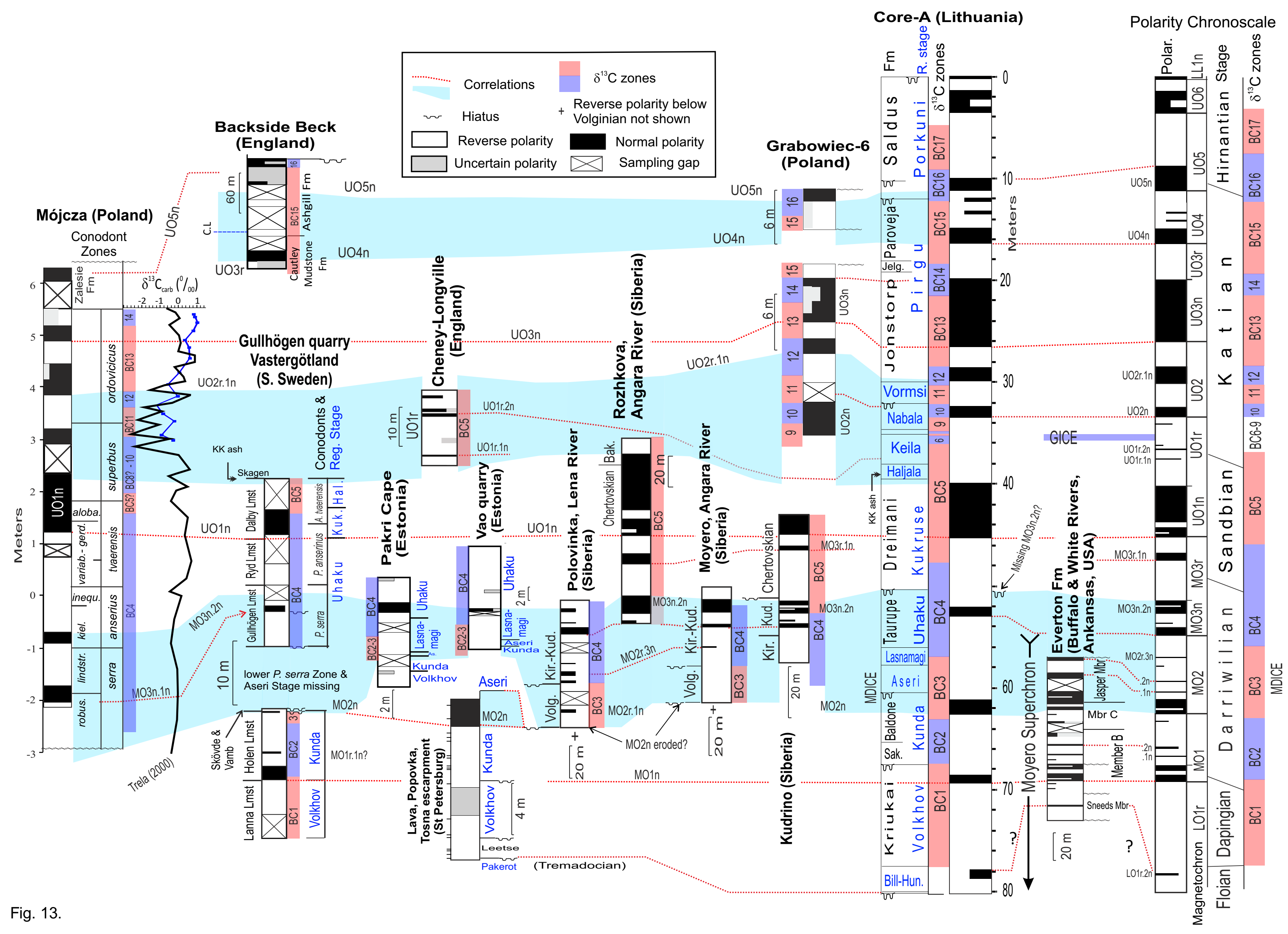




\section{Supplementary Information for: A geomagnetic polarity stratigraphy for the Middle and Upper Ordovician}

By: Mark W. Hounslow, Samuel, E. Harris, Krystian Wójcik, Jerzy Nawrocki, Kenneth T. Ratcliffe, Nigel H. Woodcock, Paul Montgomery

The supplementary information contains the following:

a) Details of sampling locations both on maps and in more detailed sedimentary logs (Figs. S1 to S3).

b) Additional rock magnetic data (Fig. S4).

c) Carbon isotope and organic matter concentration data for the Cheney Longville and Mójcza sections and Core-A (Tables S1, S2).

d) Anisotropy of magnetic susceptibility data for Grabowiec-6 (Fig. S5)

e) Palaeomagnetic overprint components from sections and cores (Figs. S6, S7).

f) Palaeomagnetic Ordovician ChRM components from the Backside Beck section show with the Silurian data from the section (Fig. S8).

g) Anisotropy of magnetic susceptibility (AMS) data for the Ordovician at Backside Beck (Fig. S9).

h) Additional data pertinent to the fold tests at Backside Beck (Figs. S10 to S13, Table S3).

i) Additional information about how the demagnetisation data was analysed with the LINEFIND software of Kent et al. (1983) (Fig. S14 to S16), and information on the statistics of the fitted lines and planes in Table S3.

j) Compilation of the palaeomagnetic data for each specimen from all sections (in the associated excel file). 


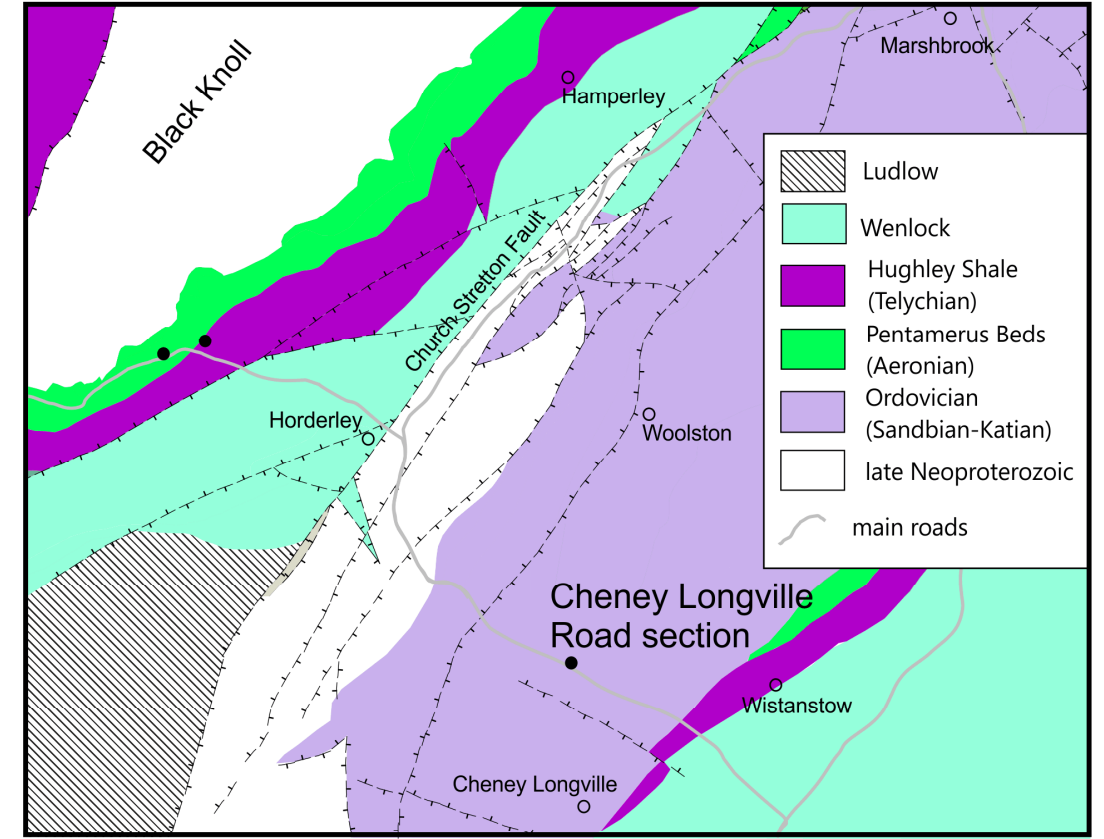

b)

$$
0 \quad 1 \quad 2 \mathrm{~km}
$$
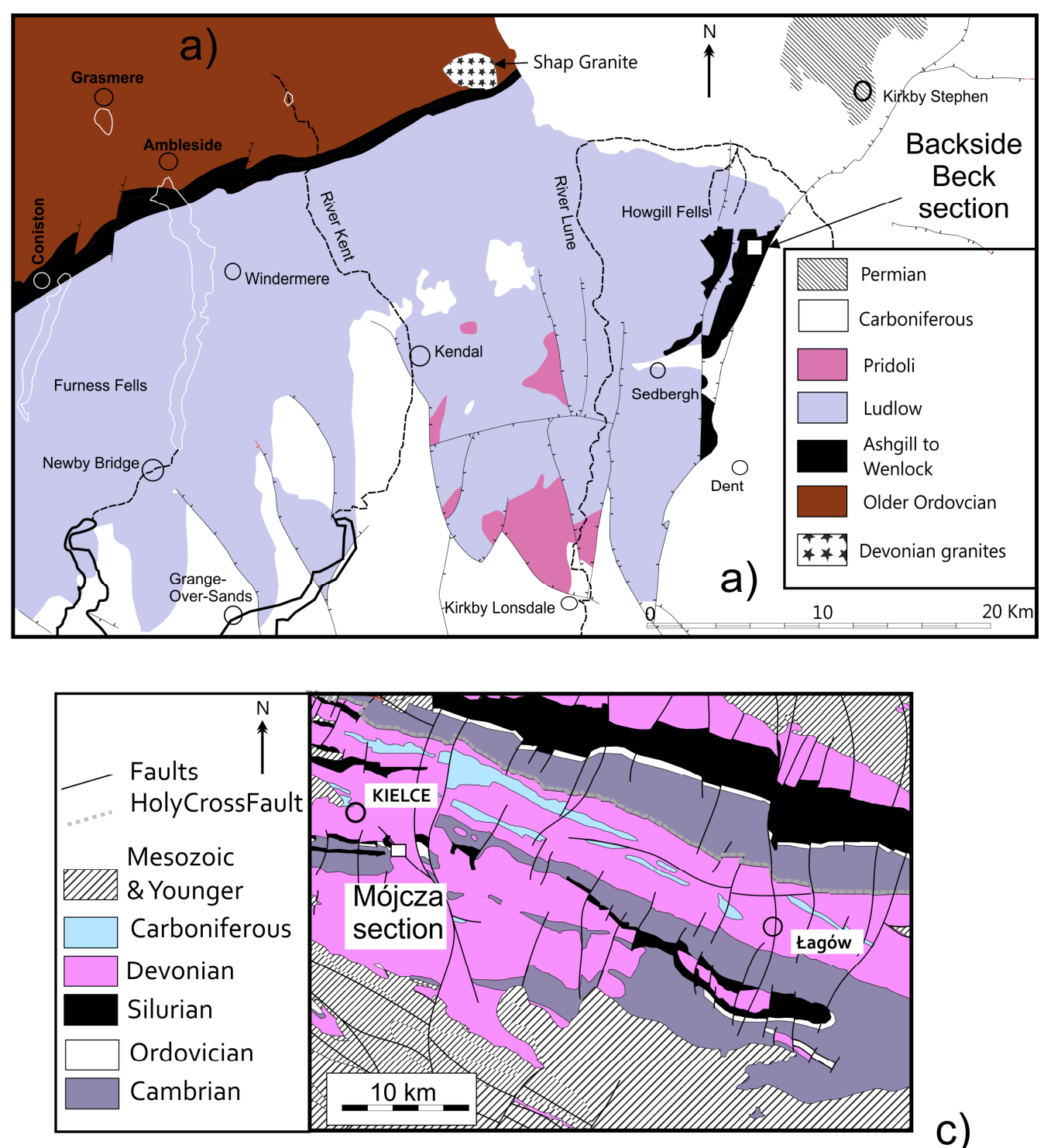

C)

Fig. S1. a),b) and c) Simplified geological maps of the sampling sites (unfilled squares in a and c). a) the Backside Beck section, Howgill Fells,UK, b) Cheney Longville road section, Shropshire, UK and c) Mójcza sections, Holy Cross Mountains, Poland; Holy Cross Mountain map after Rühle (1977), Kowalczewski et al. (1990). 


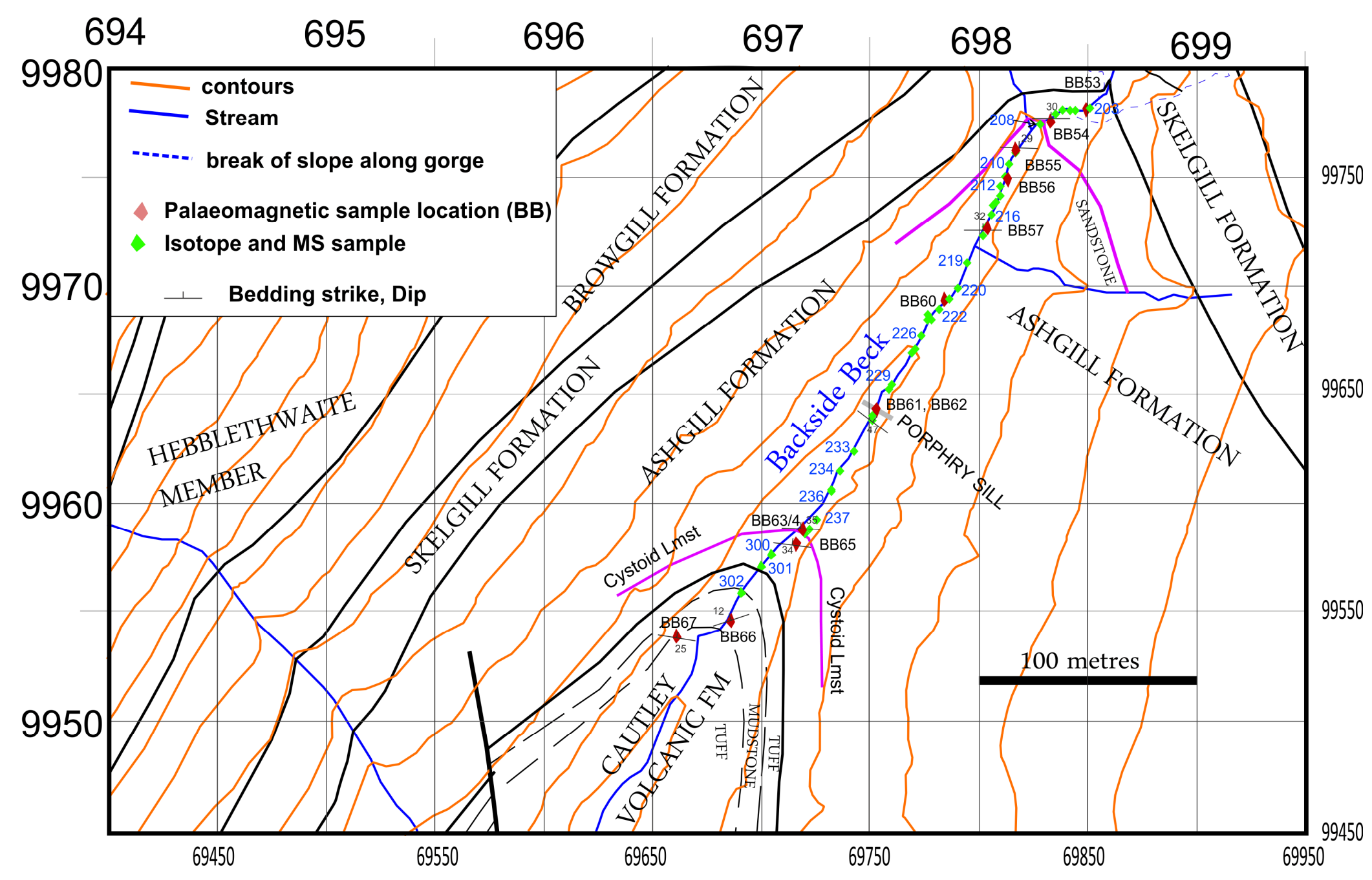

Fig. S2. Detail of the sampling locations of the palaeomagnetic and carbon isotope plus magnetic susceptibility (MS) samples in the Ordovician of the Backside Beck Section, UK. The coordinates are the British National Grid. The bedding strike displayed assumes the grid is true north-directed. Base geology map based on Woodcock and Rickards (2006). 

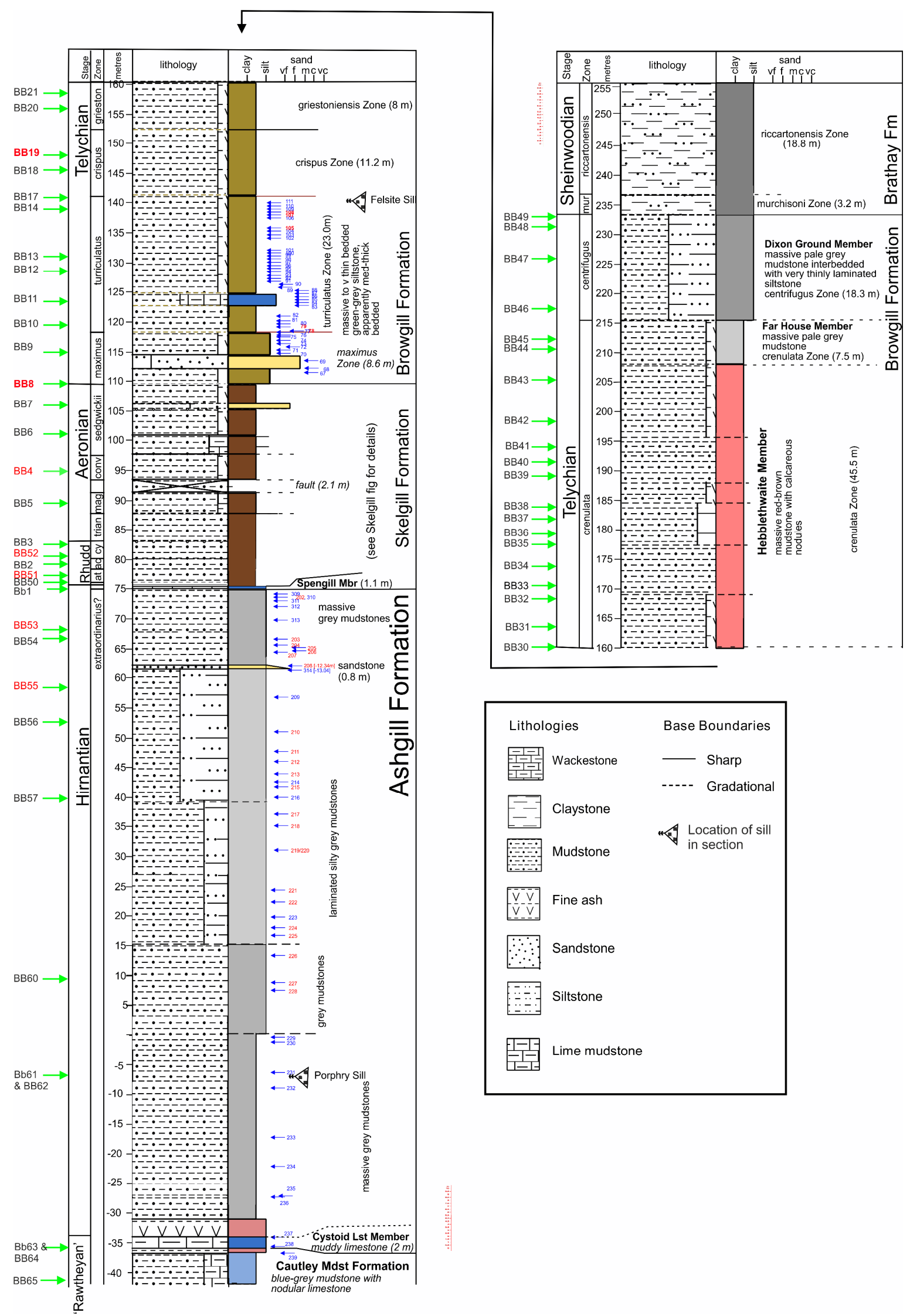

Fig. S3. Sampling positions of the palaeomagnetic (green arrows) and carbon isotope (blue arrows) samples in the log of the Backside Beck Section, UK. The carbon isotope and MS data from the Silurian part of the section and the Silurian palaeomagnetic data in Hounslow et al. (2021). Graptolite zones based on Rickards (1970, 1989), Woodcock \& Rickards (2006). 

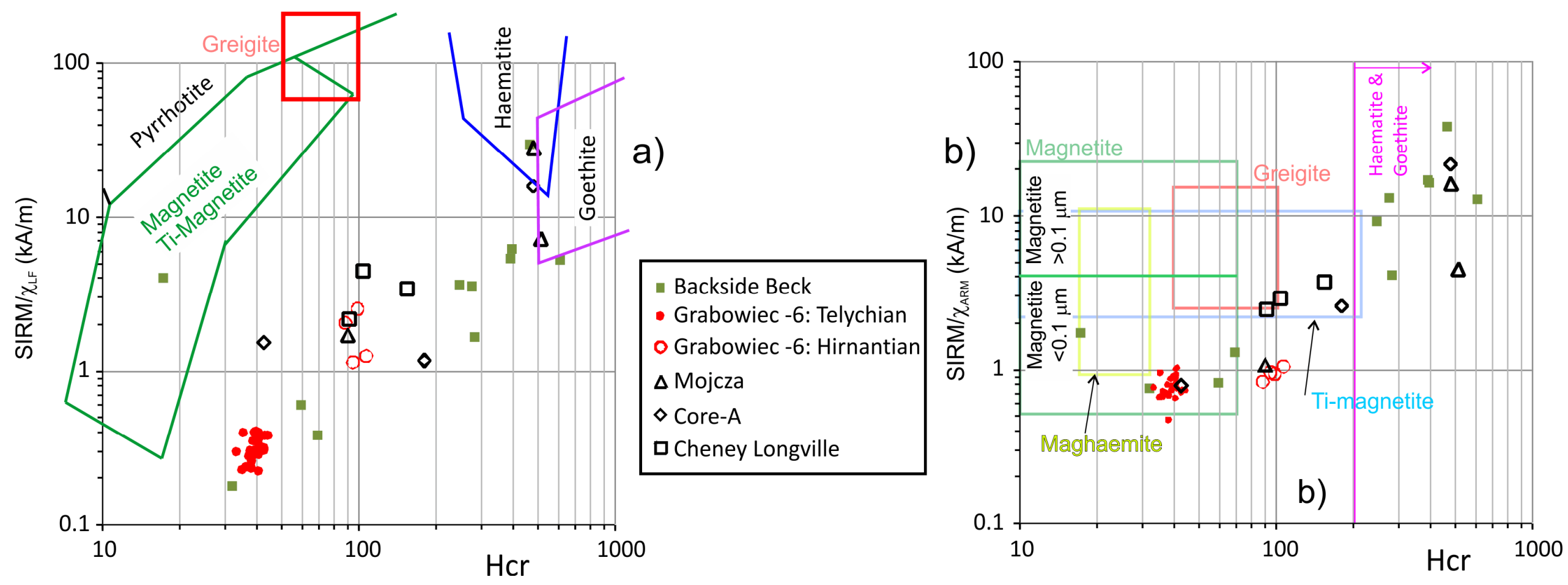

Fig. S4. Additional rock magnetic data. a) Data showing $H_{\mathrm{cr}}$ and SIRM/ $\chi_{\mathrm{LF}}$, along with the discrimination fields of Peters and Thompson (1998; based on natural minerals). The large range in $\mathrm{H}_{\mathrm{cr}}$ suggests haematite dominates and makes a substantial contribution in some samples (with $\mathrm{H}_{\mathrm{cr}}>0.2 \mathrm{~T}$, mostly red or reddish samples), and lower $\mathrm{H}_{\mathrm{cr}}(<0.1 \mathrm{~T})$ in other drab coloured lithologies. Intermediate $\mathrm{H}_{\mathrm{cr}}$ likely indicates mixtures between these two extremes. Our $\mathrm{H}_{\mathrm{cr}}$ data $<100 \mathrm{mT}$ falls largely outside magnetite or magnetic sulphide envelopes in a), due to a substantial paramagnetic contribution to $\chi_{L F}$, which lowers the SIRM/ $\chi_{L F}$ by a factor of $1 /(1-p \%)$, where $\% p$ is the paramagnetic contribution to $\chi_{L F}$. B) $H_{c r}$ and SIRM/ $\chi_{A R M}$ data with the coloured boxes demarcating the limits of these parameters for different minerals (natural and synthetics) from Peters and Dekkers (2003). Using this data it seems most likely that magnetite is the low $H_{\mathrm{cr}}$ mineral with probable particle sizes $<0.1 \mu \mathrm{m}$. 
Ordovician polarity stratigraphy: SI,Pg.6

\begin{tabular}{|c|c|c|c|c|}
\hline Sample code & $\begin{array}{c}\text { \%Nitrogen } \\
\text { (wt\%) }\end{array}$ & \%Carbon (wt\%) & $\begin{array}{c}\delta^{13} C_{\text {org }} \text { VPDB } \\
(\% 00)\end{array}$ & Height (m) \\
\hline \multicolumn{5}{|c|}{ Cheney Longville } \\
\hline CL-33 & 0.02 & 0.05 & -28.38 & 18.83 \\
\hline CL-31 & 0.01 & 0.02 & -26.18 & 17.35 \\
\hline CL-28 & 0.02 & 0.04 & -26.46 & 15.46 \\
\hline CL-26 & 0.02 & 0.03 & -26.69 & 13.93 \\
\hline CL-23 & 0.04 & 0.08 & -26.24 & 12.05 \\
\hline$C L-22$ & 0.03 & 0.06 & -26.78 & 11.32 \\
\hline$C L-20$ & 0.03 & 0.05 & -26.59 & 10.23 \\
\hline CL-19 & 0.02 & 0.03 & -25.80 & 9.24 \\
\hline CL-16 & 0.02 & 0.03 & -26.12 & 6.94 \\
\hline CL-15 & 0.02 & 0.04 & -26.22 & 6.21 \\
\hline CL-11 & 0.02 & 0.05 & -26.50 & 4.67 \\
\hline CL-8 & 0.08 & 0.76 & -26.45 & 3.36 \\
\hline CL-6 & 0.02 & 0.06 & -26.39 & 2.55 \\
\hline CL-5 & 0.02 & 0.03 & -26.08 & 2.07 \\
\hline CL-3 & 0.03 & 0.10 & -29.34 & 0.59 \\
\hline CL-1 & 0.02 & 0.05 & -26.17 & 0.00 \\
\hline \multicolumn{5}{|c|}{ Backside Beck Ordovician: Cautley Mudstone Fm, Ashgill Fm, Spengill Mbr. } \\
\hline 304 & 0.08 & 0.07 & -28.37 & 75.45 \\
\hline 305 & 0.08 & 0.06 & -28.33 & 75.40 \\
\hline 306 & 0.08 & 0.11 & -28.82 & 75.20 \\
\hline 307 & 0.09 & 0.38 & -29.59 & 74.75 \\
\hline 308 & 0.10 & 0.25 & -29.09 & 74.45 \\
\hline 311 & 0.12 & 0.29 & -28.94 & 72.72 \\
\hline 312 & 0.11 & 0.29 & -29.15 & 71.74 \\
\hline 313 & 0.11 & 0.26 & -29.04 & 69.43 \\
\hline 314 & 0.10 & 0.28 & -28.74 & 61.40 \\
\hline BB56 & 0.09 & 0.29 & -28.90 & 52.60 \\
\hline 229 & 0.09 & 0.30 & -28.56 & -0.27 \\
\hline 237 & 0.05 & 0.11 & -28.25 & -34.08 \\
\hline BB64 & 0.04 & 0.07 & -28.00 & -35.80 \\
\hline 239 & 0.05 & 0.13 & -28.03 & -36.63 \\
\hline BB65 & 0.04 & 0.07 & -27.94 & -41.30 \\
\hline 300 & 0.04 & 0.11 & -28.64 & -49.36 \\
\hline 301 & 0.03 & 0.05 & -28.05 & -53.11 \\
\hline 302 & 0.05 & 0.12 & -28.58 & -71.52 \\
\hline 3 & - & 0.11 & -29.83 & 74.70 \\
\hline 2 & - & 0.24 & -29.54 & 73.70 \\
\hline 202 & - & 0.26 & -29.45 & 73.27 \\
\hline BB 53 & - & 0.34 & -30.89 & 68.30 \\
\hline BB 54 & - & 0.24 & -33.55 & 66.76 \\
\hline 203 & - & 0.27 & -29.13 & 66.65 \\
\hline 204 & - & 0.25 & -29.61 & 65.66 \\
\hline 205 & - & 0.23 & -29.53 & 65.28 \\
\hline 206 & - & 0.28 & -28.97 & 64.90 \\
\hline 207 & - & 0.25 & -29.54 & 64.60 \\
\hline 208 & - & 0.15 & -29.57 & 62.16 \\
\hline BB 55 & - & 0.23 & -29.45 & 58.52 \\
\hline 210 & - & 0.22 & -28.73 & 51.10 \\
\hline 211 & - & 0.21 & -29.17 & 47.88 \\
\hline
\end{tabular}


Ordovician polarity stratigraphy: SI,Pg.7

\begin{tabular}{|c|c|c|c|c|}
\hline 212 & - & 0.28 & -28.68 & 46.23 \\
\hline 213 & - & 0.22 & -29.22 & 44.12 \\
\hline 215 & - & 0.22 & -29.22 & 41.94 \\
\hline 217 & - & 0.19 & -28.91 & 37.35 \\
\hline 218 & - & 0.16 & -29.24 & 35.33 \\
\hline 219 & - & 0.27 & -28.99 & 31.13 \\
\hline 220 & - & 0.26 & -29.13 & 31.13 \\
\hline 221 & - & 0.23 & -29.14 & 24.50 \\
\hline 222 & - & 0.29 & -28.30 & 22.42 \\
\hline 224 & - & 0.19 & -28.83 & 18.09 \\
\hline 225 & - & 0.21 & -29.05 & 16.78 \\
\hline 226 & - & 0.24 & -29.49 & 13.41 \\
\hline 227 & - & 0.25 & -28.89 & 9.01 \\
\hline 228 & - & 0.24 & -28.56 & 7.70 \\
\hline 230 & - & 0.24 & -28.50 & -1.21 \\
\hline 231 & - & 0.26 & -29.13 & -6.48 \\
\hline 232 & - & 0.24 & -29.04 & -8.92 \\
\hline 233 & - & 0.24 & -28.18 & -17.19 \\
\hline 234 & - & 0.24 & -29.13 & -22.09 \\
\hline 235 & - & 0.24 & -29.00 & -27.10 \\
\hline 236 & - & 0.24 & -29.22 & -27.31 \\
\hline Sample code & & \%TOC (wt\%) & $\begin{array}{c}\delta^{13} C_{\text {org }} \text { VPDB } \\
(\% \circ)\end{array}$ & Height (m) \\
\hline \multicolumn{5}{|l|}{ Core-A } \\
\hline CA-1 & - & 2.28 & -28.12 & 14.41 \\
\hline CA-2 & - & 6.30 & -30.00 & 14.24 \\
\hline CA-3 & - & 3.92 & -28.86 & 13.37 \\
\hline CA-4 & - & 6.63 & -29.03 & 12.77 \\
\hline CA-5 & - & 0.53 & -28.22 & 12.43 \\
\hline CA-6 & - & 1.87 & -28.60 & 11.65 \\
\hline CA-7 & - & 1.70 & -28.73 & 11.59 \\
\hline CA-8 & - & 1.28 & -28.67 & 11.35 \\
\hline CA-9 & - & 3.00 & -29.31 & 10.60 \\
\hline CA-10 & - & 9.73 & -29.90 & 6.54 \\
\hline CA-11 & - & 6.64 & -29.92 & 5.76 \\
\hline CA-12 & - & 5.98 & -29.84 & 5.45 \\
\hline CA-13 & - & 2.18 & -29.28 & 5.28 \\
\hline CA-14 & - & 1.23 & -30.13 & 4.85 \\
\hline CA-15 & - & 3.21 & -30.61 & 4.50 \\
\hline CA-16 & - & 1.30 & -29.96 & 2.44 \\
\hline CA-17 & - & 2.72 & -30.59 & -30.49 \\
\hline CA-18 & - & 2.37 & -30.66 & -30.72 \\
\hline CA-19 & - & 6.78 & -30.06 & -31.00 \\
\hline CA-20 & - & 3.43 & -29.81 & -31.55 \\
\hline CA-21 & - & 0.59 & -24.65 & -31.69 \\
\hline CA-22 & - & 0.44 & -29.01 & -35.10 \\
\hline CA-23 & - & 0.81 & -28.99 & -35.35 \\
\hline
\end{tabular}

Table S1. Organic carbon isotope data. At Backside Beck, the top of the Cystoid Lmst Mbr=-33.9 m; base of the Ashgill Fm sandstone $=61.5 \mathrm{~m}$; base of the Spengill $\mathrm{Mbr}=74.5 \mathrm{~m}$; base of the Silurian=75.5 m. Sample codes in red measured using methods in Sullivan et al. (2018). Sample codes for Backside Beck samples shown in Figs. S2 and S3. Others relate to depths/heights shown in main text figures. 


\begin{tabular}{|c|c|c|c|}
\hline Sample code & $\begin{array}{l}\delta^{13} C_{\text {carb }} \text { VPDB } \\
(\% / 00)\end{array}$ & $\begin{array}{l}\delta^{18} O_{\text {carb }} \\
\operatorname{VPDB}(\% 0)\end{array}$ & Height \\
\hline \multicolumn{4}{|l|}{ Mójcza } \\
\hline$M Z-9 b$ & 0.84 & -4.54 & 2.50 \\
\hline MZ-9a & 0.91 & -4.98 & 2.45 \\
\hline MZ-8b & 1.04 & -3.97 & 2.34 \\
\hline MZ-7g & 0.81 & -4.01 & 2.18 \\
\hline MZ-7d & 0.36 & -4.005 & 2.00 \\
\hline$M Z-7 b$ & 0.575 & -4.455 & 1.86 \\
\hline MZ-7 & 0.62 & -4.58 & 1.65 \\
\hline MZ-6b & 0.05 & -3.93 & 1.37 \\
\hline MZ-5c & -0.56 & -4.71 & 1.15 \\
\hline MZ-4d & -0.04 & -4.205 & 0.92 \\
\hline$M Z-4 b$ & -1.19 & -4.78 & 0.75 \\
\hline MZ-3a & -0.84 & -4.69 & 0.58 \\
\hline MZ-2 & -0.23 & $\begin{array}{l}-3.98 \\
\end{array}$ & 0.44 \\
\hline MZ-1a & -0.92 & -3.89 & 0.17 \\
\hline MZ-0 & -0.29 & -3.85 & 0.07 \\
\hline \multicolumn{4}{|l|}{ Core-A } \\
\hline CA_C-13 & 1.12 & -6.61 & 2.74 \\
\hline CA_C-14 & 1.22 & -5.09 & 1.38 \\
\hline CA_C-15 & 1.20 & -6.23 & 0.77 \\
\hline CA_C-16 & 1.11 & -6.47 & 0.28 \\
\hline CA_C-17 & 0.36 & -4.66 & -0.03 \\
\hline CA_C-18 & 0.26 & -5.87 & -0.65 \\
\hline CA_C-19 & 0.09 & -7.74 & -1.15 \\
\hline CA_C-20 & 0.63 & -5.37 & -1.79 \\
\hline CA_C-21 & 0.80 & -5.62 & -2.24 \\
\hline CA_C-22 & 0.84 & -5.73 & -2.70 \\
\hline CA_C-23 & 0.84 & -7.87 & -3.35 \\
\hline CA_C-24 & 1.09 & -6.58 & -3.76 \\
\hline CA_C-25 & 1.28 & -5.06 & -4.13 \\
\hline CA_C-26 & 1.20 & -5.91 & -4.85 \\
\hline CA_C-27 & 1.11 & -7.51 & -5.35 \\
\hline CA_C-28 & 1.29 & -6.49 & -5.90 \\
\hline CA_C-29 & 1.40 & -5.86 & -6.30 \\
\hline CA_C-30 & 1.53 & -5.56 & -6.55 \\
\hline CA_C-31 & 0.96 & -9.53 & -7.15 \\
\hline CA_C-32 & 1.77 & -4.84 & -7.55 \\
\hline CA_C-33 & 1.81 & -4.53 & -7.88 \\
\hline CA_C-34 & 1.94 & -6.00 & -8.12 \\
\hline CA_C-35 & 2.29 & -5.27 & -8.48 \\
\hline CA_C-36 & 2.49 & -5.10 & -8.65 \\
\hline CA_C-37 & 3.50 & -4.92 & -9.52 \\
\hline CA_C-38 & 3.30 & -6.16 & -9.88 \\
\hline CA_C-39 & 2.51 & -5.32 & -10.13 \\
\hline CA_C-40 & 3.21 & -7.46 & -10.43 \\
\hline CA_C-41 & 3.12 & -7.88 & -10.72 \\
\hline CA_C-42 & 2.56 & -6.04 & -11.68 \\
\hline CA_C-43 & 3.69 & -6.39 & -11.92 \\
\hline CA C-44 & 1.70 & -4.70 & -12.18 \\
\hline
\end{tabular}


Ordovician polarity stratigraphy: SI,Pg.9

\begin{tabular}{|c|c|c|c|}
\hline CA_C-45 & 1.36 & -6.11 & -16.22 \\
\hline CA_C-46 & 1.24 & -6.75 & -17.72 \\
\hline CA_C-47 & 1.29 & -5.52 & -18.16 \\
\hline CA_C-48 & 1.47 & -5.09 & -18.85 \\
\hline CA_C-49 & 1.52 & -5.48 & -28.30 \\
\hline CA_C-50 & 1.01 & -4.81 & -33.74 \\
\hline CA_C-51 & 1.24 & -3.48 & -34.68 \\
\hline CA_C-52 & 0.67 & -5.84 & -39.28 \\
\hline CA_C-53 & 0.26 & -6.85 & -46.80 \\
\hline CA_C-54 & 0.22 & -6.14 & -48.22 \\
\hline CA_C-55 & 0.47 & -6.24 & -49.65 \\
\hline CA_C-56 & 0.81 & -6.76 & -51.14 \\
\hline CA_C-57 & 0.98 & -6.33 & -52.88 \\
\hline CA_C-58 & 0.96 & -6.72 & -53.27 \\
\hline CA_C-59 & 1.00 & -6.49 & -54.78 \\
\hline CA_C-60 & 1.30 & -5.77 & -56.32 \\
\hline CA_C-61 & 1.60 & -6.11 & -57.44 \\
\hline CA_C-62 & 1.49 & -5.79 & -58.39 \\
\hline CA_C-63 & 1.70 & -5.51 & -58.89 \\
\hline CA_C-64 & 1.53 & -6.28 & -59.30 \\
\hline CA_C-65 & 1.76 & -5.34 & -60.07 \\
\hline CA_C-66 & 1.59 & -6.82 & -60.52 \\
\hline CA_C-67 & 1.40 & -5.66 & -60.98 \\
\hline CA_C-68 & 1.22 & -6.12 & -61.43 \\
\hline CA_C-69 & 1.36 & -5.32 & -61.90 \\
\hline CA_C-70 & 1.38 & -6.07 & -62.38 \\
\hline CA_C-71 & 1.51 & -5.54 & -62.85 \\
\hline CA_C-72 & 0.91 & -13.43 & -63.13 \\
\hline CA_C-73 & 0.89 & -13.45 & -63.57 \\
\hline CA_C-74 & 0.95 & -13.49 & -63.66 \\
\hline CA_C-75 & 0.93 & -13.47 & -64.06 \\
\hline
\end{tabular}

Table S2. Carbon and oxygen isotope data for bulk carbonate for the Mójcza section and Core-A. Sample codes in red measured using methods in Sullivan et al. (2018). 

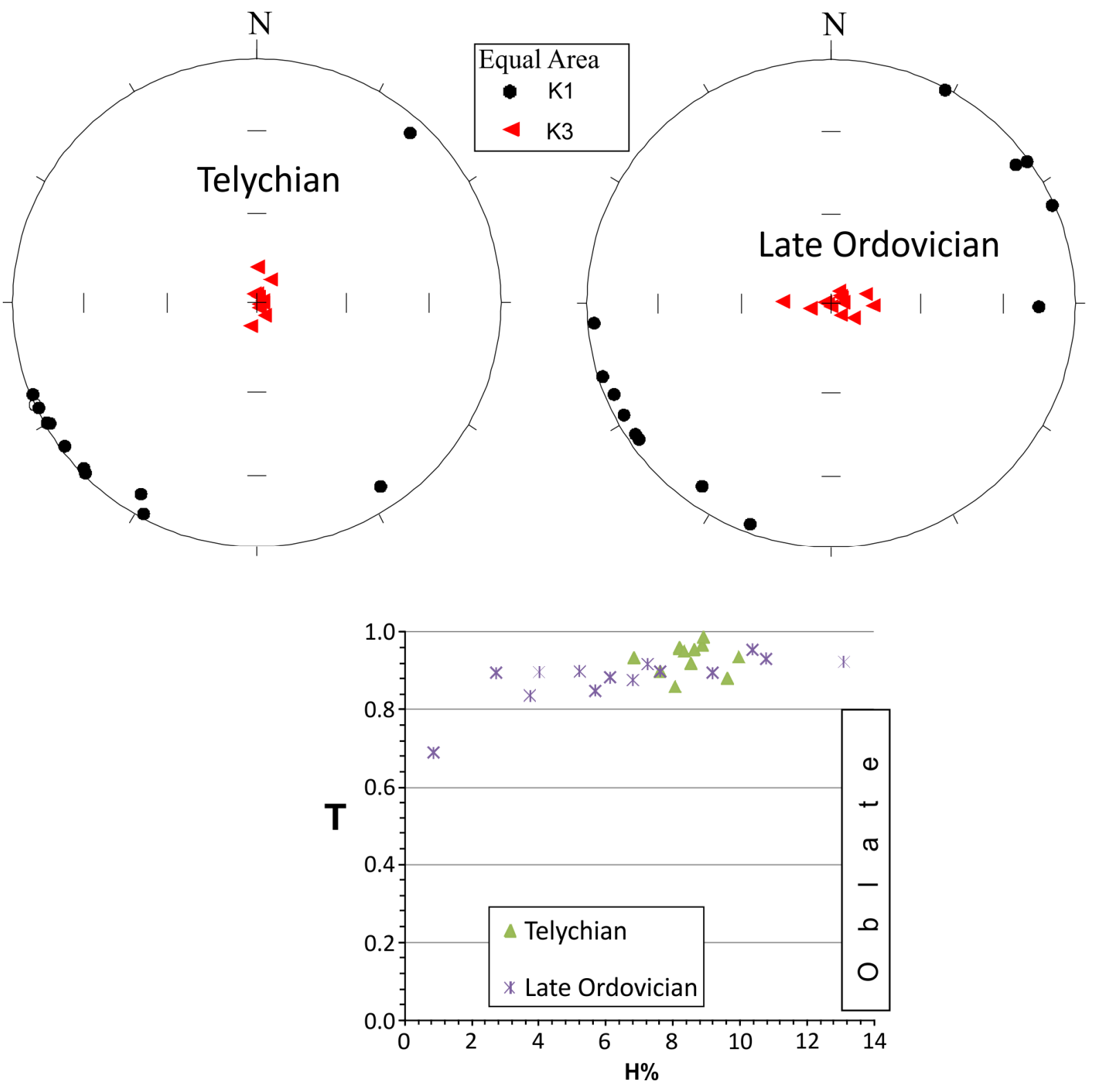

Fig. S5. AMS data for the Grabowiec- 6 core. This also shows the data for the Telychian described by Hounslow et al. (2021). The lower hemisphere AMS maximum $\left(\mathrm{K}_{1}\right)$ and minimum $\left(\mathrm{K}_{3}\right)$ axes are shown in the stereonets and the ellipsoid shape and intensity ( $T$ versus $h \%$ ). Data is oriented using the Kiaman partial remagnetisations. All samples have a sedimentary type fabric, shown by oblate shape $(T>0)$. The mean $K_{1}$ axis is at bearing $067^{\circ}$ and indicates probable distal deposition on a palaeoslope directed to the SW, away from the East European platform coastal zone to the east (Teller, 1997). 

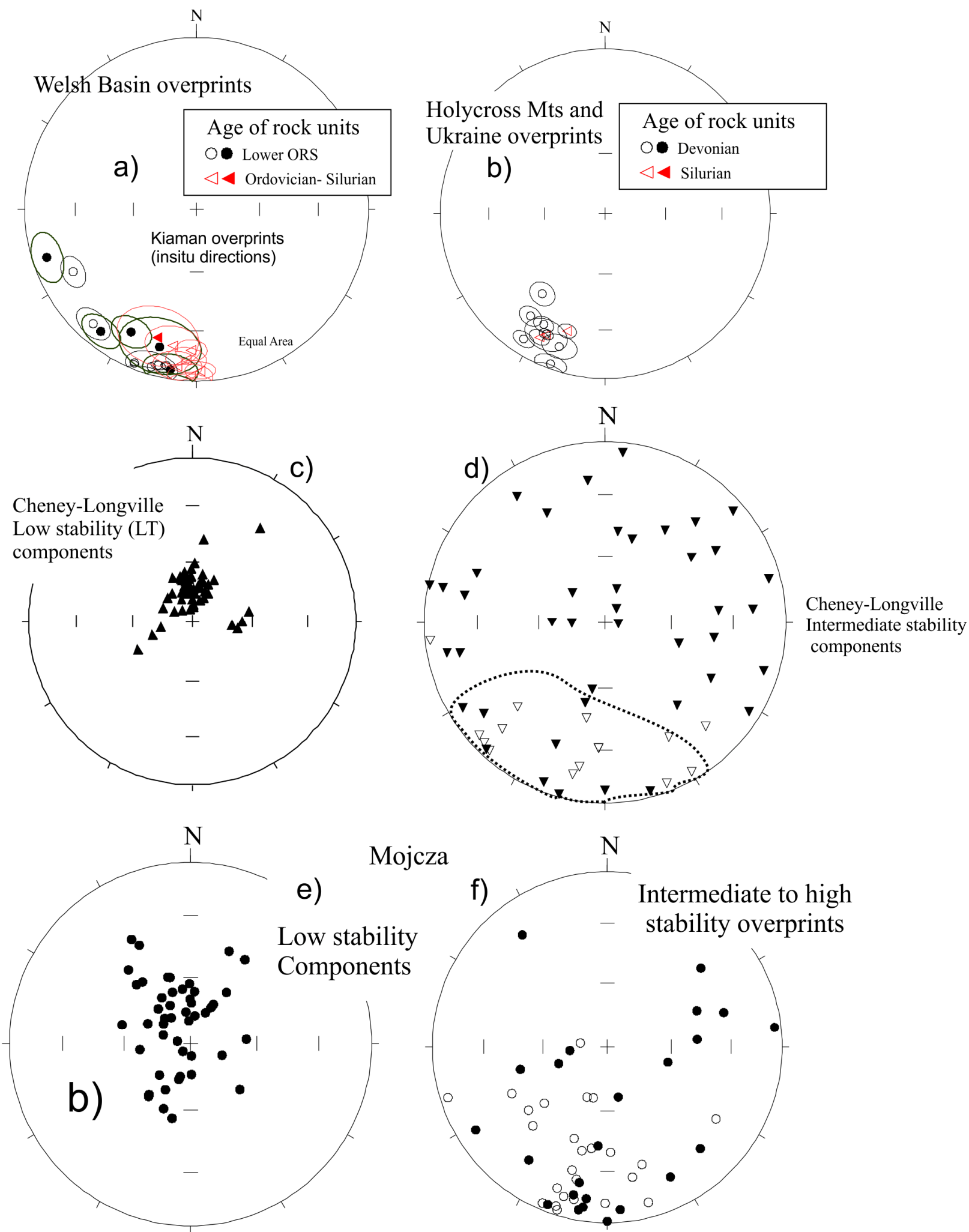

Fig. S6. a), b) Overprint and remagnetisaton directions (igneous and sedimentary rocks) in other published studies from pre-Carboniferous units (Old Red Sandstone, [ORS], Ordovician and Silurian) from: a) the Welsh Basin and b) Poland and Ukraine. Directions are shown with $\alpha_{95}$ confidence cones. Filled symbols lower hemisphere, unfilled upper hemisphere. Equal area projection. Welsh Basin data from: Chamaluan and Creer (1964), McClelland Brown (1983), Smith and Piper (1984), Piper (1995), Setiabudidaya et al. (1994); Stearns and Van der Voo (1987), Channell et al. (1992a,b) and McCabe and Channell (1990), Poland and Ukraine data from: Smethurst and Khramov (1992), Grabowski and Nawrocki (1996, 2001), Zwing, (2003), Jeleńska et al (2005), Szaniawski (2008), Szaniawski \& Lewandowski (2010), Szaniawski et al. (2011). 
c), d), e), f) Low and intermediate stability overprint components from section at: c), d) Cheney Longville and e),f) Mójcza. Low stability components are inferred as Brunhes overprints, with varying degrees of scatter due to unblocking spectra overlap with intermediate stability components. Intermediate stability components at Mójcza are clearly Kiaman-like. The dotted line around the SSW directed intermediate stability components in d), loosely define a Kiaman-like component like seen in other studies, shown in a). Filled symbols lower hemisphere, unfilled upper hemisphere. Equal area projection. All data in insitu coordinates.

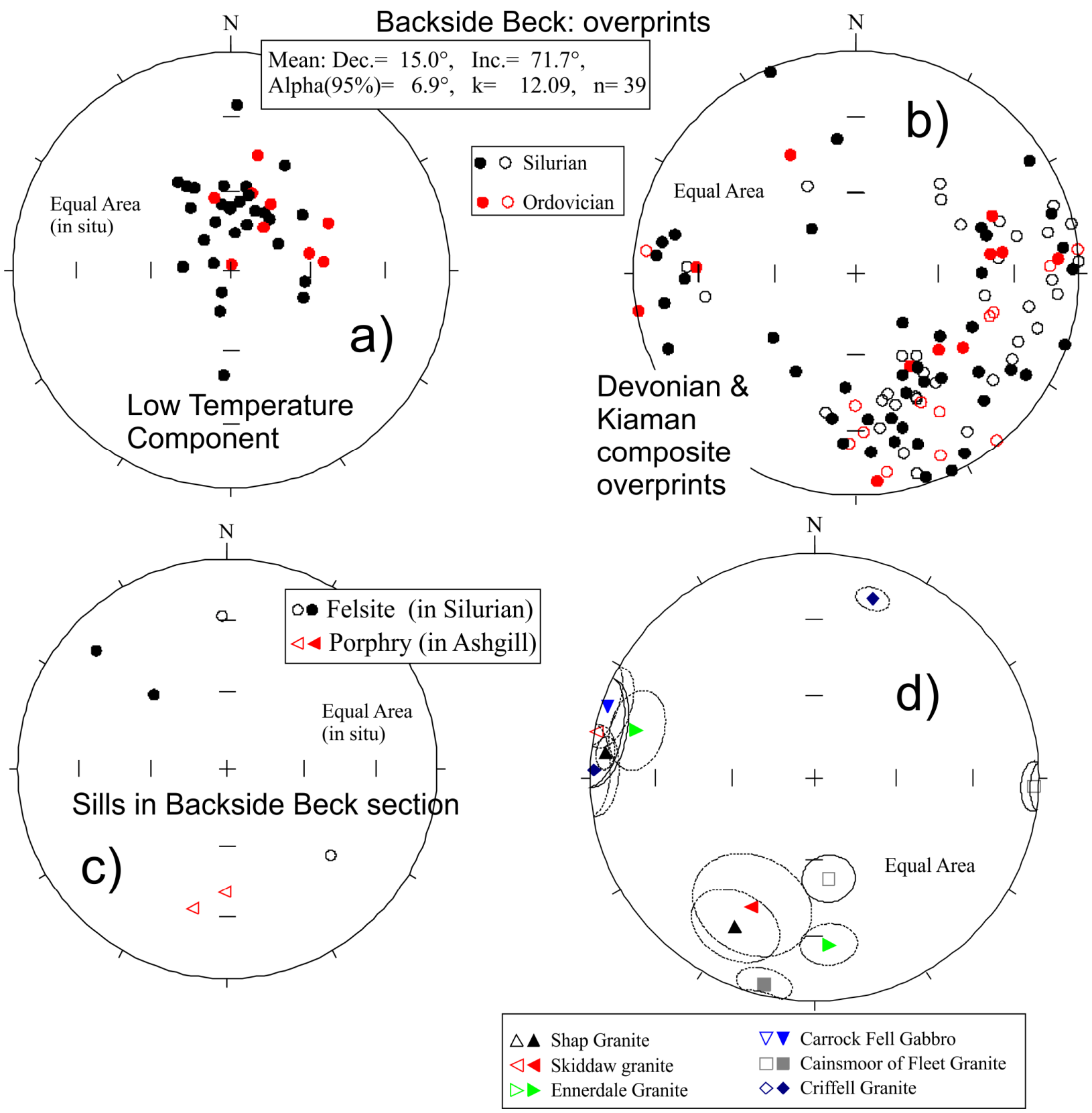

Fig. S7. a), b) Ordovician Backside Beck overprint magnetisation directions from this study. These are shown with the Silurian data (in black in a) and b) from Hounslow et al. (2021). c) Shows the ChRM directions determined from the felsite and porphry sills in the Backside Beck section. d) Post Silurian magnetization directions (and $\alpha_{95}$ confidence cones) for igneous bodies in the Lake District and southern Scotland detailed in Piper (1997). These are both primary Devonian directions (approx. E-W dual polarity group) and later overprints (Kiaman SSW group) identified in the various units detailed in Piper (1997). All data in geographic coordinates. Filled symbols lower hemisphere, unfilled upper hemisphere. 


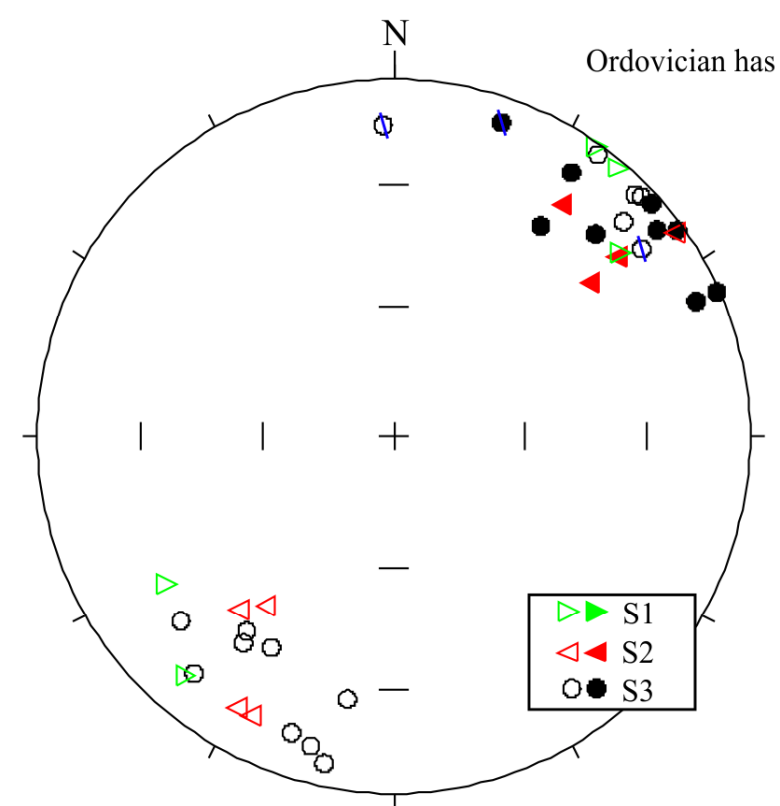

$\cdots$ ChRM Insitu
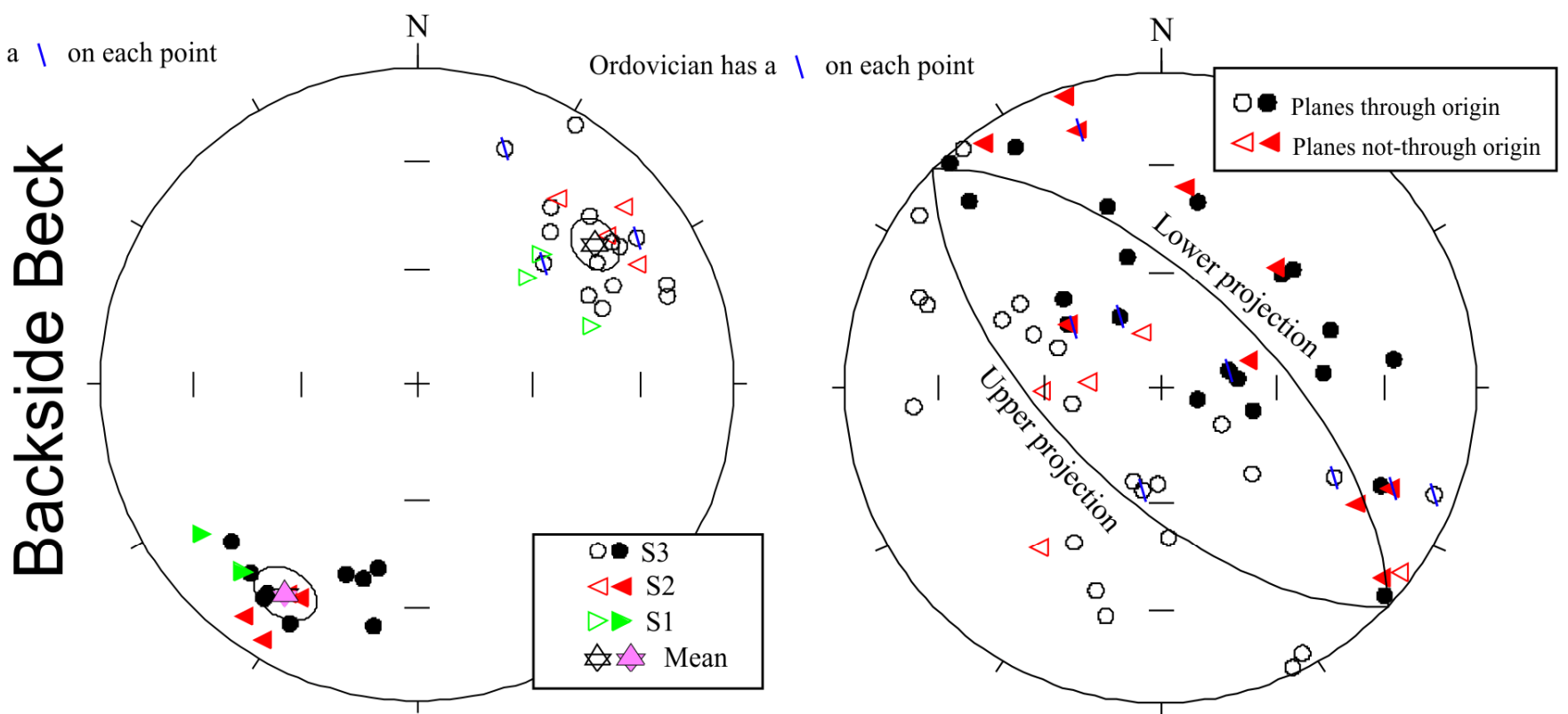

ChRM Stratigraphic
ChRM poles to great

Fig. S8. Characteristic remanence (ChRM) directions for the Backside Beck section. The Ordovician data (blue ticks through symbols) are shown with the Silurian data from Hounslow et al. (2021). Insitu directions shown on the left, bedding corrected in the middle and bedding corrected poles to great circles on the right. The planes through the ChRM great circle poles have a pole which is near the mean of the ChRM line-fit direction in middle panel. The great circle line-fit ChRM plane, which is orthogonal to the S-class mean (derived from S-class data in mid stereonet) is that shown on the right most stereonet. S1 to S3 indicate the demagnetisation behaviour explained in the text. 


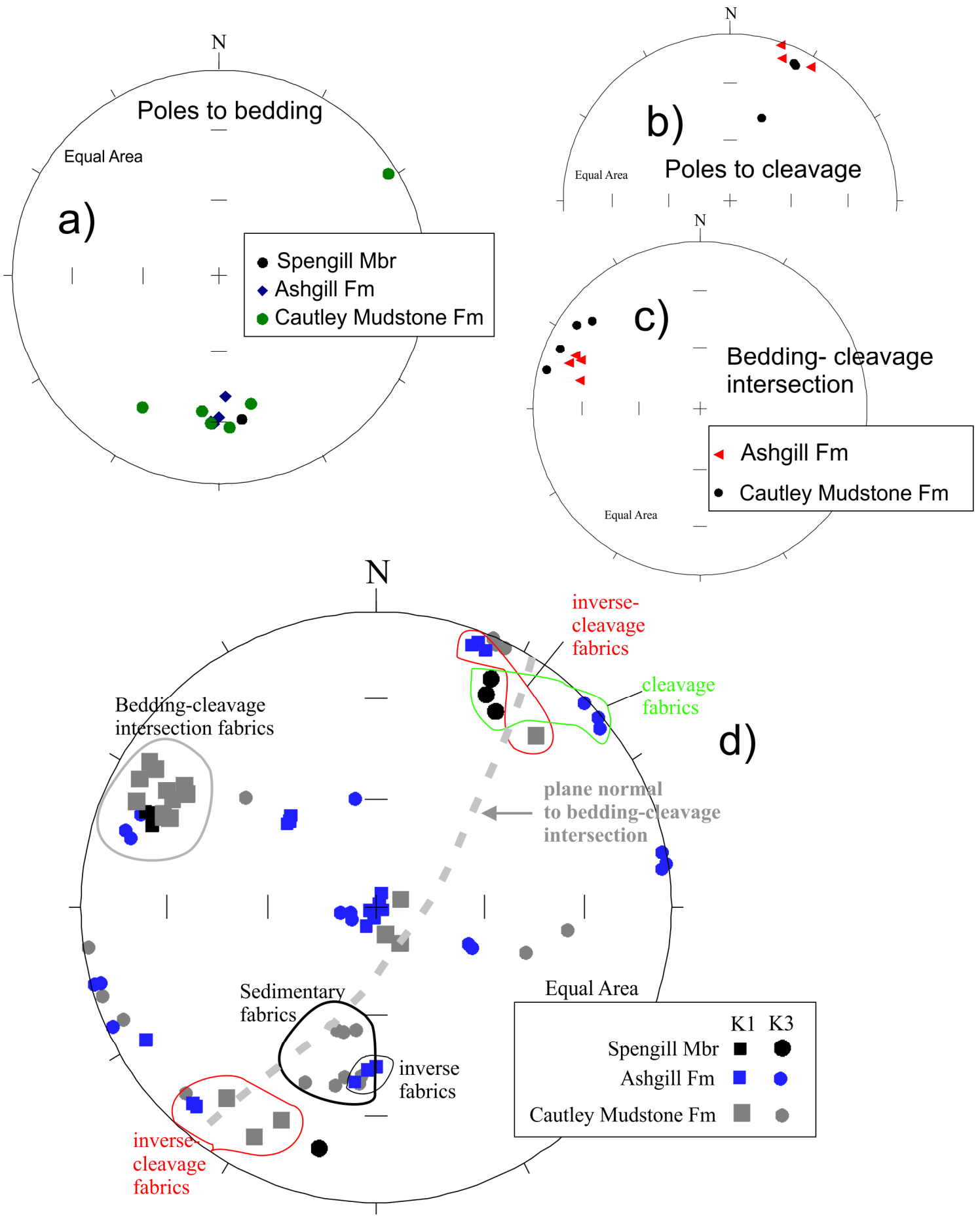

Fig. S9. AMS and structural data for the Ordovician at Backside Beck. a) poles to bedding; b) poles to the incipient cleavage in the section. c) Bedding- cleavage intersection lineations. d) The AMS directional data (in geographic coordinates) with the interpretation overlaid. Some samples from the Cautley Mudstone show primary-like fabrics with $\mathrm{K}_{3}$ near normal to the bedding. A small group from the Ashgill Fm show an inverse-type fabric (Rochette, 1988; Ihmlé et al., 1989; Hounslow, 2001) with $K_{1}$ near normal to the bedding. Most of the sample set show evidence of a tectonic fabric overprint, with $\mathrm{K}_{1}$ close to the beddingcleavage intersection, typical for the initial indictors of strain. Both $K_{1}$ and $K_{3}$ are spread out in a girdle normal to the bedding-cleavage intersection, with some from the Ashgill Fm and Spengill Mbr showing evidence of $\mathrm{K}_{3}$ normal to the cleavage ('cleavage fabrics'), or an inverse fabric to the cleavage ('inverse cleavage fabrics') expressed by the $K_{1}$ axes normal to the cleavage. The inverse fabrics are likely the results of Fe-Mn carbonates in the section (see Hounslow et al., 2021, for more details, and the comparison to the larger set of Silurian data). 


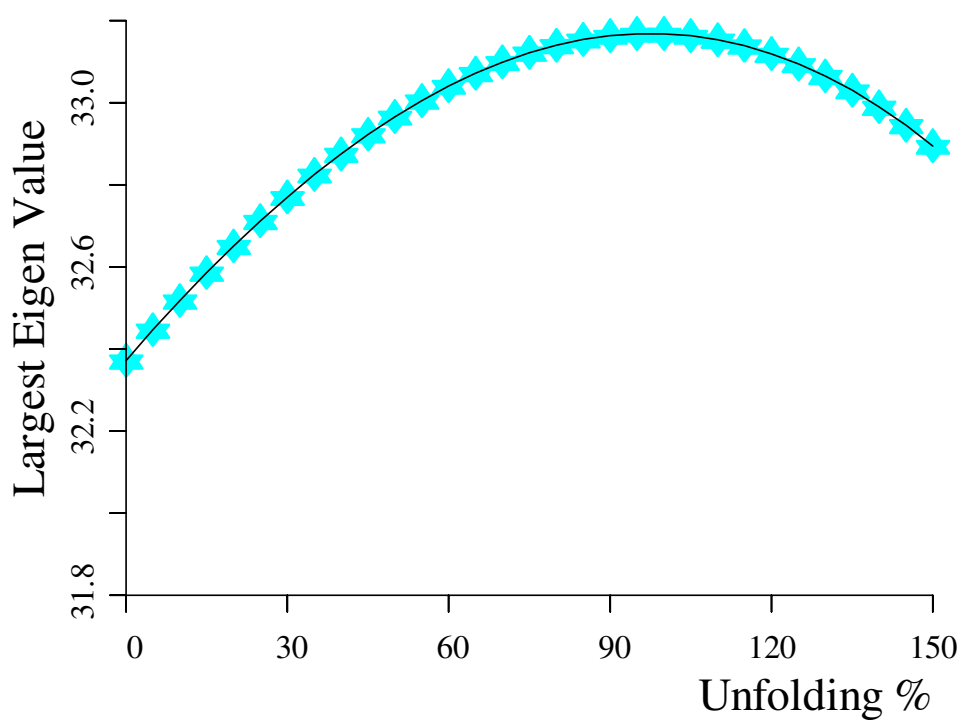

Parametric simulation of confidence Limits 95\% confidence interval

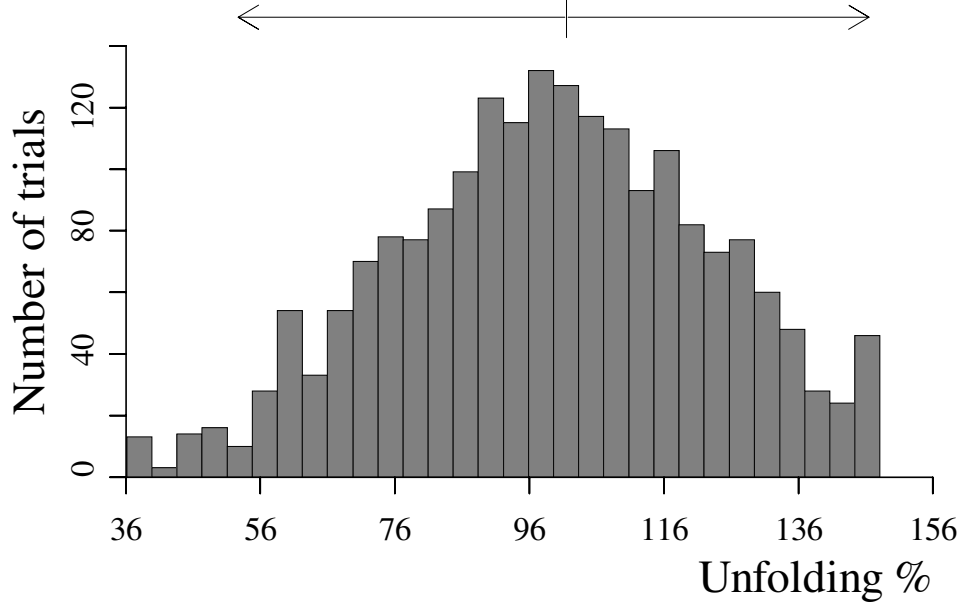

Fig. S10. Backside Beck section fold test data. Upper panel-the progressive unfolding test using the eigen-based test of Tauxe and Watson (1994). Lower panelthe re-sampling (simple) bootstrap simulation of confidence limits, using 2000 simulations. This simulation has median (best) Unfolding $=102.0 \%, 95 \%$ confidence limits on unfolding\% of $53 \%$ and $146 \%$. Ordovician and Silurian data combined (confidence limits can vary by a few\%, since it's a simulation).

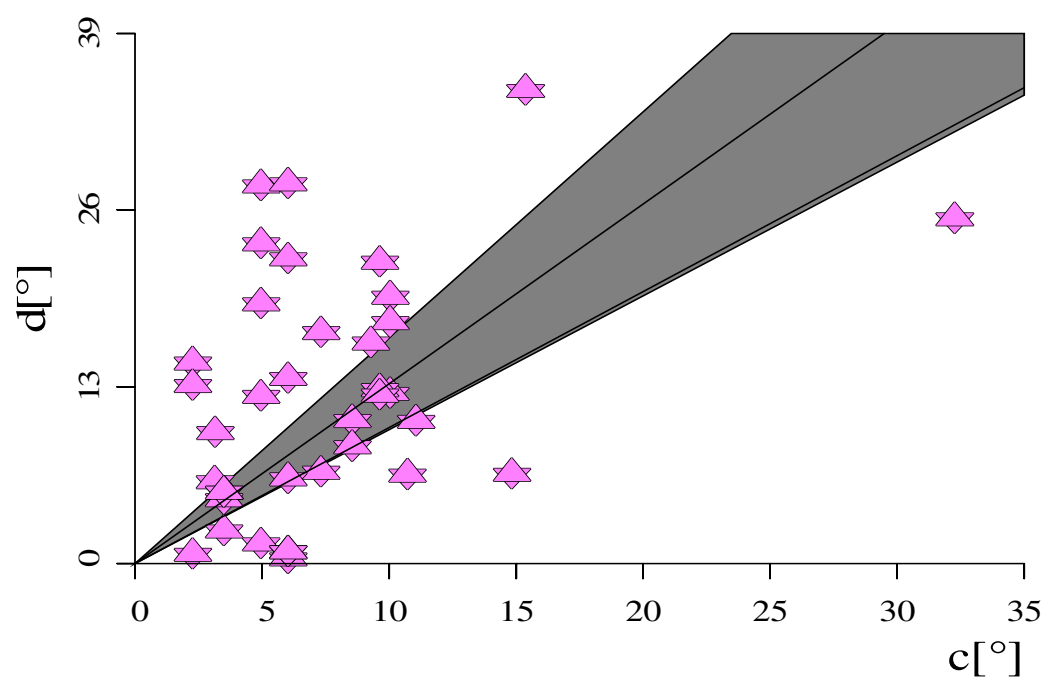

Fig. S11. Backside Beck section showing the DC fold test data of Enkin (2003). Ordovician and Silurian data combined. This is a single sample-test, rather than a site-mean test. Best fitting slope (unfolding) = $132.3 \%$ with $95 \%$ confidence interval: $\pm 33.9 \%$, standard error (sigma) $=16.7$. The DC fold test is positive, indicating the magnetisation was probably acquired PRIOR to folding. See Enkin (2003) for definition of the $d_{i}$ and $c_{i}$ parameters plotted here. 

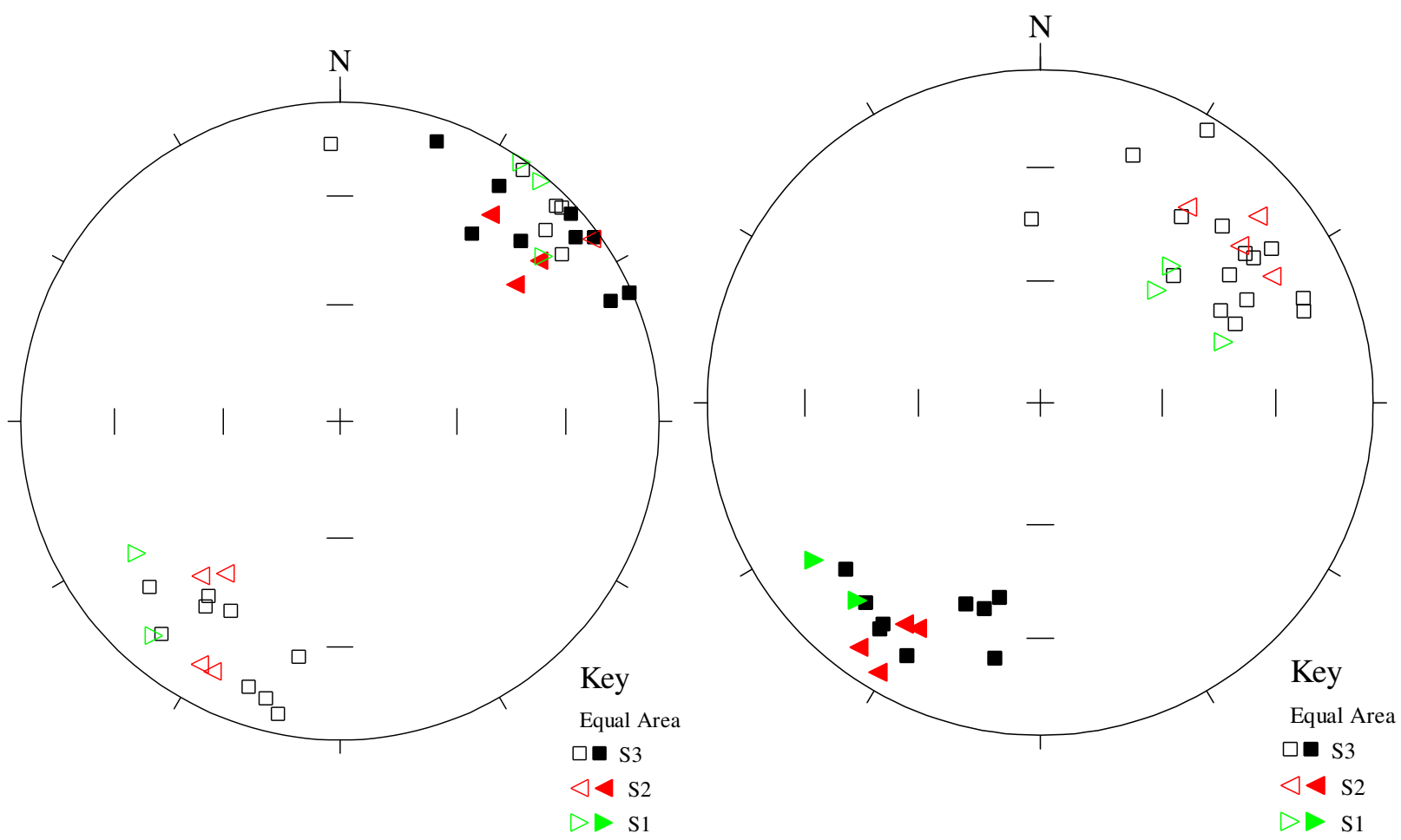

Fig. S12. Backside Beck data used for fold test. Left in geographic, on right in stratigraphic coordinates. geographic coordinate mean $=039.2^{\circ}, 11.5^{\circ}, \alpha_{95}=6.4^{\circ}, k=14.6, n=37$; stratigraphic coordinate mean $222.6^{\circ}, 27.1^{\circ}, \alpha_{95}=5.7^{\circ}, k=17.9, n=37$

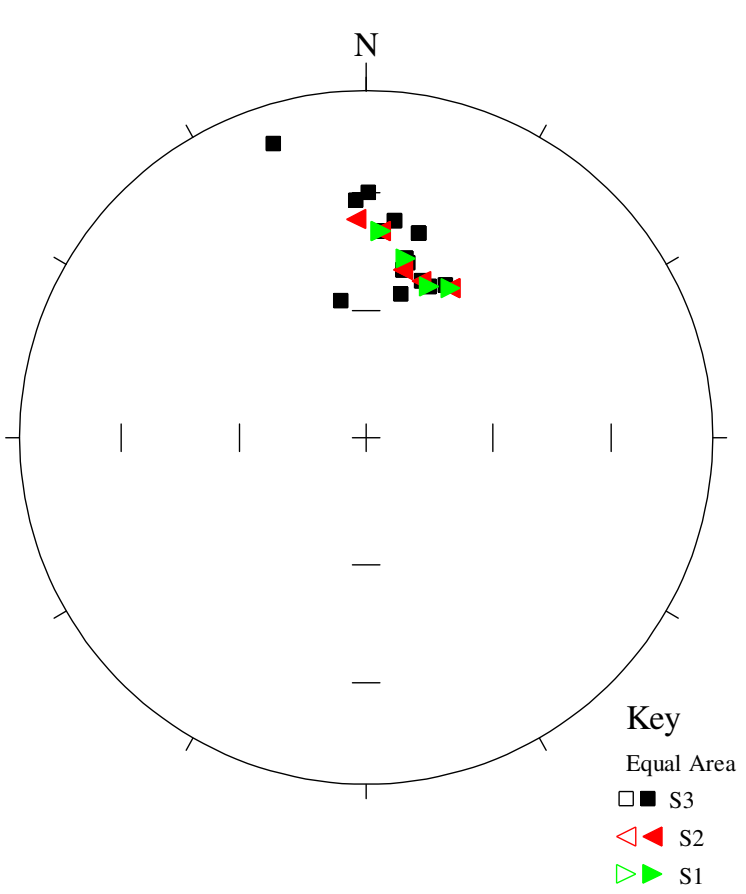

Fig. S13. Bedding dip directions used in the fold test at Backside Beck.

\begin{tabular}{|c|c|c|c|c|c|}
\hline Cluster & $\mathrm{n}$ & $\mathrm{r}$ & $\mathrm{k}$ & Dec. & Inc. \\
\hline \multicolumn{5}{|l|}{ For 0\% unfolding } \\
\hline 1 & 16 & 14.95 & 14.3 & 42.4 & 2.7 \\
\hline 2 & 21 & 19.93 & 18.7 & 36.7 & 18.1 \\
\hline \multicolumn{5}{|l|}{ For $100 \%$ unfolding } \\
\hline 1 & 16 & 15.05 & 15.8 & 47.4 & -25.8 \\
\hline 2 & 21 & 20.02 & 20.4 & 38.9 & -28.1 \\
\hline
\end{tabular}

Table S3. The data used for the McFadden (1998) fold test with the statistics for the two data clusters used at 0 and 100 percent unfolding.

\section{Explanation of component fitting procedures using Linefind.}

LINEFIND is explained in detail in Kent et al. (1983) and in outline in McFadden \& Schmidt (1986), and has a number of features which make it substantially different in use to 'standard' manual-PCA fitting as widely used in much software. Heslop \& Roberts (2016) have also recently re-examined some of the fundamental problems with standard PCA fits. One of the conundrums as they put it is: "It is not apparent why the 
methods of Schmidt [1982], Kent et al. [1983], and McFadden and Schmidt [1986] have not been employed more widely by the paleomagnetic community". Presumably this is partly an issue of availability of suitable software. Linefind is a superior analysis tool (and extension to) to the standard manual PCA method of fitting lines and planes, since it uses the uncertainty in the measurement, plus additional error propagation, plus statistical tests for lines and planes. As Kent et al. (1983) aptly summarized "components oblique to the chosen axes of projection are non-ideally presented [on Zijderveld plots], accuracy of best-fit lines estimated on two-dimensional plots is dependent on the choice of projection planes; assignment of data points to a model line is arbitrary [in standard PCA] and small components can still be overlooked unless highlighted on magnified inset diagrams. The methods in this paper are free from all those shortcomings".

Fundamentally LINEFIND takes away the choice of which points to fit lines and planes to, and substitutes a choice of a proxy- estimate of the combined uncertainties in the data (this proxy is called rho). The practical differences to standard PCA are:

1) It requires a measurement uncertainty (or variance), usually derived from multiple magnetometer measurements of each X,Y,Z component. For the Lancaster GM400 magnetometer, this would normally be 12 measurements per axis, combined into 6 unbiased sets (to remove inhomogeneity). For JR6 data this is derived from the dispersion value. For the Lancaster RAPID 2 G (1 specimen position) this would be 4 measurements of each axis, combined into 2 unbiased pairs (on X, Y) and a biased set of 4 on $Z$.

2) LINEFIND uses the $X, Y, Z$ variance data (see Briden \& Arthur, 1981 for formulation) either as they are, or fits a smoothed variance model to the data (i.e. one of the two choices for a 'noise model'). With the smoothed noise model it may also derive an estimate of the variance for the origin (or treat its variance as zero). To use LINEFIND, the user must first decide to either use the 'noise model', or use the sample variance. Most specimen datasets use the noise model, but if the model is a poor fit to the data (it has a statistical test for this- goodness-of-fit, and displays residuals- 'Log-Crit-Value'; Fig. S14), then the measured variance can be used (origin has zero variance in this specimen-variance model). Generally the statistical test for a suitable model fit is rather overoptimistic, and its better sometimes to use the specimen variance when there is much greater than usual variation between steps (Goodness-of-fit is too large). This is decided by looking at the data and log-residuals (right of Fig. S14).

Fig. S14. Example screen for the noise model fit. In this example, the $4^{\text {th }}$ step has a large residual, indicating the sample variance should probably be chosen (also a large Goodness-of-Fit statistic) and not the fitted error model (Or the $4^{\text {th }}$ point could be deleted). This 'fitted' model also rather over-estimates the variance in the last half of the steps.
The fitted error model is 0.K.

GLIM Regression coeef icients are $0.00000 \quad 0.18703 \mathrm{E}-02$

Goodness - of $-\mathrm{f}$ it statistic $=243.38$ with 14 D.F.

206_1 01972.39m F-plug

Number of data points : 17, Number of replications :

$\begin{array}{llll}X 1 & \times 2 & \text { Fitted Sample }\end{array}$

$-0.35496$

$-0.35434$

$-0.35947$

$-0.35679$

$-0.34034$

$-0.32472$

$-0.30481$

$-0.30131$

$-0.28211$

$-0.27345$

$-0.25943$

$-0.24436$

$-0.22903$

$-0.22794$

$-0.22775$

$-0.22898$

0.00000

$\begin{array}{ll}-0.10776 & -0.96954 \\ -0.93773 \mathrm{E}-01 & -0.62387 \\ -0.10052 & -0.38305 \\ -0.11529 & -0.26156 \\ -0.92667 \mathrm{E}-01 & -0.12951 \\ -0.85224 \mathrm{E}-01 & -0.71005 \mathrm{E}-01 \\ -0.95248 \mathrm{E}-01 & -0.53985 \mathrm{E}-01 \\ -0.10903 & -0.29005 \mathrm{E}-01 \\ -0.15370 & 0.42353 \mathrm{E}-01 \\ -0.17554 & 0.81293 \mathrm{E}-01 \\ -0.20436 & 0.11975 \\ -0.24201 & 0.18302 \\ -0.27699 & 0.22552 \\ -0.29004 & 0.22203 \\ -0.30801 & 0.24545 \\ -0.26106 & 0.26315 \\ 0.00000 & 0.00000\end{array}$

Uar

$0.53499 \mathrm{E}-03 \quad 0.31524 \mathrm{E}-03$

$0.39090 \mathrm{E}-03 \quad 0.38060 \mathrm{E}-02$

$0.26406 \mathrm{E}-03 \quad 0.15808 \mathrm{E}-03$

$0.22022 \mathrm{E}-03 \quad 0.15922 \mathrm{E}-03$

$0.19619 \mathrm{E}-03 \quad 0.13458 \mathrm{E}-04$

$0.19360 \mathrm{E}-03 \quad 0.13436 \mathrm{E}-04$

$0.19638 \mathrm{E}-03 \quad 0.57792 \mathrm{E}-04$

$0.20985 \mathrm{E}-03 \quad 0.31785 \mathrm{E}-04$

$0.23080 \mathrm{E}-03 \quad 0.29941 \mathrm{E}-04$

$0.28387 \mathrm{E}-03 \quad 0.12567 \mathrm{E}-03$

$0.33673 \mathrm{E}-03 \quad 0.10070 \mathrm{E}-03$

$\odot .34671 \mathrm{E}-03 \quad 0.76755 \mathrm{E}-04$

$0.38712 \mathrm{E}-03 \quad 0.11505 \mathrm{E}-03$

$\Theta .35504 \mathrm{E}-03 \quad 0.47538 \mathrm{E}-04$

0.00000
Resid. Log Crit. Ualue 2.302

0.320

0.121

52.576

0.129

0.270

0.000

0.000

0.004

0.000

0.000

0.034

0.004

0.001

0.004

0.000

0.000 
3) These variance estimates (one of the two 'noise' models) to use are added to by an 'excess noise' proxy using the parameter rho (the so called 'excess standard deviation'). That is when rho=1 the total variance is like in the error model chosen. The additional 'excess-noise ' comes from things like between-step orientation errors, short-term viscous remanence, GRM, thermal alteration, magnetometer/ambient noise, changes in holder magnetisation. Generally a rho between $\sim 1$ to $\sim 5$ is required to give sensible looking fits to the data (but sometimes outside this range). The choice of what rho to use is the major fundamental choice the user needs to make.

$\begin{array}{llll}\text { RHO }=0.20 \text { Partial AIC }=0.12458 & \mathrm{NDF}=12 & \mathrm{MDF}=36 \\ \text { RHO }=0.40 \text { Partial AIC }=3.2475 & \mathrm{NDF}=22 & \mathrm{MDF}=26 \\ \text { RHO }=0.60 \text { Partial AIC }=3.2475 & \mathrm{NDF}=22 & \mathrm{MDF}=26 \\ \text { RHO }=0.80 \text { Partial AIC }=3.2984 & \mathrm{NDF}=22 & \mathrm{MDF}=26 \\ \text { RHO }=1.00 \text { Partial AIC }=3.7467 & \mathrm{NDF}=26 & \mathrm{MDF}=22 \\ \text { RHO }=1.20 \text { Partial AIC }=5.5767 & \mathrm{NDF}=26 & \mathrm{MDF}=22 \\ \text { RHO }=1.40 \text { Partial AIC }=5.5767 & \mathrm{NDF}=26 & \mathrm{MDF}=22 \\ \text { RHO }=1.70 \text { Partial AIC }=5.5625 & \mathrm{NDF}=26 & \mathrm{MDF}=22 \\ \text { RHO }=2.00 \text { Partial AIC }=5.5625 & \mathrm{NDF}=26 & \mathrm{MDF}=22 \\ \text { RHO }=2.50 \text { Partial AIC }=5.5625 & \mathrm{NDF}=26 & \mathrm{MDF}=22 \\ \text { RHO }=3.00 \text { Partial AIC }=5.5625 & \mathrm{NDF}=26 & \mathrm{MDF}=22 \\ \text { RHO }=4.00 \text { Partial AIC }=4.8158 & \mathrm{NDF}=24 & \mathrm{MDF}=18 \\ \text { RHO }=5.00 \text { Partial AIC }=4.8158 & \mathrm{NDF}=24 & \mathrm{MDF}=18 \\ \text { RHO }=7.00 \text { Partial AIC }=5.4435 & \mathrm{NDF}=28 & \mathrm{MDF}=20 \\ \text { RHO }=10.00 \text { Partial AIC }=5.4435 & \mathrm{NDF}=28 & \mathrm{MDF}=20 \\ \text { Best model } \text { RHO }=0.40000 & \mathrm{AICP}= & 3.2475 & \end{array}$

4) Selecting a rho 1 will often over specify the number of linear segments in the data, and massively overestimating rho will give only one linear segment (or none). The selection of the best rho is guided by two things. Firstly the Akaikes Information criteria (AIC, actually the partial AIC; Kent et al., 1983), which should plateau (or ideally drop slightly from the previous rho-step) to give the best rho-modelestimate. E.g. in Fig. $\mathrm{S} 15$ example, there is rho=4 (pAIC=4.8158) which is lower than the previous step at 5.5625. However, there may be several such steps-changes in pAIC, and several choices may be possible (e.g. 0.4 to $0.6 ; 1.7$ to 3.0 in Fig. S15). Secondly, and obviously most importantly, rho needs to be selected based on LINEFINDS interpretation of the Zijderveld and steronet-plots of the demagnetisation data, to guide which parts of the data may have suitable linear segments. In this case pAIC selection worked ok (i.e rho=4, but actually closer to 3.5 ), giving 3 components and a GC plane (Fig. S16). Component A is a possible Brunhes (but rather steep, so may be ?drilling-induced- this is an example from Core-A). The $\mathrm{C}$ component is the inferred ChRM, in this case through the origin (the origin step is 999). The B component is inferred as a composite intermediate component and is largely seen during AF demagnetisation (the 'Range' in Fig. S16 is a composite Temp-AF scale). The fitted plane in this case is one, which includes the entire dataset, implying there is some unblocking-spectra overlap of all these 3 'linear' components. 


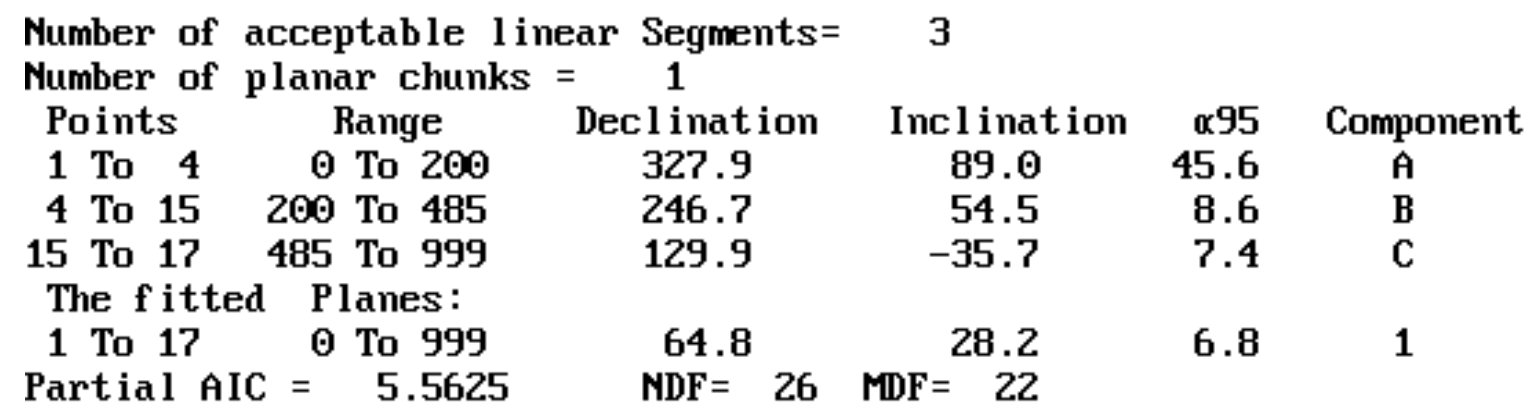

Fig. S16. Sample data which is thermally demagnetised to $350^{\circ} \mathrm{C}$ then AF demagnetised to $100 \mathrm{mT}$. Linear and planar segments with a rho $=4$. A second parameter 'radtol' can be set which filters out (does not display) linear segments which exceed a $\alpha 95$ threshold (default is $20^{\circ}$, but $40^{\circ}$ has been typically used). The above example uses radtol $=50^{\circ}$. Assuming 3 points on a line -fit not anchored to the origin, a radtol of $40^{\circ}$ and $50^{\circ}$ would equate to MAD values of $6.7^{\circ}$ and $8.3^{\circ}$ respectively (Khoklov \& Hulot, 2016).

5) The automatic choice of linear segments can be overridden by introducing 'break points', in case the lines 'overspill'- which can happen for strong linear segments. In this respect this manual break point is similar to conventional PCA, pinning the ends of the linear segments. Unlike conventional PCA, linear segments cannot be anchored to the origin. LINEFIND decides if a line in sufficiently co-linear with the origin. A larger rho will allow co-linear-with-origin behaviour to be more likely. Sometimes a breakpoint may be needed at the HT end of a long LT line segment, so it does not overspill into the weaker HT components. It may also be needed at the LT and MT join if the MT or LT component is long and strong.

6) Key strengths of LINEFIND are: $A$ ) its ability to use the measurement errors, and a noise model of the data, B) its automatic, and objective statistical selection of linear and planar segments, stemming from the uncertainties and given guidance from interpretation of the data thorough choice of rho. C) It can find small components, or components which may be unseen in the particular 2D Zijderveld projection being used- i.e. if its near-orthogonal to the page (i.e. its not dependent on chosen projection). D) Linear segments can be overridden, based on interpretation of the data with break points. E) It may give a selection of statistically significant GC planes to the data (hinting at component overlap), rooted in the measurement variance and the rho chosen.

Therefore, when combined with conventional interpretation of data using demagnetisation diagrams, the use of LINEFIND is a more objective method of analysis than conventional 'eye-balled' PCA fits. A DosBox version of Linefind (linef.exe), and its source code can be found at the following DOI:

10.13140/RG.2.2.29761.38244, or the link:

https://www.researchgate.net/publication/347327549 A DOSBox version of Linefind.

DosBox is a Dos emulator which runs on many platforms, and can be obtained from:

https://www.dosbox.com/information.php?page $=0$.

The format of files needed by Linef.exe can be created with the windows software, GM4Edit available from the DOI of Hounslow (2019), which contains additional help on these file formats.

\section{Statistics of the demagnetisation data analysis}

The statistics from the LINFIND fitting procedure applied to all the data are detailed in Table S3. Broadly these indicate the following: A) The Möjcza data has the largest set of rho values, which probably relates to the fact that this was measured on the JR6 (1 unbiased per axis; Briden \& Arthur; 1981), whereas others were largely measured on the GM400, 3-axis squid system (6 unbiased per axis), B) Data from the Cheney 
Longville section has the next largest rho, which may be rather noiser data, since this section contained a lot of sandier lithologies, which may not be such good field recorders as the finer-grained lithologies in the other sections. C) Average $\alpha_{95}$ is approximately related to the S1 to S3 classes, but this relationship varies, because of its dependency on rho and the measurement variance. D) Average $\alpha_{95}$ is not systematically related to the T1 to T3 classes, likely because the quality category is also dependent on the length of approach to the ChRM direction. Comparing confidence intervals between lines and planes (i.e. pole for the great circle plane) is unwise, since the planes generally contain more measurement points.

\begin{tabular}{|c|c|c|c|c|c|}
\hline Section/Core & Class & $\mathrm{N}$ & rho & $\alpha_{95}\left({ }^{\circ}\right)$ & $\begin{array}{l}\text { equivalent } \\
\operatorname{MAD}^{1}\left({ }^{\circ}\right)\end{array}$ \\
\hline Backside Beck [BB] & S1 & & & & \\
\hline \multirow[t]{5}{*}{ (Ordovician) } & S2 & & & & \\
\hline & S3 & 3 & 3 & 30.5 & 5.1 \\
\hline & T1 & 4 & 1.5 & 15.3 & 2.6 \\
\hline & $\mathrm{T} 2$ & 2 & 2.2 & 25.1 & 4.2 \\
\hline & T3 & 2 & 1.7 & 8 & 1.3 \\
\hline Cheney & S1 & & & & \\
\hline \multirow[t]{5}{*}{ Longville [CL] } & S2 & 5 & 4 & 14.5 & 2.4 \\
\hline & S3 & 28 & 5 & 18.8 & 3.1 \\
\hline & $\mathrm{T} 1$ & 9 & 4.5 & 15.7 & 2.6 \\
\hline & $\mathrm{T} 2$ & 4 & 5 & 14.8 & 2.5 \\
\hline & T3 & 8 & 2.8 & 23.4 & 3.9 \\
\hline \multirow[t]{6}{*}{ Möjcza [M] } & S1 & 2 & 4 & 6.3 & 1.1 \\
\hline & S2 & 2 & 7 & 12.7 & 2.1 \\
\hline & S3 & 8 & 4 & 22.9 & 3.8 \\
\hline & $\mathrm{T} 1$ & 6 & 4 & 12 & 2.0 \\
\hline & $\mathrm{T} 2$ & 4 & 1.4 & 21.9 & 3.7 \\
\hline & T3 & 13 & 3 & 17.9 & 3.0 \\
\hline \multirow[t]{6}{*}{ Grabowiec-6 } & S1 & 1 & 7 & 27 & 4.5 \\
\hline & S2 & & & & \\
\hline & S3 & 5 & 1.7 & 15.3 & 2.6 \\
\hline & $\mathrm{T} 1$ & 3 & 1.9 & 14.8 & 2.5 \\
\hline & $\mathrm{T} 2$ & 5 & 1.9 & 14.8 & 2.5 \\
\hline & T3 & 6 & 1.3 & 15.7 & 2.6 \\
\hline \multirow[t]{6}{*}{ Core-A } & S1 & 23 & 1 & 5.6 & 0.9 \\
\hline & S2 & 40 & 1.4 & 12.1 & 2.0 \\
\hline & S3 & 44 & 1.4 & 13.3 & 2.2 \\
\hline & $\mathrm{T} 1$ & 3 & 1.75 & 13.1 & 2.2 \\
\hline & $\mathrm{T} 2$ & 2 & 1.4 & 14.1 & 2.4 \\
\hline & T3 & 1 & 2.5 & 14 & 2.3 \\
\hline
\end{tabular}

Table S3. Statistics from the LINFIND fitting procedures applied to the demagnetisation classes. $\mathrm{N}=$ number in each category. Rho=median excess standard deviation, and $\alpha_{95}$ is geometric mean of the $95 \%$ confidence interval as determined by LINEFIND. For T-class data this uncertainty is on the pole to the great circle. ${ }^{1}$ equivalent maximum angular deviation (MAD) uses Khoklov \& Hulot (2016) with 3 points anchored- i.e. their $C_{a M A D}(3)$ conversion of 6.0. For the better defined lines and planes with more data points MAD will be an underestimate. 


\section{Supplementary References}

Briden, J.C., Arthur, G.R., 1981. Precision of measurement of remanent magnetization. Canadian Journal of Earth Sciences, 18, 527-538.

Chamalaun F. H., Creer K. M., 1964. Thermal demagnetization studies on the Old Red Sandstone of the Anglo-Welsh cuvette. Journal of Geophysical Research 69, 1607-1616.

Channell, J. E. T., McCabe, C., Woodcock, N. H. 1992a. Early Devonian (pre-Acadian) magnetization directions in Lower Old Red Sandstone of south Wales (UK). Geophysical Journal International 108, 883-894.

Channell, J. E. T., McCabe, C., Torsvik, T. H., Trench, A., Woodcock, N. H., 1992b. Palaeozoic palaeomagnetic studies, in the Welsh Basin-recent advances. Geological Magazine 129, 533-542.

Enkin, R.J., 2003. The direction-correction tilt test: an all-purpose tilt/fold test for paleomagnetic studies. Earth and Planetary Science Letters 212, 151-166.

Grabowski, J., Nawrocki, J., 1996. Multiple remagnetizations in the Devonian carbonates in the northwestern part of the Kielce region (Holy Cross Mts., southern part).Geological Quarterly 40, 47-64.

Grabowski, J., Nawrocki, J., 2001. Palaeomagnetism of some Devonian carbonates from the Holy Cross Mts. (central Poland): large pre-Permian rotations or strain modified palaeomagnetic directions? Geological Quarterly 45, 165-178.

Heslop, D., Roberts, A.P., 2016. Estimation and propagation of uncertainties associated with paleomagnetic directions. Journal of Geophysical Research: Solid Earth 121, 2274-2289.

Hounslow, M. W., 2001. The crystallographic fabric and texture of siderite in concretions: implications for siderite nucleation and growth processes. Sedimentology 48, 533-557.

Hounslow, M.W. 2019. GM4Edit (v.5.6) -a windows program to manage, plot, export and manipulate paleomagnetic magnetometer datasets DOI: 10.13140/RG.2.2.31877.91361/1.

Hounslow, M.W., Harris, S., Wójcik, K. Nawrocki, J., Woodcock, N.H., Ratcliffe, K.T, Montgomery, P. 2021. Geomagnetic polarity during the Early Silurian: the first magnetostratigraphy of the Llandovery. Palaeogeog. Palaeoecol. Palaeoclimat. In press.

Ihmlé, P. F., Hirt, A. M., Lowrie, W., Dietrich, D., 1989. Inverse magnetic fabric in deformed limestones of the Morcles nappe, Switzerland. Geophysical Research Letters 16, 1383-1386.

Jeleńska, M., Bakhmutov, V., Konstantinienko, L., 2005. Paleomagnetic and rock magnetic data from the Silurian succession of the Dniester basin, Ukraine. Physics of the Earth and Planetary Interiors 149, 307-320.

Kent, J.T., Briden, J.C., Mardia, K.V., 1983. Linear and planar structure in ordered multivariate data as applied to progressive demagnetization of palaeomagnetic remanence. Geophysical Journal International, 75, 593-621.

Khokhlov, A., Hulot, G. 2016. Principal component analysis of palaeomagnetic directions: converting a Maximum Angular Deviation (MAD) into a $\alpha_{95}$ angle. Geophys. J. Int. 204, 274-291. 
Kowalczewski, Z., 1990. Grubookruchowe skały kambru na s'rodkowym południu Polski (litostratygrafia, tektonika, paleogeografia). Prace Pan'stwowego Instytutu Geologicznego 131, 82 pp

McCabe, C., Channell, J. E.T., 1990. Paleomagnetic results from volcanic rocks of the Shelve Inlier, Wales: evidence for a wide Late Ordovician lapetus Ocean in Britain. Earth and Planetary Science Letters $96,458-468$.

McClelland-Brown, E., 1983 Palaeomagnetic studies of fold development and propagation in the Pembrokeshire Old Red Sandstone. Tectonophysics 98, 131-149.

McFadden, P.L. , Schmidt, P.W., 1986. The accumulation of palaeomagnetic results from multicomponent analyses. Geophysical Journal International 86, 965-979.

Peters, C., Dekkers, M. J., 2003. Selected room temperature magnetic parameters as a function of mineralogy, concentration and grain size. Physics and Chemistry of the Earth, Parts A/B/C 28 659667.

Peters, C., Thompson, R. 1998. Magnetic identification of selected natural iron oxides and sulphides. Journal of Magnetism and Magnetic Materials 183, 365-374

Piper, J. D. A., 1995. Palaeomagnetism of Late Ordovician igneous intrusions from the northern Welsh Borderlands: implications to motion of Eastern Avalonia and regional rotations. Geological Magazine 132, 65-80.

Piper, J. D. A., 1997. Palaeomagnetism of igneous rocks of the Lake District (Caledonian) terrane, northern England: Palaeozoic motions and deformation at a leading edge of Avalonia. Geological Journal 32, 211-246.

Rickards, R. B. 1970. The Llandovery (Silurian) graptolites of the Howgill Fells, northern England. Monograph of the Palaeontographical Society, London, 1-108.

Rickards R.B. 1989. Northern England. In: Holland, C. H., Bassett, M. G. A Global Standard for the Silurian System. National Museum of Wales Geological Series 9, 267-274.

Rochette, P., 1988. Inverse magnetic fabric in carbonate-bearing rocks. Earth and Planetary Science Letters 90, 229-237.

Rühle, E., Ciuk, E., Osika, R., Znosko, J., 1977. Geological Map of Poland without Quaternary deposits, scale 1: 500 000. Wydawnictwa Geologiczne.

Setiabudidaya, D., Piper, J. D. A., Shaw, J., 1994. Palaeomagnetism of the (Early Devonian) Lower Old Red Sandstones of South Wales: implications to Variscan overprinting and differential regional rotations. Tectonophysics 231, 257-280.

Smethurst, M.A., Khramov, A.N., 1992. A new Devonian palaeomagnetic pole for the Russian platform and Baltica, and related apparent polar wander. Geophys. J. Int. 108, 179-192.

Smith, R. L., Piper, J. D. A., 1984. Palaeomagnetic study of the (Lower Cambrian) Longmyndian sediments and tuffs, Welsh Borderlands. Geophysical Journal International 79, 875-892.

Stearns, C., Van Der Voo, R., 1987. Paleomagnetic results from the Lower Devonian Llandstadwell Formation, Dyfed, Wales. Tectonophysics 143, 329-334. 
Sullivan, N. B., Loydell, D. K., Montgomery, P., Molyneux, S. G., Zalasiewicz, J., Ratcliffe, K. T., Lewis, G., 2018. A record of Late Ordovician to Silurian oceanographic events on the margin of Baltica based on new carbon isotope data, elemental geochemistry, and biostratigraphy from two boreholes in central Poland. Palaeogeography, Palaeoclimatology, Palaeoecology 490, 95-106.

Szaniawski, R., 2008. Late Paleozoic geodynamics of the Małopolska Massif in the light of new paleomagnetic data for the southern Holy Cross Mountains. Acta Geologica Polonica 58, 1-12.

Szaniawski, R., Lewandowski, M., 2010. Palaeomagnetic age constraints indicate post-Variscan orgin of massive breccia in Wietrznia Quarry (Holy Cross Mountains, Central Poland). Geological Quarterly 53, 357-362.

Szaniawski, R., Konon, A., Grabowski, J., Schnabl, P., 2011. Palaeomagnetic age constraints on folding and faulting events in Devonian carbonates of the Kielce Fold Zone (southern Holy Cross Mountains, Central Poland). Geological Quarterly 55, 223-234.

Tauxe, L., Watson, G.S., 1994. The fold test: an eigen analysis approach. Earth and Planetary Science Letters, 122, 331-341.

Teller, L., 1997. The subsurface Silurian in the East European Platform . In: Urbanek, A., Teller, L. (Eds.) , Silurian graptolite faunas in the East European Platform : Stratigraphy and Evolution. Palaeontologia Polonica 56, 7-21.

Woodcock, N. H., Rickards, R. B. 2006. Geological notes and local details for 1:10 000 sheet SD 69 NE (Westerdale), and parts of sheets SD 69 NW (Howgill), SD 69 SW (Firbank) and SD 69 SE (Sedbergh). British Geological Survey, Geology and Landscape Northern Britain Programme, Internal Report IR/03/090 1-53

Zwing, A., 2003. Causes and mechanisms of remagnetisation in Palaeozoic sedimentary rocks- a multidisciplinary approach. PhD thesis, LMU Munchen, (http://edoc. ub.unimuenchen.de/archive/00001578/). 